\title{
EUROPOLITY
}

\section{Continuity and Change in European Governance}

The Department of International Relations and European Integration The National University for Political Studies and Public Administration 


\section{EUROPOLITY - Continuity and Change in European Governance}

Europolity - Continuity and Change in European Governance is a biannual peer reviewed open access journal published under the aegis of the Department of International Relations and European Integration of the National University of Political Studies and Public Administration, through the Centre of European Studies (CES). Designed in 2007, it was primarily addressed to young researchers, giving them the opportunity to publish academic papers and opinion articles on topics related to the study of the European Union. Nowadays, edited by CES, Europolity is mainly oriented towards multi-disciplinary scholarly work in European Studies, supporting therefore relevant theoretical, methodological and empirical analyses connected to this field and coming from EU Studies or International Relations, but also from International (Political) Economy, Law, Sociological Studies, Cultural Studies, etc. Journal articles and book reviews are therefore dedicated to in-depth innovative investigations of the European polity, politics and policies, stimulating debate and facilitating academic networking of scholars interested in these topics. 
THE DEPARTMENT OF INTERNATIONAL RELATIONS AND EUROPEAN INTEGRATION

THE NATIONAL UNIVERSITY OF POLITICAL STUDIES AND PUBLIC ADM INISTRATION

\title{
EUROPOLITY
}

Continuity and Change in European G overnance

\author{
Vol. 11, no. 2, 2017
}

\section{Centre for European Studies}


Founding Director: Iordan Gh. Bărbulescu

Director: George Anglițoiu

Editor-in-Chief: Ana Maria Costea

Executive editors: Mihai Cercel, Radu Ungureanu

Book review editor: Radu Cucută

Section editors:

- $\quad$ European Studies: Ioana Dodi

- $\quad$ Evaluation: Ioana Melenciuc

- International Relations: Mihaela Pădureanu

Editorial Board:

Clayton Daniel Allen (Bush School of Government and Public Service, Texas A\&M University)

Mihail Caradaică (National University of Political Studies and Public Administration, Bucharest)

Răzvan Călin (National University of Political Studies and Public

Administration, Bucharest)

Cristina Dogot (University of Oradea)

Radu Dudău (University of Bucharest)

Dacian Duna (Babeș-Bolyai University, Cluj-Napoca)

Iulian Fota (,Mihai Viteazul" National Intelligence Academy)

Mihai Murariu (West University of Timisoara)

Editorial Staff

Graphic designer: Alexandra Prelipceanu

Scientific Board:

Nader Ahmadi (University of Gävle)

Enrique Banus (International University of Catalonia, Barcelona)

Cezar Birzea (National University of Political Studies and Public

Administration, Bucharest)

Mircea Brie (University of Oradea)

Daniel J. Caron (École nationale d'administration publique, Quebec)

Hector Casanueva Ojeda (Latin American Centre for Relations with Europe, Santiago de Chile)

Daniel Dăianu (Romanian Academy)

Cristina Dallara (University of Bologna)

Kozma Gabor (University of Debrecen)

Ioan Horga (University of Oradea)

Adrian Ivan (Babeș-Bolyai University, Cluj-Napoca)

Philippe Le Guen (Director - Association and Home of J. Monnet, Paris)

Ioannis Lianos (University College London)

Francisco Aldecoa Luzzaraga (Complutense University of Madrid)

Andreea Iancu (Alexandru Ioan Cuza University of Iasi)

Robert Tyler Jones (Bush School of Government and Public Service, Texas A\&M University)

Juan Andrés Ligero Lasa (Charles III University of Madrid)

Gabriel Micu (National University of Political Studies and Public Administration, Bucharest)

Gabriela Mihailovici (National Bank of Romania)

Mihai Bogdan Popescu (National University of Political Studies and Public Administration, Bucharest)

Adrian Popoviciu (University of Oradea)

Constantin Țoca (University of Oradea)

Bogdan Munteanu (National University of Political Studies and Public Administration, Bucharest)
Józef Niżnik (Institute of Philosophy and Sociology - Polish Academy of Sciences, Warsaw)

Ioan Mircea Pașcu (European Parliament, Brussels/Strasbourg)

Nicolae Păun (Babes-Bolyai University, Cluj-Napoca)

Beatriz Peluffo (Central University of Chile, Santiago de Chile)

George Poede (Alexandru Ioan Cuza University of Iaşi)

Joaquin Roy (University of Miami)

Andrzej Rychard (Institute of Philosophy and Sociology - Polish

Academy of Sciences, Warsaw)

Jonathan Scheele (St. Anthony's College, Oxford University)

Vasile Secăreș (Romanian Banking Institute)

Stefan Sjöberg (University of Gävle)

George Voicu (National University of Political Studies and Public

Administration, Bucharest)

Peter Volten (University of Groningen)

Laurence Whitehead (Nuffield College, Oxford University)

Wichard Woyke (University of Muenster)

EUROPOLITY - Continuity and Change in European Governance is edited by the Department of International Relations and European Integration (DRIIE) National University of Political Studies and Public Administration (SNSPA), through the Centre for European Studies

Address: 30A Expozitiei Bvd., Sector 1, Bucharest, Romania

E-mail: contact@europolity.eu. Web: www.europolity.eu

EUROPOLITY - Continuity and Change in European Governance is published by C.H. Beck (Romania) Publishing House

Address: 2 Nutu Ion Str., Sector 5, Bucharest, Romania

Phone: 0040 21.410.08.47. Fax: 0040 21.410.08.48

E-mail: comenzi@beck.ro. Web: www.beck.ro

Copyright $\odot 2017$ C.H. Beck (Romania) Publishing House; Centre for European Studies - DRIIE, SNSPA

All rights reserved. No part of this publication may be reproduced, stored in a retrieval system, or transmitted in any form or by any means, without prior written permission of the publisher or the editor.

ISSN (print) 2344-2247; ISSN (online) 2344-2255; ISSN-L 2344-2247

The Journal is indexed in ESCI, Index Copernicus Journals Master List, CEEOL, DOAJ, EBSCO, HeinOnline, RePEc, SSRN, and Ulrichsweb.

*** The views expressed in the articles, reviews and other contributions which appear in the journal are the responsibility of the individual authors and do not reflect the views of either the publisher or the editor. 


\section{CONTENTS}

AFTER BREXIT: THE CHALLENGES OF HIGHER EDUCATION IN EUROPE AND LATIN AMERICA

Fernando GALVAN

5

INTERPLAY OF SOCIAL REPRESENTATIONS, TRAUMA AND VICTIMIZATION IN INTRACTABLE CONFLICTS: THE CASE OF THE CYPRUS CONFLICT

Cristiana Lavinia BĂDULESCU

THE CROSS-BORDER COOPERATION BETWEEN ROMANIA AND UKRAINE IN THE CONTEXT OF THE EASTERN PARTNERSHIP (EPP) AND ASSOCIATION AGREEMENTS (AA)

Mircea BRIE

AGENT-CHANGE RELATION: EU MEMBERSHIP AND THE NEW DYNAMICS OF ROMANIAN PUBLIC ADMINISTRATION

Cristina-Maria DOGOT

GEOPOLITICS AT THE EASTERN BORDERS OF THE EUROPEAN UNION: EASTERN EUROPE BETWEEN THE EU AND RUSSIA

Dacian DUNA

EUROPEAN UNION SUPPORT AND TRANSITIONAL JUSTICE PROCESSES IN KOSOVO

Remzije ISTREFI

RUSSIAN - UKRAINIAN CONFLICT REVISITED: TOWARDS REGIME CHANGE IN RUSSIA?

Ryszard M. MACHNIKOWSKI

BOOK REVIEW

Fawaz A. Gerges, 2016. ISIS. A History, Princeton University Press, USA, 368 pages, ISBN: 978-0-691-17000-8

Mihai MURARIU 187

Call for papers - Vol. 12, no. 1, 2018 


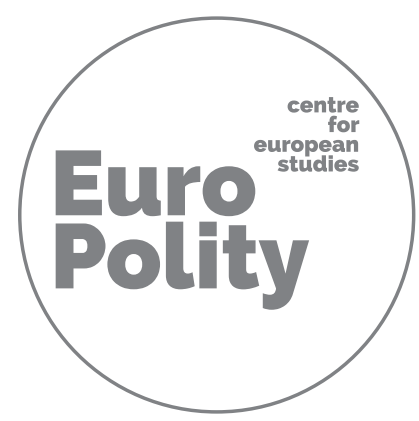




\title{
AFTER BREXIT: THE CHALLENGES OF HIGHER EDUCATION IN EUROPE AND LATIN AMERICA
}

\author{
Fernando G alván 1 \\ University of Alcalá \\ Madrid/Spain \\ rector@uah.es
}

\begin{abstract}
A bstract
This paper presents a discussion of the main issues involved in the Brexit decision and negotiations for Higher Education, Science, Technology and Innovation both for the EU and the UK. It analyses the challenges posed by the results of the British referendum in 2016, providing current data and figures about students, faculty, research and funding and how it might affect the future relations between the EU countries and the UK after 2019. In view of the new avenues opened after Brexit for higher education, research and innovation in the $\mathrm{UK}$ and the EU, it also addresses the current conditions and challenges of cooperation between Europe and Latin America and the Caribbean. The author, who is President of a birregional academic initiative, the Academic Permanent Forum for Latin America, Caribbean and the European Union (FAP ALC-UE), offers a summary of the main steps taken by this organization since 2012, which have led to the presentation of proposals to the political summits of Heads of State and Government of CELAC and the EU in Santiago de Chile (2013) and Brussels (2015). This is a grass-root movement constituted by members of universities and research centres in both regions whose main purpose is to put
\end{abstract}

${ }^{1}$ Fernando Galván is Rector of the University of Alcalá (Madrid, Spain) and President of the Academic Permanent Forum for Latin America, Caribbean and European Union (FAP ALC-UE) 
forward proposals for the establishment of a Common Birregional Area for Higher Education, Science, Technology and Innovation.

\section{Keywords}

Europe, Higher Education, Latin America,

One of the key issues in Europe at present, with larger implications globally, is the decision adopted in the referendum on 23rd June 2016 by the United Kingdom to leave the European Union, generally known as "Brexit", a decision taken by $51.9 \%$ of votes in favour of leaving, with $48.1 \%$ voting in favour of remaining. Even though the decision was taken more than a year ago, with a high $71.8 \%$ of turnout, and more than 30 million people voting, for months later the debate has gone on about what the real implications of the referendum would be like, and whether that result might be amended by Parliament or another referendum on the same subject.

But now the situation is particularly delicate after the British Government sent notification to the European Union on 29th March 2017 to withdraw under Article 50 of the Treaty on European Union. As is well known, a snap general election was called by Prime Minister Theresa May for 8th June 2017, with the purpose of gaining a clear majority in Parliament which would eventually give her more strength to implement the decision adopted in the referendum. The results of the election however were not those expected by PM May, so that the relations between $\mathrm{UK}$ and the EU at the time this paper is going to press (November 2017) are very uncertain. I wish to deal here only with some of the implications of the Brexit in the area of higher education, research, science, technology and innovation, and not only in the UK but in Europe at large, and the world globally.

The preoccupation among higher education institutions in the UK and Europe is obvious. Our colleagues in higher education across Europe, and even beyond Europe, have shared that concern in the previous months. I cannot mention in this paper all the aspects involved, but let me at least draw the reader's attention upon an interesting document issued by the House of Commons Education 
Committee, entitled Exiting the EU: Challenges and Opportunities for Higher Education, which is the ninth report of session 2016-17 of that Committee, published on 25th April 2017, which contains relevant information and data, as well as recommendations for the negotiation process of the British withdrawal from the EU. I do not wish to forget either the campaign launched by young people in the UK entitled "Undivided", which is also a good evidence of the interest among our youth in their future and the future of coming generations.

The British Council also launched this year a campaign in Europe in order to discuss this situation engaging British and European partners, an initiative known as "the British Council EU-UK Culture and Education Series"; two meetings took place, one in Berlin, on 15th-16th February; and the other in Madrid, on 24th-25th April. The reports of those two meetings are testament to the common concerns in the UK and EU about higher education, research, science and culture, about mobility of students and staff, about an open labour market for researchers, the need to consider this during the Brexit negotiations as a sort of excéption culturelle to be applied to higher education, culture, research and innovation, the perspectives about future funding for research, the immigration issue when applied to scholars, etc.

Students are a major preoccupation for all of us. According to that House of Commons report, in the previous academic year, 2015-16, there were 2.28 million students at UK universities; $5.6 \%$ of those students were from the EU, and $13.6 \%$ from non-EU countries (House of Commons Education Committee 2017, 8), i.e. almost $20 \%$ of the higher education population of the UK come from abroad, nearly 450,000 students. Hard measures against the entry in the UK of those students in the future might affect very negatively the quality and viability of many British universities, so all parties concerned are now asking the Government (I quote from that parliamentary report) to "guarantee home rate fees and access to tuition fee loans for EU undergraduate students starting in England in the academic year 2018/19 well in advance of the early deadline for course applications. The status of postgraduate students should also be clarified" (House of Commons Education Committee 2017, 10). If the Erasmus + programme cannot be applied or is substantially weakened, due to the withdrawal of funding by Britain, many thousands of students from the EU would have no access to free tuition fees at 
British universities through the current MoUs and exchange agreements, but also, of course, several thousands of British students would not be able to pursue their studies in EU countries.

In the academic year 2013/14 the outgoing student mobility from the UK via Erasmus was 15,610, a figure that has been increasing year by year in recent times. The same applies to academic staff. British students will be affected particularly in the fields of Clinical Medicine, French Studies, Spanish Studies, Business Studies and Other European Languages and Studies (Universities UK and UK HE International Unit 2016, 16-17), which means they will not have the opportunity to get the global training and competencies demanded by the labour market.

Moreover, foreign students are an important contribution to UK economy. According to data compiled by Universities UK, non-UK students generate an estimated 11 billion pounds for the economy. EU students alone "contributed 3.7 billion pounds for the UK economy and supported over 34,000 jobs in all corners of the country" (Universities UK and UK HE International Unit 2016, 28). The region most affected if those EU students don't have access to the UK universities would be London, because London receives 2,500 million pounds from non-UK students, and a large proportion of those are EU students.

But the preoccupation is not only related to students and future graduates, but is also addressed to teaching and scientific staff. The mobility of UK teachers and researchers will be seriously impeded, if EU professionals at the same level will not be allowed free movement in the UK. That would be a very serious blow to UK research. According to figures and statistics provided by Universities UK, in the year $201246.3 \%$ of UK research publications involved an international collaboration, i.e. were internationally co-authored, and "since 2003 the rate has grown faster than its key competitors except the USA, where only $30 \%$ of publications are internationally co-authored" (Universities UK and UK HE International Unit $2016,21)$. Data show that the world average for that year (2012) was $18 \%$ of coauthored papers (the UK had 46.3\%) and the growth rate between 2003-2012 was $8 \%$ (the UK's was $29.5 \%$ ).

Many of those international collaborations come precisely from EU countries. According to the same source (Universities UK and UK HE International 2016, 
$20)$, in the period 2008-2012 the UK's top 10 collaboration partners, by number of co-authored papers, are: 1) United States (89,579); 2) Germany $(45,250) ; 3)$ France $(33,454) ; 4)$ Italy $(27,789) ; 5)$ Australia $(24,403) ; 6)$ Netherlands $(24,147) ; 7)$ Spain $(23,258) ; 8)$ China $(22,813) ; 9)$ Canada $(21,860)$; and 10) Switzerland $(16,589)$. If we consider not the top 10, but the top 20 partner countries, the result is that 13 of those 20 countries are EU member states.

These figures can easily explain the turmoil that thousands of researchers and scientists, in all fields of knowledge, are now going through in the UK, but also in the EU. Although money is not all, it is certainly an essential component for the development and innovation of universities. Let us see only a few more details. As of April 2016, the projects coordinated by the UK under the EU Horizon 2020 programme were close to 1,500, the largest figure of all EU countries, being followed by Spain, with about 900, and Germany slightly lower (Universities UK and UK HE International Unit 2016, 26). Contrary to the Brexiters' message and complaint about the UK money which goes to fund the $\mathrm{EU}$, and according to the British parliamentary report mentioned earlier, "from 2007 to 2013, the UK contributed €5.4 billion to the EU for research, development and innovation; over the same time, the UK received $€ 8.8$ billion [more than 3 billion more than its contribution to EU funding]. $€ 6.9$ billion out of the $€ 8.8$ billion received was from Horizon 2020's predecessor, the Framew ork 7 Programme. UK universities were the most successful recipients of Framew ork 7 with a 71\% share" (House of Commons Education Committee 2017, 18).

The gross domestic expenditure on research and development funded from abroad in 2014 was nearly 19\% [18.9\%] in the UK, the largest percentage by far from all other countries in the world: Austria had 15\%; the Netherlands $12.5 \%$; Canada 6\%; Germany 5\%; the US 4.5\%; South Korea 0.7\%; and Japan $0.4 \%$ (Universities UK and UK HE International Unit 2016, 27). It is not difficult to imagine the strong preoccupation among British researchers and institutions if that international funding -a large part of which comes from the EU- will no longer go to the UK in the near future, after 2019, when the final withdrawal from the EU takes place.

Data also show that the area of the world which sends fewer students to the UK is South America. UK universities receive nearly 450,000 foreign students every 
year. Most of them come from the EU, China, India and other countries in Asia; also substantial numbers of students come from Africa, the Middle East and North America. Curiously enough, only slightly more than 2,000 students from South America go to UK universities, which is just $0.5 \%$ of the total number of foreign students at UK universities. (Universities UK and UK HE International Unit 2016, 14)

I believe that even if the EU and the UK reach a good agreement for the period after 2019, even if the UK manages to keep the high population of Asian and African students (which now seems a difficult issue, because international students would probably be part of the net migration target, if a hard Brexit takes place, according to the British Government policies in this sector), what remains a subject worthy of further exploration is South America, or Latin America and the Caribbean at large.

Paradoxically, the population of South America, according to 2015 statistics, is over 400 million people. If the Caribbean, Central America and Mexico are added, the figure will obviously increase to over 550 million or close to 600 million people. Even if the number of Latin American students who come to some European countries, like Spain, Portugal, France, Germany and Italy, is higher than that which goes to the UK, it is evident that there is still a lack of mobility in higher education and research between both regions. This is precisely an area in which the negative effects of Brexit both in the UK and in the EU could be counterbalanced if the educational, scientific and cultural relations between Latin America and Europe were stronger.

In my capacity as President of the Academic Permanent Forum for Latin America, Caribbean and European Union I would like to now focus on this field, which I consider to be a sort of wishing-well of opportunities and positive expectations if we know how to address the main issues of cooperation in higher education between the two regions. Let me thus provide in the following pages some information, reflections and thoughts about what we have been doing in the last five or six years and what we can modestly contribute, as an academic movement, to the progress of higher education in the two regions.

It is self-evident that the strategic association between the European region and the Latin American and Caribbean region must be based on firm academic 
grounds. For the preservation and fostering of peace, freedom, democracy, human rights and culture in its diverse manifestations, the direct involvement of the academic world is necessary, essential, because education is the basis for the advancement of knowledge, the creation of science, technology and innovation. Issues closely connected to those are of course economic progress, sustainable development, the reduction of the social gap and gender equality.

Thus a movement has been growing in numerous international conferences in Europe and America, for more than fifteen years now, in favour of the constitution of a forum which would allow for the exchange of experiences in higher education, research, technology and innovation, for bi-regional and intraregional associations which would provide academic and research programmes, mobility of academic staff and students, and the accreditation and recognition of studies, degrees and diplomas. The experience accumulated by European programmes such as Erasmus, Erasmus Mundus, Alfa, or the Framework Programmes for Science and Technology and Horizon 2020 are clear examples of success within Europe, which could be used as models to orient new programmes addressed to a bi-regional level.

The Strategic Association of Latin America and the Caribbean and the European Union, convened in the First Summit Meeting of Heads of State and Government, which gathered sixty countries and was held in Rio de Janeiro in 1999, declared higher education, science and technology as a priority. That was ratified in the following summits, with new and important decisions concerning the establishment of a Euro-Latin American Area of Knowledge and the JIRI (Joint Initiative for Research and Innovation). The conference of ministers of education of the two regions held in Paris in November 2000 emphasised the need to build up structures or frames of activity in order to achieve those objectives.

In June 2012 a significant number of higher education institutions of both regions met for the first time in Paris at the Institut des Amériques and held a seminar with the purpose of opening up a forum for reflection and debate on those issues. That first seminar was followed, in October 2012, by another seminar in Lima, at the "Colegio de Ingenieros del Perú", also sponsored by two organisations of Peruvian universities. Other international organisations soon 
joined this initiative, like the EU-LAC Foundation (established two years before) and its partners, i.e. the Global Foundation for Democracy and Development (FUNGLODE) of the Dominican Republic, the Lombardy region, the Institut des Amériques and the United Nations Economic Commission for Latin America and the Caribbean (ECLAC, or the acronym CEPAL for its initials in Spanish: "Comisión Económica para América Latina y el Caribe"). Those two first seminars in 2012 paved the way for the First Academic Summit, which took place in Santiago de Chile on 22nd-23rd January 2013, coinciding with the 7th Summit of European and Latin-American Heads of State and Government (or First CELAC-EU Summit of Heads of State and Government), following the example of parallel meetings organised a few years earlier by other sectors of civil society, such as NGOs, or the Business Summit (established in the Madrid Summit in 2000).

Those two meetings in 2012 were initially called by a group of institutions and academics from Chile and France (the Chilean Centro Latinoamericano para las Relaciones con Europa (CELARE) "Latin American Centre for the Relations with Europe", and the French Institut des Amériques) under the name of "Area for the Association of Latin America and the Caribbean and the European Union for Higher Education, Science, Technology and Innovation", but many other academics from numerous countries in the two regions soon joined the initiative, and as a consequence about 100 participants from more than 50 academic institutions from both regions contributed to each of those seminars.

The Academic Summit in Santiago de Chile in January 2013 was a great success. Relevant political authorities and academics of both regions took part in it: Benita Ferrero-Waldner, then President of the EU-LAC Foundation; José Ignacio Salafranca, President of the Euro-Latin American Parliamentary Assembly (EUROLAT); Simone Bonnafous, Director General of Higher Education of the French Government; Alfredo Moreno, Minister of Foreign Affairs of the Government of Chile; Alicia Bárcena, Executive Secretary of the Economic Commission for Latin America and the Caribbean (CEPAL); Leonel Fernández, President of FUNGLODE and former President of the Dominican Republic (now the current President of the EU-LAC Foundation), dozens of Presidents and Rectors of Latin American and European Universities and of course a huge 
number of academics interested in the educational cooperation between the two regions.

In total, some 650 academics representing 220 institutions from both regions participated in the debates and elaborated a Declaration which was presented to the Summit of Heads of State and Government held in Santiago on 26th-27th January, through a special meeting with the Ministers of Foreign Affairs and authorities of the European Union. The Declaration of the Summit of Heads of State and Government ratified again the importance of the development of joint actions in higher education, science, technology and innovation and took note of this first Academic Summit.

The Declaration of that first Academic Summit, with all the contributions made by academics, was published in a book comprising nearly 500 pages, which was an excellent testimony to the diversity and the joint efforts of so many institutions involved. I cannot even attempt to summarise all those papers of course; but the book is available on line (details are provided in the final bibliographical references).

One of the most relevant decisions taken in Santiago was also to give this initiative a more formal structure, in order to improve the organisation; so the Academic Permanent Forum was established, with an Executive Secretariat constituted by representatives of the Institut des Amériques and CELARE, and they started the elaboration of an Action Plan for the organisation of the Second Academic Summit.

During 2014 two other seminars were held, preparing the Second Academic Summit, to be held in Brussels in June 2015. The first seminar took place at the Institute of Latin American Studies (ISLA) of the National School of Political Studies and Public Administration (SNSPA) in Bucharest, on 26th-27th May 2014; and the second one at the University of Guadalajara, Mexico, on 25th-26th November. Both meetings were very well attended, with more participants than the previous seminars in Paris and Lima, and prepared the works for the Academic Summit in Brussels in June 2015; two books were published gathering the main papers and conclusions achieved in the debates. Before that Academic Summit another meeting was organised at the University of Alcalá (Spain) on 
13th-14th April 2015 and defined more closely the strategy for the organisation of the Summit.

During 2014 and 2015 the Academic Permanent Forum was getting stronger and reinforced its structure, due particularly to the incorporation to the Forum and the Seminars of more institutions and academics from both regions. In addition to the Executive Secretariat, four Permanent Reflection Groups were also created in the Guadalajara seminar, so as to coordinate the papers presented in seminars and Academic Summits, which reflect the four areas defined as priorities in the Santiago Academic Summit. Although some of the coordinators of those Groups have changed in the last two years, the current distribution of the Permanent Reflection Groups and their Chairs is as follows:

1. Higher Education, coordinated by Francisco Aldecoa (Complutense University, Madrid) and Alan Fairlie (Catholic University of Peru). This group works in the integration of the higher education systems in the two regions, including intra-regional Latin American and Caribbean convergence and the establishment of independent regional agencies for accreditation which develop models of recognition of credits and studies, among other measures, in order to foster mobility, doubles degrees, multidisciplinary programmes, e-learning, education and intercultural relations, higher education technical training, etc.

2. Science, Technology and Innovation, coordinated by Kajsa K. Ekroos (University of Helsinki) and Carlos Alberto Vigil (Cuba). The objectives of this group can be summarised in the institutionalisation of exchanges for research and the creation of a bi-regional agency of intellectual property, as well as the establishment of a bi-regional fund for the development of joint projects of research and innovation, mobility programmes for researchers and scientists, research and innovation for sustainable development, research infrastructures, etc.

3. Links with Society, coordinated by Celso Garrido (Metropolitan Autonomous University of Mexico) and Florence Pinot (ESCP Europe/CERALE, France). This group is mainly concerned with the development of proposals for a stronger interaction between universities and the productive sector, so as to promote research, $\mathrm{PhD}$ dissertations 
and projects funded by business and other firms, as well as entrepreneurship and innovation, with strong connections with society and industry.

4. Links with Public Policies, coordinated by Iordan Barbulescu (ISLA, National School of Political Studies and Public Administration, Romania) and Marco Moreno (Central University of Chile). This fourth group addresses the role our universities can play in the development of public policies in our respective countries and regions, such as the internationalisation of our institutions, or the implementation of policies of sustainability, or sustainable education, sexual and gender equality, or policies of healthcare and human rights related to the SDGs (Sustainable Development Goals) of the United Nations Agenda 2030.

The Brussels Academic Summit on 8th-9th June 2015 was very well attended, with more than 500 participants. A book of more than 600 pages was also published, collecting the main papers presented in Brussels. As it had happened in Santiago two years before, official support was given to the Forum and the Academic Summit by authorities in both regions: the Vice President of the European Parliament, in his capacity as Co-President of the Euro-Latin American Parliamentary Assembly, Mr Ramón Jáuregui; the European Commissioner for Science and Technology, Mr Carlos Moedas; the Secretary for Higher Education and Research of the Government of Ecuador, then having the pro-tempore Presidency of CELAC, Mr. René Ramírez; as well as other relevant personalities who had been present in Santiago, like the President of the EU-LAC Foundation, the Executive Secretary of CEPAL, etc.

The Declaration of this Academic Summit was presented to the CELAC-EU Summit Meeting of Heads of State and Government by the Presidents/Rectors of two universities: the University of Guadalajara Mexico and the National School of Political Studies and Public Administration of Bucharest, and it was significantly recognised by the official Declaration of the Summit, more particularly in chapter 9 of its Action Plan, together with other initiatives such as the JIRI and the Summit of Presidents of the Councils of Rectors of both regions. New steps have taken place since the Brussels Summit. On 1st February 2016 a meeting was convened in Lisbon, at the University Institute of Lisbon (ISCTE), 
for the constitution of a renovated Bi-Regional Academic Council (CAB) and a stronger Executive Secretariat, with the presence, in addition to the representatives of CELARE and the Institut des Amériques, of two other institutions: the University of Guadalajara and the National School of Political Studies and Public Administration of Bucharest, represented by Professor Iordan Barbulescu, President of its Senate. About 100 representatives also gathered for this Lisbon meeting in February 2016 and they approved the new Statutes of the Forum, thus formalising the five units of the Academic Permanent Forum, i.e. the Presidency, the Executive Secretariat, the Bi-Regional Academic Council, the four Permanent Reflection Groups, and the Bi-Regional Advisory Board. Detailed information about this can be found on our website (www.fap-alc-ue.com), but let me add that effort is continuously being made to maintain and reinforce the plurality and diversity of our two regions, as well as the high level of representation of higher education institutions in Europe and Latin America and the Caribbean.

The 3rd Academic Summit was due to take place in October 2017 in El Salvador, parallel as on previous occasions to the corresponding CELAC-EU Summit of Heads of State and Government, but this latter Summit has been postponed sine die, and we are now waiting for a final decision about dates and location. However, two semi-annual seminars were organised in 2016 in preparation for this Academic Summit; the first one on 21st-22nd June 2016, in Santo Domingo, Dominican Republic, organised jointly by the Academic Permanent Forum and the Dominican Government and higher education institutions in that country, such as the Autonomous University of Santo Domingo (UASD); the second seminar took place at the University of Stockholm, on 6th-7th October 2016, organised by the European Institute of International Studies, and sponsored by other organisations like the Swedish Ministry of Foreign Affairs, the Embassies of several Latin American countries in Stockholm, the governments of the Nordic countries, as well as of course EU-LAC Foundation, CELARE, and ISLA (Romania), among some others.

Another preparatory meeting of the Bi-Regional Academic Council was held on 5th-6th May 2017 at the University of Salamanca, and further discussed the agenda for the planned Academic Summit in El Salvador. Progress is now being 
made as work continues through the Permanent Reflection Groups. We expect to hold in 2018 the Third Academic Summit, where specific proposals will be discussed in order to be presented to the Ministers and the Heads of State and Government.

As I have tried to show, Latin American and Caribbean (LAC) education is one of the great global challenges we need to face, not only versus the Brexit and within the European Union, but also at an intra-regional level, in Latin America itself. As higher education is concerned, both in the UK and the EU, Latin America is still -and to a large extent- an almost terra incognita. Millions of LAC higher education students and staff, scientists and technologists are eager to participate in mobility programmes and in research collaboration with the EU and the UK.

The current aggressive US policy towards its southern neighbours, of which the Mexican wall is just one example, can surely help in making the EU (but also the UK) a haven for those LAC students and scholars who wish to contribute to a global world. Our students and staff in the EU would also benefit from those exchanges, and even, if I may say so, more easily than in the EU itself, as there are fewer language differences within the American subcontinent than in the EU, and that would certainly facilitate communication and academic exchanges.

If we have succeeded in our mobility programmes, in our accreditation and recognition of credits and diplomas within the EU, where twenty-four official languages coexist, why cannot we do so with Latin America, with fewer languages? It is our duty as academics involved in higher education, science, technology and innovation to work together in order to foster those alliances and to promote the necessary legal and structural changes in our institutions.

\section{REFERENCES}

- $\quad$ Ghymers, Christian and Patricio Leiva, eds. 2016. Construyendo el Espacio A cadémico Común de Educación Superior, Ciencia, Tecnología e Innovación para la A sociación Estratégica Birregional. Brussels: IRELAC. https://fapalcuecab2017.files.wordpress.com/2017/04/libro-bruselas.pdf 
- House of Commons Education Committee. 2017. Exiting the EU: Challenges and O pportunities for Higher Education. Ninth Report of Session 2016-17. HC 683. Published on 25 April 2017 by authority of the House of Commons. www.parliament.uk/education-committee

- Leiva, Patricio, ed. 2013. Hacia un Espacio Eurolatinoamericano y Caribeño para la Educación Superior, Ciencia, Tecnología e Innovación. Santiago de Chile: JC Sáez Editor. https://fapalcuecab2017.files.wordpress.com/2017/04/librosantiago.pdf

- $\quad$ Universities UK and UK International HE Unit. 2016. International H igher Education in Facts and Figures. June 2016. London: The UK HE International Unit. www.international.ac.uk 


\title{
INTERPLAY OF SOCIAL REPRESENTATIONS, TRAUMA AND VICTIMIZATION IN INTRACTABLE CONFLICTS: THE CASE OF THE CYPRUS CONFLICT
}

\author{
Cristiana Lavinia Bădulescu \\ The National University of Political Studies and Public Administration \\ Bucharest, Romania \\ lavinia_Ip@yahoo.com
}

\begin{abstract}
A bstract
Intractable conflicts are conflicts that persist over a long period of time, resist various attempts of resolution, and present sporadic episodes of violence juxtaposed with periods of relative calm. Also, they contain a large share of psychosocial factors which lend to their uniqueness while also adding to their complexity. The Cypriot conflict is such a conflict. It has been on the agenda of the international community for over four decades, it has gone through a number of occasional violent episodes that fluctuated in frequency and intensity, and has resisted various peace mediation efforts. As a result, the conflicting parties remained locked in an adversarial relationship and fixed in terms of fundamental grievances. This paper aims to explore the interplay of social representations, trauma and victimization in the Cyprus conflict, and their implications on the prospects for its further settlement. Specifically, using discourse analysis as a research method, this paper analyses both the GreekCypriot and Turkish-Cypriot official discourse during 1983-2012 in order to see how the two parties represent the conflict, and whether past trauma and victimization influence their social representations. Close attention to the key themes emerging from the two parties' official discourse helps to deepen understanding of the role and effect social representations, trauma and victimization play in the perpetuation of the Cyprus conflict.
\end{abstract}




\section{Keywords}

Conflict resolution, Cyprus, intractable conflicts, social representations, trauma, victimization

\section{INTRODUCTION}

Intractable conflicts are known under different labels such as deep-rooted conflicts (Burton 1987), enduring rivalries (Goertz and Diehl 1993), protracted conflicts (Azar 1990), malignant conflicts (Deutsch 1985). Generally, intractable conflicts are defined as being conflicts persisting over a long period of time, resisting various attempts at resolution, and presenting sporadic episodes of violence juxtaposed with periods of relative calm (Coleman 2006). The conflicts between Israel and Palestine, Armenia and Azerbaijan over Nagorno-Karabakh, Greek Cypriots and Turkish Cypriots, Georgia and the breakaway regions of Abkhazia and South Ossetia, India and Pakistan over Kashmir region, are cases in point.

In the literature, intractable conflicts are described as possessing a number of well-defined characteristics that underline their essence. For instance, Louis Kriesberg (2005, 66-68) and Daniel Bar-Tal (2007, 1432-1433) point out the following particular features that characterize intractable conflicts:

1. They are protracted. Intractable conflicts persist for a long time, at least one generation. Various and failed resolution attempts undertaken over a long period of time lead to the accumulation by the parties of animosity, grievances, negative feelings, prejudice.

2. They are perceived as irreconcilable. Parties involved in intractable conflicts perceive their goals as irreconcilable. Each side holds to its own goals, viewing them as essential for own survival; neither side sees the possibility of making concessions and resolve the conflict peacefully.

3. They involve vast investments. Parties in intractable conflicts make vast military, economic and psychological investments which later have repercussions on the resolution attempts. 
4. They are violent. Intractable conflicts involve outbreaks of violence which alternate in intensity and frequency, are associated with destruction, grave human rights violations, atrocities, refugees and internally displaced persons (IDPs), and cause traumatic consequences for the members of the societies involved in the conflict.

5. They are perceived as being of zero sum nature. Each party considers any gain recorded by its opponent as its own loss, and any loss suffered by its opponent as its own gain.

6. They are total. Intractable conflicts are perceived by the parties concerned as involving needs and values that are fundamental for their existence or survival. Therefore, intractable conflicts address a multitude of issues such as territory, resources, identity, economy, religion, etc.

7. They are central. Members of the societies involved in an intractable conflict are preoccupied constantly and continuously with it. This preoccupation reflects its centrality both in the lives of the individual group members and in public life, for instance in the media or the speeches of the leaders. The conflict is at the top of the public agenda and salient in debates.

Hence, this type of protracted, violent and destructive conflicts has serious implications for the societies involved, both at micro-, mid-, macro-structural level. For instance, at micro level, individuals present psychological wounds and a deep sense of injustice, victimization, humiliation; at mid-level, the groups and the institutions to which individuals belong operate on a dysfunctional pattern; at macro level, the concerned societies are refractory to any signal of change, construction in the meaning of reconciliation, of social progress (Bar-Tal, Halperin and Pliskin, 2014).

Intractable conflicts are differentiated by the presence of a large share of psychosocial factors. These factors distinguish intractable conflicts from other type of conflicts and ensure their uniqueness (Bar-Tal 2013). Psychosocial factors such as traumas, stereotypes, emotions, belief systems, victimization, historical grievances, social representations, accompany the internal, less visible sides of intractable conflicts. In this paper, I focus on social representations (about the conflict), trauma and victimization (both at the collective level). I hypothesize that past collective trauma and victimization reflected in the parties' social 
representations about the Cyprus conflict determines its perpetuation. Two research questions were used to guide and develop the hypothesis and the research design of this article:

a) What is the relationship between social representations, trauma and victimization in the Cyprus conflict?

b) What are the implications of social representations, trauma and victimization on the prospects for the further settlement of the Cyprus conflict? The paper is structured as follows. Firstly, I start with a literature review of the key concepts used in the development of the argument. Then I move to the presentation of the Cyprus conflict by providing some background and review of settlements efforts. Finally, I analyse the Greek Cypriot and Turkish Cypriot official discourse in order to see how the two sides represent the conflict, and whether past trauma and victimization influence the forming of these social representations.

\section{METHODOLOGY}

From a methodological perspective, I use discourse analysis applied on the official discourse of the Greek Cypriots (henceforth GCs) and Turkish Cypriots (henceforth TCs) leaders, and following two dimensions:

I. the representation of the conflict (how GCs and TCs represent the conflict)

II. the temporal and contextual framing of the representations about the conflict (the periods and the social contexts that GCs and TCs make reference to) The period for the analysis of the official discourse is 1983 - 2012. The time period marks the strongest efforts of the United Nations Secretary General, including the personal involvement of Pérez de Cuéllar, Boutros Boutros-Ghali, Kofi Annan and Ban Ki-moon, to negotiate and find a solution to the Cyprus conflict. In total, I have selected 14 official discourses belonging to the leaders in 
office during the selected period of study. ${ }^{1}$ These comprise of inaugural speeches, speeches at UN sessions and at various national and international meetings, official letters, interviews, and were collected from government websites, UN website and mass-media.

\section{LITERATURE REVIEW}

Intractable conflicts are prolonged conflicts leaving room for the infiltration of psychological wounds, grievances, and animosity between the members of the societies involved. As mentioned above, they involve vicious cycles of violence and a large range of psychosocial factors that contributes to their uniqueness. In this section, I define and explain key concepts such as social representations, trauma and victimization, and interrelated psychosocial factors with special significance in intractable conflicts.

Social representations are "a set of concepts, statements and explanations originating in daily life in the course of interindividual communications. They are the equivalent in our society, of the myths and belief systems in traditional societies; they might even be said, the contemporary version of common sense" (Moscovici 1981, 181 quoted in BarTal 2014, 5.2-5.3). According to this definition, social representations are collectively shared concepts and images constructed in language and infused with meaning. They constitute the constructed shared social reality of a group and are held individually by the majority of its members, as well as reflected in public discourse on an individual and collective level, for instance in mass-media (Bar-Tal 2014, 5.3).

The studies centred on social representations in the context of intractable conflicts have their basis in the field of social psychology. Scholars argue that in

${ }^{1}$ For the GC community, the leaders in office during 1983-2012 were: President Spyros Kyprianou (1983-1988), President Vassiliou (1988-1993), Glafcos Clerides (1993-1998 and 1998-2003), Tassos Papadopoulos (2003-2008) and Demetris Christofias (20082013). For the TC community, the leaders in office during 1983-2012 were: Rauf Denktash (1983-2005), Mehmet Ali Talat (2005-2010) and Dervish Eroglu (2010-2015). 
intractable conflicts, there are specific social-psychological processes, such as the formation of representations that the parties hold of each other and themselves, and of the conflict as such. These contain a strong emotional dimension and are central to intractable conflicts (Kelman 2007; Gross Stein 1996). The interactions of the social representations the parties have about the conflict they are involved in bolster distrust and dehumanization, reduce empathy and foster a win-lose mentality. Also, they are highly resistant to contradictory information or change (Fisher and Kelman 2011, 70-75). Furthermore, the parties of an intractable conflict tend to "demonize" each other (Hadjipavlou 2007, 350) and to assign its causes to the personal suffering and injustices perpetrated exclusively by the "foreign Other" (Hadjipavlou 2017, 213). Thus, the opposing party, the one perceived as being the enemy, becomes the main guilty person and solely responsible for the failure of individual tracts. Such features apply to the Cyprus conflict, as it will be shown later in the analysis.

Trauma is defined as a catastrophic stressor that was outside the range of everyday human experience (Friedman, 2016). When a traumatic experience is shared by a group of people it is called collective trauma. Collective trauma is defined as "a blow to the basic tissues of social life that damages the bonds attaching people together and impairs the prevailing sense of communality" (Erikson 1995, 184). "It consists of three primary elements: a "trauma" or wounding; the trauma is shared by a group of people, rather than an individually experienced; the trauma spans multiple generations, such that contemporary members of the affected group may experience trauma-related symptoms without having been present for the past traumatizing event(s)" (Mohatt et al. 2014, 128). It can be either man-made (war, genocide, etc.) or caused by natural disasters (tsunamis, storms, fires, etc.). My focus in this paper is on man-made collective trauma, as occur in armed conflicts for instance. When a trauma transforms itself into a collective one, the societies involved maintain the mental representation of the traumatic event together with the shared feelings of loss and pain associated with it (Volkan 1998). They internalize the collective trauma and transmit it across generations through narratives with a strong emotional content which serve to keep the trauma alive, thus reinforcing the original sense of assault and loss (Tint 2010, 247). Conflict resolution scholars point out the link between collective trauma and the 
intractability of the conflict. The violent and traumatic experiences lived in the past by the parties involved in an intractable conflict are encoded in their collective memory, which maintains a sense of a state of offence and of a past injustice throughout generations, and become part of their identity (Brewer 2011). When such traumas are engraved in identity, they end up becoming the central core of the collective narratives regarding the conflict (Wertsch and Roediger 2008; Hunter and Stewart 2015). In addition, they determine emotional problems to become just as important as the real problems that are at play such as the dispute over a specific territory (Noor et al. 2012).

The parties involved in an intractable conflict that have gone through violent traumatic experiences, either directly or indirectly, develop a sense of victimization at the collective level (Staub and Bar-Tal 2003; Bar-Tal et al. 2009). Victimization at the collective level is defined as a "mindset shared by group members that results from a perceived intentional harm with severe and lasting consequences inflicted on a collective by another group or groups, a harm that is viewed as undeserved, unjust and immoral, and one that the group was not able to prevent" (Bar-Tal et al. 2009, 238). Research points out that under the influence of suffered traumas, a group focuses only on its own sufferings and is less inclined to empathise with the victims of the other group. In the literature, this phenomenon is called "the egoism of victimization" (Mack 1990) and its often encountered in intractable conflicts.

Trauma and victimization at the collective level support antagonisms and deep divisions between the parties of an intractable conflict. As I will show later in the analysis, this is the case of the Cyprus conflict too.

\section{BACKGROUND TO THE CYPRUS CONFLICT}

The island republic of Cyprus, comprising two major ethnic communities, namely the GCs and the TCs, was under the Ottoman rule from 1571 until 1878. In 1878, Great Britain assumed control of Cyprus from the Ottomans, and became officially a British colony from 1925 until its independence in 1960. The British colonial period corresponded with the rise of nationalism in Cyprus. 
Thus, when the struggle against the British started in 1955, GCs and TCs aspired at different futures for the island: GCs favoured enosis, the union of Cyprus with Greece, while TCs envisioned taksim, the partition of the island (Papadakis, Peristianis and Welz 2006, 2).

A compromise settlement was reached in 1959 by Britain, Greece, and Turkey with the London-Zurich Agreements that granted Cyprus its independence. At independence, the constitution of Cyprus defined power-sharing arrangements between the two main groups. It required a GC president and a TC vice president, each elected by his own community and with veto power over decisions. A cabinet of ministers was composed of seven GCs and three TCs, and the same ratio was maintained in Parliament and all branches of the civil service. Simultaneously, a Treaty of Guarantee signed by Britain, Greece, and Turkey gave all three powers the right to unilaterally intervene as an extreme measure to protect the security interests of Cyprus. Additionally, a Treaty of Alliance among Cyprus, Greece, and Turkey provided 950-man Greek and 650-man Turkish soldiers to help defend the island (Anastasiou 2007, 77-78). However, the 1960 settlement did not pay attention to the two communities" "local realities and socialpsychological needs and concerns. Instead, the constitutional provisions granted in 1960 intensified and institutionalized ethnic/identity differences and gave rise to further mistrust and antagonism and an unwillingness to express loyalty to the newly established state" (Hadjipavlou-Trigeorgis and Trigeorgis 1993, 343).

The newly created republic enjoyed some fragile stability between 1960 and 1963. After President Makarios proposed amendments to the constitution, the so-called "13 Points" that favoured the majority of the GCs, relations between the two communities deteriorated and further led to inter-communal clashes in 1963 and 1964 that caused much suffering and insecurity, especially for TCs (HadjipavlouTrigeorgis and Trigeorgis 1993, 344). Several hundred people were killed, many others were wounded and kidnapped. As a consequence, the TC leadership withdrew from the government and began to administer their own affairs. Also, TCs started to geographically separate themselves from the GCs and relocate into enclaves limited to three percent of the island (Volkan 2008, 96). Some 25,000 TCs and 500 GCs had become IDPs. Furthermore, even if more than $50 \%$ of 
villages were mixed in 1891, by 1970 this figure dropped to less than 10\% (Fisher 2001, 310).

Following the crisis of 1963, the two parties and the guarantor powers (Britain, Greece, and Turkey) met in London to find a solution, but without any results. The United Nations Security Council unanimously adopted in 1964 the Resolution 186 which recommended the establishment of a United Nations Peacekeeping force mandated to "use its best efforts to prevent a recurrence of fighting and, as necessary, to contribute to the maintenance and restoration of law and order and a return to normal conditions" (Resolution 186 1964, 3). The United Nations Peacekeeping Force in Cyprus (UNFICYP) became operational on March 27, 1964 and is still operational today.

In 1974, a Greek-junta coup against Makarios took place. The fighting also spread over the TC villages and enclaves. Turkey, citing the 1960 Treaty of Guarantee as a legal basis for its action, deployed its military forces and took control of more than one-third of the island (Morelli 2015, 1). The landing of the Turkish army on the northern part of Cyprus caused widespread dislocation. About 160000 GCs were forced to flee to the south thus creating massive refugee and property problems. "Subsequent to the ceasefire, an agreement on the voluntary regrouping of populations resulted in approximately 40000 TCs moving to the north, while the approximately $10000 \mathrm{GCs}$ left in the north were pressured to go south. Thus, the events of 1974, in which several thousand people were killed or went missing, had the effect of creating two homogenous ethnic zones on the island" (Fisher 2001, 311).

In February 1975, TCs declared their government the "Turkish Federated State of Cyprus" (TFSC). In 1983, the "Turkish Republic of Northern Cyprus" (TRNC) headed by Rauf Denktash - was self-proclaimed, but failed to gain recognition by the other countries except Turkey. Since 1974, the GC and TC communities on the island have remained physically separated by a demarcation line patrolled by United Nations troops. 


\section{SETTLEMENT EFFORTS. A REVIEW OF FAILURE}

The Cyprus conflict has been on the agenda of the international community for over five decades, but has resisted various settlement efforts. In this section, I will highlight the most important moments of the peace process that took place after the 1974 coup and until 2012.

One of the first important attempts to seek a settlement to the Cyprus conflict after the 1974 coup took place on January 27, 1977, when Makarios and Denktash, the two leaders of the two communities, met for the first time in fourteen years under the United Nations auspices for high-level talks. They agreed on four guidelines for an independent bicommunal federal republic, "the primary one being that the parties were seeking an independent, non-aligned, bicommunal federal republic. The other related to the territorial division not being strictly on the basis of population ratio, the freedoms of movement, settlement, and ownership for the GC being implemented with sensitivity to TC concerns, and the central government safeguarding the unity of the state while respecting its bicommunal character" (Fisher, 2001, 314-315). The guidelines, which were thought of as forming the basis for any further peace talks, were reaffirmed in 1979 during another round of United Nations-sponsored talks between Makarios' successor, President Spyros Kyprianou, and Rauf Denktash. The parties brought a refinement of the Makarios-Denktash guidelines which is labelled as the tenpoint agreement. In addition to accepting these guidelines, this agreement demanded the immediate resettlement of the GC area of Varosha and for the ultimate demilitarization of the island (Theophanous and Christou 2014, 80).

These two high-level agreements were meant to lay the foundations for subsequent successful intercommunal talks. However, the restarting of negotiations at the beginning of the 1980s revealed obvious disagreements between the parties, especially over the priority and the sequencing of items. For instance, between 1982 and 1991, the United Nations Secretary-General, Javier Pérez de Cuéllar, made several proposals to the leaders, including a Draft Framework Agreement in 1986 which foresaw the creation of an "independent, non-aligned, bi-communal state in Cyprus, but was more detailed than the 1977 agreement in that it began to define the federal government's powers." (Security 
Council Report 2008, 7). Nevertheless, the GC did not agree with this initiative because it did not address the withdrawal of the Turkish troops, not the repatriation of Turkish settlers (Security Council Report 2008, 7). Consequently, this settlement initiative failed.

Another important attempt of the United Nations to settle the Cyprus conflict took in 1992 when the new United Nations Secretary-General, Boutros-BoutrosGhali, starting from the work of his predecessor, introduced a document entitled "Set of Ideas on an Overall Framework Agreement on Cyprus." The ideas envisaged two federated states with identical powers to safeguard the cultural identity and ensure the political equality of each community. The framework stipulated the division of powers between the federated states and the federal government, and a bicameral legislation with a federal executive to ensure representation from each community. Also, the 1960 treaties were reaffirmed, and the questions of territorial adjustment and the three freedoms (movement, settlement, and ownership) were also addressed. However, the TC side disagreed with several points of the initiative, including the questions of sovereignty, return of displaced persons and the nature of territorial arrangements (Fisher 2001, 316). Hence, the UN's proposal, yet again, failed.

The same happened with the next UN's initiative of confidence-building measures introduced in 1993, which had at its centre the reopening of the Nicosia International Airport for the benefit of both communities and the opening of the Turkish-held area of Varosha to resettlement by Greek Cypriots with UN control. Differences existed on these measures from both sides, but especially from the Turkish Cypriot one which insisted that the northern part of Varosha would have to remain within its control and that all embargoes be lifted in Northern Cyprus (Michael 2009, 134).

It was not until in 2002 when the negotiations for finding a solution to the Cyprus conflict seemed to renew hopes for a settlement with the so-called Annan Plan. This was introduced by the United Nations Secretary-General, Kofi Annan, comprised of "182 pages of main articles and finalized laws, 9,000 pages of draft laws and treaties, and was the result of more than 300 meetings" (Anastasiou 2007, 94-95). The Annan Plan proposed the creation of a bizonal, bicommunal federal republic based on the Swiss model. It called for the creation of the United Cyprus 
Republic, "an independent state in the form of an indissoluble partnership, with a federal government and two equal constituent states, the Greek Cypriot State and the Turkish Cypriot State" (Annan Plan 2004, 7). The federal government would participate in foreign and European Union relations while two politically equal component states would address much of the daily responsibilities of government in their respective communities (Morelli 2015, 3). After subsequently going through five major revisions to harmonize the demands of the parties, the final version of the Annan Plan was finalized on March 31, 2004, and submitted to simultaneous referenda on April 24, 2004. The results showed that the GC voters rejected the plan by a margin of three to one, while the TC voters accepted it by a margin of two to one (Report of the Secretary-General on his mission of good offices in Cyprus 2004, 1). After this failed attempt, the negotiations went into limbo for some time.

The official talks resumed again in 2008 when Demetris Christofias and Mehmet Ali Talat, the leaders of GC and TC communities, decided to start full-fledged negotiations under the good offices of the United Nations Secretary-General in order to find a solution to the Cyprus conflict. The talks were held on a regular basis and went well during the first 18 months until the differences in positions between the two leaders became obvious. Talat wanted to pursue negotiations on the basis of the old Annan Plan, while Christofias wanted to avoid bring it again into discussion. In January 2010, the United Nations Secretary-General, Ban Ki-moon, visited Cyprus, met with the two leaders and encouraged them to bring the negotiations to a successful conclusion. However, the talks seemed to reach a deadlock as the last formal meeting session between Christofias and Talat concluded in March 30, 2010 with no new developments (Morelli 2015, 3-4).

A new stage in the negotiation process between the GC and TC communities reopened in May 2010 under the auspices of the United Nations SecretaryGeneral's special advisor on Cyprus, Alexander Downer. Amid a lack of progress in the negotiations, Dervis Eroglu, who succeeded Mehmet Ali Talat as leader of the TC community, declared in October 2010 that as time passes, the will of the two communities to coexist was decreasing (Küçükkoşum 2010). The next period of peace talks covered several meetings between United Nations Secretary-General, Ban Ki-moon, and the two leaders, Christofias and Eroglu. 
The first one took place on November 18, 2010 in New York. In a statement after the meeting, Ban Ki-moon said that the two leaders expressed their commitment to work more quickly and decisively to find a common ground on the core issues of the dossier (Morris 2010). The second meeting between Ban Ki-moon, Christofias and Eroglu was held in Geneva on January 26, 2011, and did not bring any breakthrough in the negotiations (United Nations News Centre 2011). The third meeting between the three took place again in Geneva on July 7, 2011. This time the United Nations chief noted that progress has been too slow and that some important issues have remained unaddressed (United Nations News Centre 2011). The fourth tripartite meeting was held in New York on October 2011, but concluded without any new agreement to end the stalemate. Ban Kimoon declared that "there is still work to be done" and that he invited again the two leaders to meet in a similar format on January 2012 (United Nations News Centre 2011). They indeed met again in New York on 23-24 January 2012, but as in all the other previous meetings, this one ended as well without any agreement over the core issues of the conflict (United Nations News Centre 2012). Following these developments, the official negotiations were yet again halted.

The above moments of the peace process are indicative of the perpetuation pattern the Cyprus conflict has embarked on. Despite various attempts at finding a solution, either through direct negotiations between the leaders of the GC and TC communities or through the help of the United Nations, the Cyprus conflict is still unresolved. One retired United Nations official has described the official talks to settle this conflict as being "the most frustrating" ones and compared them with "the gyroscopic stabilizer on a ship in a storm. They go round and round and produce a certain stability, even if they do not produce forward motion." (Urquahart 1987, 259 quoted in Souter 1989, 76). As a result of the failure of the settlements efforts, the conflicting sides remained locked in an adversarial relationship and fixed in terms of fundamental grievances. 


\section{SOCIAL REPRESENTATIONS ABOUT CON FLICT}

\subsection{The representations that the GCs have about the Cyprus conflict}

For the analysis of the social representations that the GCs have about the Cyprus conflict, I selected the following official discourses at the level of the President: President Vassiliou's speech at the 47th session of the United Nations General Assembly (UNGA) in 1992, President Clerides' speech at the 54th session of the UNGA in 1999, President Papadopoulos' inaugural speech at the House of Representatives in 2003, President Papadopoulos' speech during an official visit to Greece in 2003, President Papadopoulos' speech at the 62nd session of the UNGA in 2007, President Christofias' speech at the ceremony of his investiture at the special session of the House of Representatives 2008, President Christofias' speeches at the 66th and 67th sessions of the UNGA in 2011 and 2012. In these official discourses, as compared to others, the Cyprus problem is addressed more broadly and elements pertaining to trauma, representation of the conflict and victimization intersect each other.

GCs represent the conflict in terms of "occupation", "invasion", "refugees", "missing persons", and "foreign aggression". The words that are used most often are "occupation" and "invasion", which are encountered several times within the same discourse, having as an effect the emphasising of the situation in which the GCs are found. This manner of conflict representation is linked with Turkey and the decision to intervene in 1974 in the support of the TCs, which added a third player to the conflict between the two communities. Thus, in their official discourses, the GCs highlight the international aspect that was acquired by the Cyprus conflict through Turkey's intervention from 1974, and the fact that Turkey is in fact the real perpetrator, the enemy in this conflict. From the GCs' perspective, the conflict started in 1974 and it is a matter of invasion and foreign occupation, beside a series of other elements that were caused, such as refugees, missing persons, enclaved persons, loss of territory. The speech of President Papadopoulos during the 62nd session of the UNGA in 2007 is explanative in this sense. According to him "the Cyprus issue, when stripped of niceties of diplomatic terminology, is a question of foreign aggression and continuing occupation of a significant part of a sovereign State, entailing enclaved and missing persons, refugees 
and massive and enduring violations of human rights". In the same speech, Papadopoulos adds that: "the Cyprus problem is not a derivate of bad community relations, but one of outside intervention." The same President Papadopoulos mentions, during an official visit to Greece, that "the crux of the Cyprus problem is the Turkish invasion and occupation." President Christofias clarifies this aspect as well. During a speech held at the 66th session of the UNGA in 2011, he emphasizes that "the essence of the Cyprus problem" is "first and foremost a problem of invasion and occupation, a problem of violation of international law and human rights of Cypriot citizens." The same President Christofias, still at the UNGA, but at the 67th session in 2012, raises again the problem of the 1974 Turkish invasion and of the consequences that it caused on the inhabitants of the island:

\begin{abstract}
"Cyprus still faces the consequences of foreign intervention and of the Turkish invasion and occupation. M ore than one third of the territory of my country is still under military occupation by Turkey... Y et Turkey, after invading Cyprus in 1974, continues to occupy, for 38 years, the northern part of the island, ... to violate human rights and fundamental freedoms of tens of thousands of displaced persons, including the usurpation of their property, the rights of the enclaved and the people who lost their loved ones and continue to search for them."
\end{abstract}

What can thus be noticed is the GCs' constant and continuous preoccupation toward the conflict. The fact that the Cyprus conflict is always inserted into the official discourse of the CGs denotes the importance of the subject within the public agenda and the attention that it is given at this level. Moreover, at the official level, the Cyprus conflict is represented as being an unprecedented tragedy in the history of the country: "In the course of its history, Cyprus has met with attacks, conquests, adventures. The difference with today's barbaric invader is that he came not only to grab, but also to stay on the island..." (President Papadopoulos' speech during an official visit to Greece in 2003). The social representations that the GCs have about the conflict are temporally and contextually framed in 1974, the year that marks Turkey's intervention in Cyprus. For the GCs, this moment and social context represent a collective trauma, which draws painful memories about the assault, the human and material losses they suffered, but also feelings of injustice. This episode is generally described by the GCs as "all hell breaking 
loose" (Volkan 2008, 96), a moment when many GCs became missing persons, were killed, captured or had to run from the violence's path and move in the southern part of the island in order to save their lives. In the selected official discourses of the GCs, the 1974 episode is often remembered in terms of ethnic cleansing. For instance, President Vassiliou, during his speech at the 47th session of the UNGA in 1992, emphasizes "the devastating effects of ethnic cleansing following the Turkish invasion of 1974" and the plight of the GCs who "were evicted from their ancestral homes and properties in order to create ethnically clean areas." During the speech from the 10th session of the UNGA in 1999, President Clerides also mentions "the ethnic cleansing Turkey practiced against Greek Cypriots, which resulted in 180,000 GCs becoming refugees in their own country", "the drama of the relatives of the $1600 \mathrm{GCs}$ missing since the invasion of Cyprus by Turkish forces in 1974" and "the many violations of human rights of the Greek Cypriots."

The above statements are also indicative of the pronounced feeling of being victimised that exists among the GCs. In the official discourses, GCs use frequently the words "to suffer" and "suffering". For instance, in 2011, during the 66th session of the UNGA, President Christofias begins his speech by drawing attention to the sufferings that his country was forced to go through: "The Republic of Cyprus has experienced violence and we still suffer from its consequences. It still suffers from the consequences of the illegal Turkish invasion of 1974 and the ongoing occupation. Thirty-seven later, the Republic of Cyprus [... ] still suffers from the occupation of a large part of its territory by the military forces of Turkey." President Vassiliou talks about the sufferings of the inhabitants of the island as well. According to him, the resolution of the Cyprus conflict will bring "an end to the forcible division of our country and the resulting suffering of so many, particularly of the families of the missing persons" (excerpt from President Vassiliou's speech at the 47th session of the UNGA, 1992). However, President Papadopoulos is the most direct on this issue. During his inaugural speech as president of Cyprus in 2003, he draws attention to the victim status of GCs stating that: "We first and foremost, the members of the Greek-Cypriot community, are anxious to reach a solution of the Cyprus Problem. We most of all care about a quick solution because it is we who as victims of a continuing invasion and occupation, want the immediate cessation of the tragedy of our country...". 
From the above excerpts, one can observe how the GCs attribute the causes of their sufferings to the "other", in this case to Turkey. For the GCs, the victimization appears because of Turkey, and not because of the TCs, given the 1974 traumatic experience. In fact, the TCs appear in the GC official discourses as being citizens of Cyprus, part of the same Cypriot people, and partners. For instance, in their speeches, Presidents Vassiliou and Christofias very often use phrases such as "the people of Cyprus, Turkish Cypriots and Greek Cypriots alike" or "our Turkish Cypriot compatriots" (Vassiliou's speech at the UNGA, 47th session, 1992; Christofias' speech at the ceremony of his investiture 2008) while President Papadopoulos perceives the Turkish Cypriots "as the real partners [...], in a condition of political equality vis-à-vis the state and the law" (speech at the official dinner given in his honour by the President of Greece, 2003). In this context, Turkey becomes the main culprit, but also the only one responsible for the suffering and plight of the Cypriot people.

\subsubsection{Comments}

The analysis of the social representations that the GCs have about the Cyprus conflict sheds light on the following research findings:

- trauma and victimization inform the GCs' social representations about the Cyprus conflict. The GCs' official discourses are built around Turkey's intervention in Cyprus in 1974 which they consider as being the most traumatic experience during the conflict yielding strong feelings of victimization;

- the nucleus of the social representations that the GCs have about the conflict consists of trauma and victimization. Furthermore, GCs' official discourses highlight only the experiences lived by the GCs as a consequence of Turkey's intervention, the emphasis being put only on one own's suffering;

- the constant reference to the 1974 episode and the Turkish intervention suggests a clinging to the past. The need to return to this moment in time and to this social context denotes the non-overcoming of the collective trauma, an unhealed past, the enduring nature of the losses, as well as the need for them to be recognised; 
- the GCs have built a discourse pattern about the conflict centred mainly on the Turkish "invasion" and "occupation" of the territory from Northern Cyprus, on the material and human consequences caused by Turkey's action, as well as on the status of being a victim. For GCs, the Cyprus conflict is a matter of occupation, invasion and aggression, where Turkey is the sole responsible for the grave situation Cyprus is faced with, and where understanding of what the conflict means or is about is done through the perspective of a victim status;

- The centrality of the 1974 episode in the official discourse on the Cyprus problem with focus on the unjust harm and the psychological wounds engendered has the "potential" to enhance polarization and pro-conflict attitudes among GCs, thus also impeding peace-making efforts.

\subsection{The representations that the TCs have about the Cyprus conflict}

For the analysis of the social representations that the TCs have about the Cyprus conflict, I have selected the following official speeches, official letters and interviews of the TC leaders: the speech of Rauf Denktash at the United Nations Security Council in November 1983; the letter dated 22 September 1996 sent by Rauf Denktash to the leader of the GCs, Glajkos Clerides; the interview given by Rauf Denktash to the journalists of a Turkish newspaper on 19 June 1999; the letter dated 31 May 2001 sent by Rauf Denktash to the United Nations; the letter dated 28 November 2008 sent by Mehmet Ali Talat to the United Nations; the letter dated 23 April 2010 sent by the leader of the TCs, Dervish Eroglu, to the United Nations Secretary General. These contain a holistic presentation of the Cyprus conflict from a TC perspective with emphasis on aspects related to trauma and victimization.

The TCs represent the conflict as being an internal problem between two politically equal communities, the GCs and the TCs. They invoke the London and Zurich accords from 1959 - 1960, which created the independent Republic of Cyprus and which established a bicommunal system which gave to the GCs and the TCs political equality. In the letter sent to the leader of the GCs, Glafkos Clerides, on 22 September 1996, Rauf Denktash emphasizes that "the crux of the 
inter-communal dispute is the attempt of the Greek Cypriot side to impose itself on us as "the Government of Cyprus" contrary to the Rule of Law and in complete disregard of the "state of affairs" created by the 1960 Treaties, which gave certain rights to each of the interested parties..." . According to the TCs, since the violent clashes between the two communities from 1963 due to the decision of the then GC leader, Makarios, to amend the constitution and remove certain TC rights, Cyprus has not been led by a single central administration:

"The partnership Republic of Cyprus, which was founded in accordance with international treaties, was in fact destroyed in 1963 by the Greek Cypriot partner's onslaught on the Turkish Cypriot partner, and there has not been a joint central administration in the island ever since. Each side has since ruled itself, while the Greek Cypriot side had continued to claim that it is the "Government of Cyprus". H ence, by late D ecember 1963 there was no longer an entity called "Republic of Cyprus" which reflected the 1960 A greements since one of the partners, namely Turkish Cypriots, were ousted by force of arms from all organs of the State and government" (excerpt from the latter dated 28 November 2008 sent by Mehmet Ali Talat to the United Nations).

The social representations that the TCs have about the conflict with the GCs can be translated into terms of "usurpation", "theft", "discrimination", "subjugation", and "domination". In his speech from November 1983 within the United Nations Security Council, Rauf Denktash, in reference to the situation of the TCs, emphasizes that "one part of a bi-communal government has been robbed by the other part of all its rights and has not given them back...". The same Rauf Denktash, in an interview given to a Turkish newspaper on 19 June 1999, illustrates the issue that Cyprus is being confronted with as being: "in essence, a problem of usurpation of administration. The Cyprus problem is an end product of the Greek Cypriot usurpation of the tile of "Cyprus government" by subjecting us for 11 years [from 1963 to 1974] to conditions that [Y ugoslavian President Slobodan] M ilosovic has done in Kosovo... The Cyprus problem is an end product of Greek Cypriot ambition to dominate us... to render us a minority by subjecting us 0 inhumane practices and by usurping our partnership in the state and sovereignty." 
In the same spirit, Mehmet Ali Talat, in the letter from 28 November 2008 addressed to the UN highlights "the Greek Cypriot usurpation of the Government since 1963". He also clarifies that the Cyprus problem started in 1963, and not in 1974, as the GCs claim, and that it is not a problem of occupation and invasion. Mehmet Ali Talat touches upon a subject that causes factions and deep disagreements between the two communities. Contrary to the GCs, the TCs assert that Turkey's involvement in the Cyprus conflict was legitimate and in accordance with the 1960 Treaty of Guarantee and that the only invasion on the island was that from Greece in 1974 through the junta coup attempt towards Makarios: "It is true that there had been an invasion on the island, but this is certainly not the Turkish intervention of 20 July, which is fully legitimate, as Turkey acted in accordance with her obligations under the 1960 Treaty of Guarantee. Rather, it is the Greek Cypriot usurpation of the Government since 1963 and Greek invasion of 15 July when the junta in A thens staged a coup on the island" (excerpt from the latter dated 28 November 2008 sent by Mehmet Ali Talat to the United Nations).

The TCs claim that Turkey, through its decision to intervene in 1974, saved them from "neutralization", "destruction" and "the conversion" of the partnership obtained through the 1960 accords into a "Greek Cypriot Republic". According to Rauf Denktash, if Turkey had not intervened the "Greek-Cypriots would have butchered us and solved the problem [... ] you would have driven us to the sea [... Even under the unbearable conditions, we kept on defending the Cyprus cause. We ever bowed, never surrendered. We always believed that one day Turkey would come and save us from all the difficulties we were pushed into. Turkey has come and saved us" (excerpt from Rauf Denktash's interview to a Turkish newspaper, 19 June 1999);

"Turkey had a right to rescue us and prevent the conversion of the partnership Republic into a Greek Cypriot Republic. But if Turkey moved in order to fulfil her obligation, then by the time Turkey arrived we would be "neutralized" in Cyprus [... ] M akarios wanted to abrogate the agreements so that Turkey would not have the right to intervene while he destroys the Turkish Cypriot community [...] The system prevented you from destroying us and from converting the island into a Greek Republic" (excerpt from Rauf Denktash' letter dated 22 September 1996 sent to the GC leader, Glafkos Clerides); 
"Turkey, as a guarantor Power, has protected and continues to protect the most basic human rights on the island and, thanks to Turkey, there has been no bloodshed in Cyprus for the past 27 years" (excerpt from Rauf Denktash's letter dated 31 May 2001 and sent to the United Nations). The same importance of the guarantee treaty from 1960 is also highlighted by Dervish Eroglu in the letter sent to the United Nations Secretary General, Ban Ki-moon, on 23 April 2010: "M oreover, the continuation of the 1960 system of guarantees [... ] is vital for the Turkish Cypriot side."

The temporal and contextual framing of the social representations TCs have about the conflict is marked by the period of time between 1963 and 1974, when they had to live in enclaves in very harsh conditions. For the TCs, this moment and social context represent a collective trauma that generates painful memories of the suffering that they were submitted to and feelings of victimization and humiliation. From the above excerpts, it can be noticed the presence of words such as "inhumane", "unbearable" or "difficult" that the TCs use in describing the 1963 - 1974 period: "inhumane practices", "unbearable conditions", "all the difficulties we were pushed into". Other types of expressions used by the TCs in describing the same period are: "the indignities and harassment of the 1963-1974 period", "atrocities", "massacres", "tragedies", "the horrendous nature of the events between 1963-1974", "ill treatment" (excerpt from Rauf Denktash' letter dated 22 September 1996 sent to the GC leader, Glafkos Clerides); "unjust and inhuman isolations", "inhuman restrictions", "veritable siege" (excerpt from Mehmet Ali Talat' letter dated 28 November 2008 and sent to the United Nations). The eleven years that the TCs refer to in the official discourses as well as the types of expressions used in describing these years, suggest suffering, pain and distress. During this period, TCs were crowded in enclaves, which covered only $3 \%$ of the island, and surrounded by three lines of soldiers belonging to the United Nations, TC and GC communities (Bryant 2012, 7). According to Rauf Denktash, the GCs "forced" TCs "out of 103 villages and locked us in 3\% of the island" (excerpt from the interview Rauf Denktash gave to a Turkish newspaper, 19 June 1999). Within the enclaves, TCs endured harsh conditions, "inhuman" as the TC leaders constantly repeat in their discourses, including limited housing, food and other material shortages. The TC people lived in tents, caves, and warehouses while 
being practically imprisoned in the enclaves and, until 1968, they lived in isolation without any access to their homes, lands or the possibility to visit other enclaves (Volkan 2008, 96-97). They have been subjected to "overwhelming stress and change" and became "victims of the massive psychic trauma of expulsion from their homes, the loss of many dear to them, and constant fear" (Volkan 1979, 81).

The selected official discourses of TC leaders speak about a community which suffered many years of difficulties, annihilation anxiety and isolation, and which felt oppressed at the hand of GCs. They refer to the TCs humiliation and dehumanization inflicted by GCs, and to the many human rights deprivations they suffered during the years living in the enclaves (Volkan 2008, 97-98). The feeling of being victimized among the TCs is entirely attributed to the GCs due to the traumatic experiences lived between 1963 - 1974. The GCs appear as guilty of the sufferings endured by the TCs, while the latter consider themselves as the victims of the GCs. This victimization feeling was formed in the course of a long period of conflict, and as a result of the loss and damage suffered by TCs. In the official discourses, the TCs' references to the 1963 - 1974 period contain also descriptive elements that come in the support of their claims regarding the sufferings as well as the violence they were submitted to, and indicate the viciousness of GCs acts towards them. For instance, in the letter dated 22 September 1996 and addressed to the GC leader, Glafkos Clerides, Rauf Denktash inserts what he names "cleansing operations" "mercilessly" directed by the GCs against the TCs, and describes in detail the manner in which the GCs attacked and killed TCs people, no matter the age or sex:

"Even sixteen-day old babies, 1, 2, 3, year olds were not spared. 80-90 years old people were mercilessly gunned down [... ] elementary school-children lined up and shot [...] I enclose for your eyes the pictures of mass graves in Ayios Vasilios where in December 1963 the Turkish Cypriot civilians (women and children, old men and women) were taken from their homes, lined up and shot. The number of Turkish Cypriots killed and wounded and the missing during 1963-1974 runs into several thousands." 


\subsubsection{Comments}

The analysis of the social representations that the TCs have about the Cyprus conflict sheds light on the following research findings:

- trauma and victimization influence the forming of the TCs' social representations about the Cyprus conflict. The official discourses of the TCs are built around the collective trauma caused by the "inhumane practices", "unbearable conditions" and the "veritable siege" that took place between 1963 1974 and the victimization generated at the collective level by this traumatic period;

- the trauma and victimization at the collective level caused by the sufferings, torment and injustices that happened between 1963 - 1974 constitute the central part of the social representations that the TCs have about the conflict. This period of eleven years represents a reference point which is profound (because it encapsulates all the endured abuses and injustices) and acute (because the suffering is still ongoing);

- the construction of the social representations that the TCs have about the conflict by resorting to the traumatic experiences and sufferings associated with the 1963 - 1974 period suggests a strong connection to the past, the persistence of the traumatic memories and the need for the recognition of the endured sufferings;

- the TCs' official discourses about the conflict follow a pattern mainly focused on the plight of the TCs who seen themselves as victims of GCs perceived to be the main responsible for the sufferings endured along the conflict, especially between 1963-1974, and for the situation they are encountered in the present;

- the repetitive references of the 1963-1974 period that invokes in the TCs feelings of humiliation and victimization by GCs, the blame and the recall of what the enemy has committed in the past accentuate the divide, promotes conflict and blocks the opening towards co-existence or future collaboration with GCs. 


\section{CONCLUSIONS}

The Cyprus conflict is an intractable conflict that has been on the agenda of the international community for more than five decades, has gone through sporadic episodes of violence and had resisted to the multiple efforts of resolve laid down by third parties. The research approach of this paper attained its objectives, namely it highlighted the interdependent relationship between social representations, trauma, and victimization in the Cyprus conflict as well as the connection between them and the perpetuation of this conflict.

Firstly, the two communities have developed different social representations about the conflict they are involved in. For the GCs, the conflict is a matter of foreign occupation, aggression and invasion linked to Turkey's decision to militarily intervene on the territory of Cyprus in 1974. For the TCs, the conflict is an inter-communal strife between two politically equal communities, which began in 1963 with the decision of the then GC leader, Makarios, to amend the constitution and try to outpower the TC community. Thus, one can notice the existence of certain fundamental differences in interpretation of the same historical events, leading to a collision between the two parties' official discourses.

Secondly, the leaders of the two communities emphasize two different moments of time and social contexts as being the most traumatic experiences that they went through during the conflict. The GCs focus on the year of 1974, the month of July, which marks Turkey's military intervention in Cyprus, while the TCs focus on the 1963 - 1974 period, which marks some long-lasting eleven years of living in enclaves in isolation, deprivation and harsh conditions. These represent turning points for the trajectories of the two communities and form collective traumas, engendering strong feelings of victimization. Furthermore, one can notice two opposing official discourses about the conflict where each party choose to remember and emphasize only its own suffering, with little regard towards the other's own pain, thus constructing what Maria Hadjipavlou (2009, 26) calls on her writings an "ecliptic reality".

Thirdly, collective trauma and victimization lie central to the way in which each party represents the conflict. The prioritization of these two aspects in the 
emotional official discourses of GCs and TCs about the Cyprus conflict suggests the impossibility to detach from these traumatic experiences, the strong orientation toward the unhealed past, the importance the parties attach to the past and its domination over the present as well as the need for the pain to be recognized. Also, the collective past traumas seem to obscure the parties' ability to acknowledge the grievances of the "other". The analysis of the official discourses indicates a lack of recognition of each other's collective traumas from both parties. They remain bound to the injustices inflicted by the "other" concentrate only on their own traumas and sufferings, do not make any references to the traumatic events experienced by the adversary, thus contributing to the deepening of divisions between them.

Fourthly, the different social representations that the GCs and the TCs have about the conflict are influenced by the collective past traumas and by victimization. The latter constitute a "central nucleus" (Abric 1994a) of the two parties' social representations of the conflict that petrifies in the face of a continued lack of resolve. Moreover, the social representations that are thus formed bring back into discussion the traumatic past experiences and the sense of victimization. This is why each replay of the traumatic events in the official discourses of the two parties (the Turkish invasion from July of 1974 for the GCs, and respectively the 1963 - 1974 period and the living in enclaves, in isolation, for the TCs) remakes the original sense of the trauma topical and reinforces the collective feeling of victimization of the two communities. Hence, what results is an interdependent relationship between social representations, trauma and victimization as well as the manner in which they mutually determine each other.

Fifthly, the role that trauma and victimization hold in forming the social representations of the GCs and TCs about the conflict, as well as the function had by the social representations that are thus formed, namely of remaking and reinforcing the trauma and the feeling of victimization topical, determine the perpetuation of the Cyprus conflict. In the dynamic of this conflict, the social representations, the trauma and the victimization are important components, with a content that is rich value-wise and information-wise. They support the divide between the GCs and the TCs, cultivate a culture of separation, deepen 
the "us" and "them" dichotomy, thus also hindering the settlement's efforts. In other words, they are acting as blockages to peace. As resulted from the analysis of the GCs and TCs' official discourses, these are competitive, based on an adversarial model, implying the conflict is not seen as a shared problem to settle. They do not seem to promote a pro-solution culture, rather fortifies pro-conflict attitudes, polarization, animosity by always pointing the other's guilt and using the victimhood argument.

The research findings illustrate a mutually reinforcing relationship between social representations, trauma and victimization which negatively influence the settlement of the Cyprus conflict. Furthermore, they highlight the importance that these psychosocial factors have in the dynamics of the Cyprus conflict and contribute to a better understanding of its essence. In turn, such an understanding could also offer a path towards the further development of a more efficient formal peace process.

\section{REFERENCES}

- Abric, Jean-Claude. 1994a. "Les représentations sociales: aspects théoriques." In Pratiques sociales et representations, edited by Jeav-Claude Abric, 11-35. Paris: Presses Universitaires de France.

- $\quad$ Anastasiou, Maria.2007. "The Institutionalization of Protracted Ethnic Conflicts: A Discourse Analysis of "The Cyprus Problem"." PhD diss., University of South Carolina.

- $\quad$ Azar, Edward E. 1990. The M anagement of Protracted Social Conflict: Theory and Cases. Aldershot, Hampshire, England: Dartmouth.

- $\quad$ Bar-Tal, Daniel, Lily Chernyak-Hai, Noa Schori and Ayelet Gundar. 2009. "A sense of self-perceived collective victimhood in intractable conflicts." International Review of the Red Cross, 91 (874): 229-258.

- Bar-Tal, Daniel. 2007. "Sociopsychological Foundations of Intractable Conflicts." A merican Behavioral Scientist, 50 (11): 1430-1453.

- $\quad$ Bar-Tal, Daniel. 2013. Intractable Conflicts: Socio-Psychological Foundations and D ynamics. Cambridge, UK: Cambridge University Press.

- Bar-Tal, Daniel. 2014. "Collective memory as social representations." Papers on Social Representations, 23: 5.1-5.26. 
- Bar-Tal, Daniel, Eran Halperin, Ruthie Pliskin. 2014. "Why Is It So Difficult To Resolve Intractable Conflicts? A Sociopsychological Explanation." In $\mathrm{H}$ andbook of International Negotiations: Interpersonal, Intercultural, and Diplomatic Perspectives edited by Mauro Galluccio, Switzerland: Springer.

- $\quad$ Brewer, Marilynn. 2011. "Identity and Conflict." In Intergroup Conflicts and Their Resolution. A Social Psychological Perspective, edited by Daniel Bar-Tal, 125-143. New York: Psychology Press Taylor \& Francis Group.

- Bryant, Rebecca. 2012. Displacement in Cyprus. Consequences of Civil and Military Strife. Report 2. Life Stories: Turkish Cypriot Community, PRIO Cyprus Centre. http://www.prio-cyprusdisplacement.net/images/users/1/Report\%202-\%20R.BRYANT\%20ENGWEB.pdf

- $\quad$ Burton, John. 1987. Resolving Deep-Rooted Conflict: A H andbook. Lanham MD: University Press of America.

- Coleman, Peter. 2006. "Intractable Conflict." In The H andbook of Conflict Resolution. Theory and Practice, edited by Morton Deutsch, Peter Coleman and Eric Marcus, 533-559. San Francisco: Jossey-Bass.

- Deutsch, Morton. 1985. Distributive Justice: A Social Psychological Perspective. New Haven: Yale University Press.

- $\quad$ Erikson, Kai. 1995. "Notes on Trauma and Community." In Trauma: Explorations in Memory, edited by Cathy Caruth, 183-200. Baltimore: John Hopkins University Press.

- Fisher, Ronald J. 2001. "Cyprus: The Failure of Mediation and the Escalation of an Identity-Based Conflict to an Adversarial Impasse." Journal of Peace Research, 38 (3): 307-326.

- $\quad$ Fisher, Ronald J., and Herbert C. Kelman. 2011. "Perceptions in Conflict." In Intergroup Conflicts and Their Resolution. A Social Psychological Perspective, edited by Daniel Bar-Tal, 61-81. New York: Taylor and Francis Group.

- Friedman, Matthew J. 2016. "PTSD History and Overview". PTSD: National Center for PTSD, U.S. Department of Veterans Affairs. https://www.ptsd.va.gov/professional/ptsd-overview/ptsd-overview.asp

- Goertz, Garry and Paul F. Diehl.1993. "Enduring rivalries: Theoretical Constructs and Empirical Patterns." International Studies Quarterly, 37 (2): 147171.

- Gross Stein, Janet. 1996. "Image, Identity and Conflict Resolution." In $\mathrm{M}$ anaging Global Chaos, edited by Chester Crocker, Fen Hampson and Pamela Aall, 93-111. Washington, D.C.: United States Institute of Peace Press. 
- Hadjipavlou, Maria. 2007. "The Cyprus Conflict: Root Causes and Implications for Peacebuilding." J ournal of P eace R esearch, 44 (3): 349-365.

- Hadjipavlou, Maria. 2009. "Reconciliation in Protracted Conflict. The Cypriot experience from the non-governing elite perspective". Paper presented at the International Society of Political Psychology 32 ${ }^{\text {nd }}$ Annual Meeting, Trinity College Dublin, July 14-17.

- Hadjipavlou, Maria. 2017. "The "Crossings" along the Divide: the Cypriot Experience." In The Walls between Conflict and Peace, edited by Alberto Gasparini, 197-216. Leiden: Brill.

- Hadjipavlou-Trigeorgis and Leon Trigeorgis. 1993. "An Evolutionary Approach to Conflict Resolution." The Journal of Conflict Resolution, 37 (2): 340360.

- $\quad$ Hunter, Andrea K., and Abigail J. Stewart. 2015. “Past as Prologue: How History Becomes Psychologically Present." Journal of Social Issues, 71 (2): 219-228.

- Kelman, Herbert. 2007. "Social-Psychological Dimensions of International Conflict." In Peacemaking in International Conflict. M ethods and Techniques, edited by I. William Zartman, 61-107. Washington, D.C.: United States Institute of Peace.

- Kriesberg, Louis. 2005. "Nature, Dynamics, and Phases of Intractability." In Grasping the N ettle. A nalyzing Cases of Intractable Conflict, edited by Chester A. Crocker, Fen Osler Hampson, and Pamela Aall, 65-97. Washington, D.C.: United States Institute of Peace Press.

- $\quad$ Küçükkoşum, SEVİL. 2010. “Turkish Cypriot leader ready for tripartite New York meeting." Hürriyet Daily News, October 22, 2010. http:/ / www.hurriyetdailynews.com/turkish-cypriot-leader-ready-for-tripartitenew-york-meeting.aspx?pageID $=438 \& n=$ turkish-cypriot-leader-ready-for-unchief8217s-call-tripartite-meeting-2010-10-22

- Mack, John, 1990. "The Enemy System." In The Psychodynamics of International Relationships. Vol. I: Concepts and Theories, edited by Vamik D. Volkan, Julius A. Demetrios and Joseph V. Montville, 83-95, Lexington, MA: Lexington Books.

- $\quad$ Michael, Michális, 2009. Resolving the Cyprus Conflict. N egotiating History. New York: Palgrave Macmillan.

- $\quad$ Mohatt, Nathaniel V., Azure B. Thompson, Nghi D. Thai, and Jacob K. Tebes. 2014. "Historical trauma as public narrative: A conceptual review of how history impacts present-day health." Social Science \& M edicine, 106: 128-136. http:/ / doi.org/10.1016/j.socscimed.2014.01.043 
- Morelli, Vincent L. 2015. Cyprus: Reunification Proving Elusive. Congressional Research Service Report:1-37. https:/ / fas.org/sgp/crs/row/R41136.pdf on 15/03/2017

- Morris, Harvey. 2010. "Parties in Cyprus dispute agree more UN talks." Financial Times, November 19, 2010. https://www.ft.com/content/94ddc47af342-11df-a4fa-00144feab49a

- Noor, Masi Nurit Shnabel, Samer Halabi, Arie Nadler. 2012. "When Suffering Begets Suffering." Personality and Social Psychology Review, 16 (4): 351 374.

- $\quad$ Security Council Report. 2008. "Cyprus: New Hope After 45 Years On The Security Council Agenda", no. 3. September 4, 2008. http:/ / www.securitycouncilreport.org/atf/cf/\%7B65BFCF9B-6D27-4E9C-8CD3CF6E4FF96FF9\%7D/Research\%20Report\%20Cyprus\%204\%20Sep\%2008.pdf

- $\quad$ Souter, David. 1989. "The Cyprus Conundrum: The Challenge of the Intercommunal Talks." Third W orld Q uarterly, 11 (2): 76-91.

- Staub, Ervin. And Daniel Bar-Tal. 2003. "Genocide, mass killing and intractable conflict: Roots, evolution, prevention and reconciliation." In Oxford $\mathrm{H}$ andbook of Political Psychology, edited by David O. Sears, Leonie Huddy, Robert Jervis, 710-751. New York: Oxford University Press.

- Theophanous, Andreas and Odysseas Christou. 2014. "The Cyprus Question and the Role of the UN: An Overall Assessment." The Journal of M odern H ellenism, 30: 73-89. http://journals.sfu.ca/jmh/index.php/jmh/article/view/7

- $\quad$ Tint, Barbara. 2010. "History, Memory, and Intractable Conflict." Conflict Resolution Quarterly, 27 (3):239-255.

- United Nations Secretary-General. 2004. The Comprehensive Settlement of the Cyprus Problem, March 2004. http:/ / www.hri.org/docs/annan/Annan_Plan_April2004.pdf

- United Nations Security Council. 2004. Report of the Secretary-General on his mission of good offices in Cyprus, May 28, 2004. http:/ / www.un.org/en/ga/search/view_doc.asp?symbol=S/2004/437

- United Nations Security Council. 1964. Resolution 186, The Cyprus Question, March

4 , 1964. http:/ / www.un.org/en/ga/search/view_doc.asp?symbol=S/RES/186(1964) - United News Centre. 2012. Cyprus: Ban calls for decisive steps towards final settlement after intensive talks, 25 January 2012. http:/ / www.un.org/apps/news/story.asp?NewsID=41035\#.WRtEp8b-vIX 
- United News Centre. 2011. Cyprus: leaders agree to intensify reunification talks after meeting with Ban, 26 January 2011. http://www.un.org/apps/news/story.asp?NewsID=37386\#.WRtDIMb-vIV

- United News Centre. 2011. Deal between Greek Cypriot and Turkish Cypriot leaders is attainable - Ban, 1 November 2011. http://www.un.org/apps/news/story.asp?NewsID=40271\#.WRtEc8b-vIX

- $\quad$ United News Centre. 2017. Greek Cypriot and Turkish Cypriot leaders agree to greater UN role in talks - Ban, 7 July 2011. http://www.un.org/apps/news/story.asp?NewsID=38967\#.WRtEAMb-vIX

- Volkan, Vamik D. 1998. Bloodlines: From Ethnic Pride to Ethnic Terrorism. Boulder, CO: Westview Press.

- Volkan, Vamik D. 2008. “Trauma, Identity and Search for a Solution in Cyprus." Insight Turkey, 10 (4): 95-110.

- Volkan, Vamik D. 1979. Cyprus - War and Adaptation. A Psychoanalitic History of Two Ethnic Groups in Conflict. Charlottesville: University Press of Virginia.

- Wertsch, James V., and Henry L. Roediger, H. III. 2008. "Collective memory: Conceptual foundations and theoretical approaches." M emory, 16 (3): 318-326.

- $\quad$ Sources for the selected speeches of GCs leaders:

- $\quad$ President Vassiliou's speech at the 47th session of the UNGA, 1992. Available at http://www.un.org/ga/search/view_doc.asp?symbol=A/47/PV.7

- $\quad$ President Clerides' speech at the 54th session of the UNGA, 1999. Available

http://www.un.org/ga/search/view_doc.asp?symbol=A/54/PV.10

- President Papadopoulos' inaugural speech at the House of Representatives, $2003 . \quad$ Available at http://www.piopressreleases.com.cy/easyconsole.cfm/page/search

- $\quad$ President Papadopoulos' speech during an official visit to Greece, 2003. Available http://www.piopressreleases.com.cy/easyconsole.cfm/page/search

- $\quad$ President Papadopoulos' speech at the 62nd session of the UNGA, 2007. Available at http://www.un.org/ga/search/view_doc.asp?symbol=A/62/PV.7

- $\quad$ President Christofias' speech at the ceremony of his investiture at the special session of the House of Representatives, 2008. Available at http://www.piopressreleases.com.cy/easyconsole.cfm/page/search 
- $\quad$ President Christofias' speech at the 66th session of the UNGA, 2011. Available http://www.un.org/ga/search/view_doc.asp?symbol=A/66/PV.15

- $\quad$ President Christofias' speech at the 67th session of the UNGA, 2012. Available http://www.un.org/ga/search/view_doc.asp?symbol=A/67/PV.6

- $\quad$ Sources for the selected speeches, letters and interviews of TCs leaders: - Speech of Rauf Denktash at the United Nations Security Council, November 1983. Available at https:/ / www.youtube.com/watch?v=Couo4LeSP88

- $\quad$ Letter dated 22 September 1996 sent by Rauf Denktash to the leader of the GCs, Glajkos Clerides. Available at http://www.mfa.gov.tr/letter-sent-bytrnc-president-rauf-denktas-to-the-greek-cypriot-leader-glafkos-clerides_-22september-1996.en.mfa

- Interview given by Rauf Denktash to the journalists of a Turkish newspaper on 19 June 1999. Available at http:/ / www.hurriyetdailynews.com/exclusive-interview-with-president-raufdenktas-of-the-turkish-republic-of-northerncyprus.aspx?pageID $=438 \& n=$ exclusive-interview - with-president-rauf-denktasof-the-turkish-republic-of-northern-cyprus-1999-06-19

- $\quad$ Letter dated 31 May 2001 sent by Rauf Denktash to the United Nations. Available at http:/ / www.un.org/documents/ga/docs/55/a55986.pdf

- $\quad$ Letter dated 28 November 2008 sent by Mehmet Ali Talat to the United Nations. Available at http://repository.un.org/bitstream/handle/11176/11909/A_63_578\%3BS_2008 _749-EN.pdf?sequence $=23$

- $\quad$ Letter dated 23 April 2010 sent by Dervish Eroglu to the United Nations. Available at http://kiatipis.org/cyprus_problem_eng/postings/2010-0423_D.Eroglu.htm 


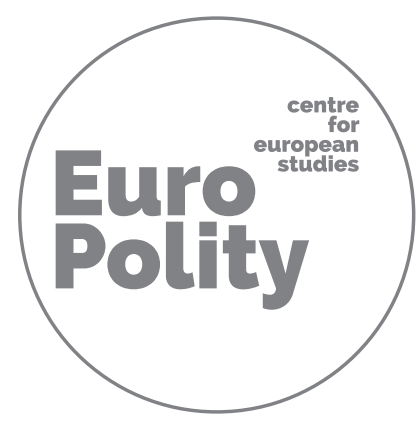




\title{
THE CROSS-BORDER COOPERATION BETWEEN ROMANIA AND UKRAINE IN THE CONTEXT OF THE EASTERN PARTNERSHIP (EPP) AND ASSOCIATION AGREEMENTS
}

(AA) ${ }^{1}$

\author{
Mircea Brie \\ University of Oradea \\ Oradea/Romania \\ briedri@hotmail.com
}

\begin{abstract}
This paper is an analysis of the European Union's policies in the Neighborhood area at its Eastern border, with a particular focus on the special neighborhood relations developed with Ukraine. The premises of this paper are built around the idea that Romania, as an EU member state, moving within the European policies for cross-border cooperation and by using the European instruments, develops a legislative and institutional framework meant to deepen this cooperation at its border with Ukraine. The cross-border cooperation between
\end{abstract}

${ }^{1}$ This current paper is a revised and added edition of one of my contributions to the volume Iordan Gheorghe Bărbulescu (coord.), Mircea Brie, Nicolae Toderaş, Cooperarea transfrontalieră între România şi Ucraina, respectiv între România şi Republica Moldova. Oportunităţi şi provocări între 2014-2020, Tritonic, Bucureşti, 2016, 232 p. The study "Cooperarea transfrontalieră între România şi Ucraina, respectiv între România şi Republica Moldova. Oportunităţi şi provocări în perioada 2014-2020”, is part of the series "Studii de Strategie şi Politici SPOS 2015”, issued under the European Institute in Romania (IER).

The present paper is published under the framework of Jean Monnet Centre of Excelence „In and Out: Understanding the European Union Beyond Its Borders", nr. 565330-EPP-1-2015-1-RO-EPPJMO-CoE 
Romania and Ukraine has been marked by the general framework of bilateral relations, but also by the geopolitical context of the two states. Immediately after the fall of communism and the collapse of the USSR, there were difficulties in cooperation between the young Ukrainian state and the Romanian one. The relationship with Ukraine went through a period of mutual mistrust, so that the two countries have started a process of relaxation of their relations, and as a consequence, the EU has been contributing to it, as well. This cooperation has been marked by legislative and institutional changes stemming from a process of normalization and stimulation of relations with Ukraine, due inter alia to EuroAtlantic integration. The ENP also contributes to this cross-border mechanism through financial instruments, as well as legislative harmonization on both sides of the EU's external borders. The European Neighborhood and Partnership Instrument, seen as an incentive in the process of developing relations with the EU's neighbors, was thus able to create bridges at both political, socio-economic, cultural and cross-border level.

\section{Keywords}

Cross-border cooperation, Eastern Partnership, European Union, Neighborhood, Ukraine

\section{INTRODUCTION}

This paper is an analysis of the European Union's policies in the Neighborhood area at its Eastern border, with a particular focus on the special neighborhood relations developed with Ukraine. The analysis has as a starting point other research in areas such as cross-border cooperation, border studies, and neighborhood relations at the eastern border of the EU. Our own research carried out done within the study "Cooperarea transfrontalieră între România şi Ucraina, respectiv între România şi Republica Moldova. Oportunități şi provocări în perioada 2014-2020", issued under the European Institute in Romania together with Professor Iordan Gheorghe Bărbulescu and Professor Nicolae Toderaş, provide the starting point for the development and furthering this subject. 
The premises of this paper are built around the idea that Romania, as an EU member state, moving within the European policies for cross-border cooperation and by using the European instruments, develops a legislative and institutional framework meant to deepen this cooperation at its border with Ukraine. In this sense, we intend to contextualize the deepening and the necessity to change the mechanisms of the European Neighborhood Policy on the background of the European enlargement to the east of the continent, but also of the new geopolitical realities introduced by Russia's manifestations of force in the European proximity space. EU interests meet with those of Russia, often divergent. Russia's rhetoric of hostility to the West, considered expansive, has led the former Soviet states in Eastern Europe to reposition themselves, to renegotiate their relations with the EU. The European Union also faces the necessity in this context to reform its policies, including privileged relations with some partners such as Ukraine. The European enlargement to the East acquires other valences, more particular in relation to the new realities, including the internal policy of these states. The reformation and rethinking of the internal mechanisms of the European Neighborhood Policy is analyzed in analogy with the results of this policy during the various stages of the EU's relations with the two countries. The position of this state in the Eastern Partnership and then the Association Agreements were chosen as benchmarks in the analysis of the Romanian-Ukrainian cross-border cooperation. The analysis of EU official documents reveals a clear concern for it to reform its neighborhood policies, in particular those relating to the countries of Eastern Europe (Brie 2017, 123).

Another defining element in our analysis is that this cross-border cooperation must be carried out in the limit and in the spirit given by the status of the border between Romania and Ukraine as an external border of the EU. Last but not least, the conflicts in eastern Ukraine and the new dynamics of EU - Ukraine relations have been able to have a direct impact on this cross - border cooperation. 


\section{CROSS-BORDER COOPERATION AT THE EASTERN BORDER OF THE EU - A BRIEF ANALYSIS OF CONCEPTS AND CONTEXT ${ }^{1}$}

Cross-border cooperation can be defined in relation to the direct collaboration between neighboring regions found along a border, regardless of the levels at which this relationship is achieved. This cooperation can take place in all areas, among all national, regional and local authorities, involving all actors. The efficiency, reliability, authenticity and legitimacy of European construction, European integration are also related to the success of cross-border cooperation. "The basic principle of cross-border cooperation is the creation in the border areas of contractual spaces in order to find common solutions to similar problems, the state entities not defining, in relation to their peripheral collectivities, the peculiarity and specificity of the neighboring problems faced by them." (Ricq 2000, 10). The cross-border cooperation proves to be "a kind of mutual cooperation between two neighboring border regions" (Cooperare transfrontalieră 2017). This involves states, regions, administrative units from different levels and/or social groups, etc., covering all areas of everyday life and participating in the development of common programs, priorities and actions (Cooperare transfrontalieră 2017). Cross-border cooperation is favored by cultural, ethno-linguistic, historical (see the case of the Habsburg legacy in Central Europe) or the presence of national minorities. The Romanian Community of Ukraine or the Ukrainian communities in Romania are favorable elements in the process of cross-border co-operation.

1 For more details see Iordan Gheorghe Bărbulescu (coord.), Mircea Brie, Nicolae Toderaş, op. cit., p. 53-61. M ircea Brie, The European Neighborhood Policy, Mass-media and Cross-border Cooperation, in Analele Universităţii din Oradea, Seria Relaţii Internaţionale şi Studii Europene, 2009, p. 81-86; Mircea Brie, Europe from Exclusive Borders to Inclusive Frontiers: Case Study Romanian - Ukrainian Frontier, in loan Horga, Istvan Suli-Zakar (coord.), Cross-Border Partnersip with Spacial Regard to the HungarianRomanian-Ukrainian Tripartite Border, Oradea-Debrecen, 2010, p. 23-36. 
Over time, co-operation at the European border has experienced a nuancing process from the perspective of European policies. Thus, at the EU's internal borders we have the Cohesion Policy and, at the external borders, the European Neighborhood Policy (For more details, see Brie 2010, 265-280; Brie and Horga 2009, 302-318), the former being designed to reduce the gaps between the more developed and the least developed regions and Member States (For more details, see Bărbulescu 2015, 305-310), while the other brings a new approach to the relations between the European Union and its neighbors, superior to the traditional one based on simple co-operation (Europa in direct. Cooperare transfrontalieră 2017). Whether we are looking at the EU's internal level or looking at the case of its external borders, cross-border cooperation has proved to be a promoter of integration, at least at regional level. Over time, regions have often proved to be "cross-border inter-regional micro-integration models" (Ricq 2000, 11), which also deserves attention in the future on shaping policies related to the European construction process. From this point of view, territorial, cross-border or other form of co-operation is a means 'that the human being uses socially, in order to achieve their goals of increasing the quality of life' (Strategia de dezvoltare a județului Satu M are până în 2020. COM PAS 20 - Concepții și Orientare M odernă, Planificare A rmonioasă și Strategică până în 2020, Chapter 8).

The effectiveness of the cross-border cooperation depends on the co-ordination of all actors involved in this process, but also on cooperation at all levels, coupled with the existence of an appropriate legal framework. Malfunction at one of the levels may cause it to fail. Therefore, cross-border cooperation is no longer strictly the status of states, as international actors. An important role in this process is played by the local and regional administrative structures in the border areas, the development associations created by them, as well as the transnational corporations interested in promoting an economic and political environment favorable to business development (Săraru 2011, 88). In order to be successful, border areas need to cooperate with cross-border peer partners and respect the interests of each stakeholder. The European Union encourages and stimulates the development of partnerships in cross-border cooperation. The EU's interest is not only to harmoniously develop the regions on either side of the border or the security interest in the development of a neighboring 
cooperative and stable region, but also to strengthen the European spirit and identity among its citizens beyond their national-ethnic identities (Brie and Blaga 2015). 'Financial instruments and non-financial efforts (e.g. promotion of standards for enhancing competitiveness, methodological approaches, legal framework regulatory adjustment etc.) of European partners in border areas are consistent and projected for a long time' (Roșcovan, Bulat, Puntea and Miron 2010, 101). Cross-border cooperation, both at interstate, regional and local level, has been the focus of the European institutions throughout the European construction process. To make this collaboration more effective and to drive the many existing initiatives together, the creation of a normative framework has been attempted, including models of partnership and association agreements ${ }^{1}$. Under the influence of the European Neighborhood Policy, the European Union's external border concept tends to take on new forms of expression. On the one hand, we find flexibility in contacts between the two sides of the border. Such a trend is amplified through cross-border cooperation mechanisms, through Euroregions, as well as European instruments successfully implemented at the external border. On the other hand, the actions of the European Union that try to implement regional cohesion policies at its current borders, according to some analysts, prove that the Union strengthens its current external borders, taking into account, at least for the moment, the variant of slowing the process extending eastwards, without actually closing the gates ${ }^{2}$.

${ }^{1}$ See Convenția-cadru europeană privind cooperarea transfrontalieră a colectivităților sau autorităților teritoriale, Madrid, 21 mai 1980, http://conventions.coe.int/Treaty/EN/Treaties/PDF/Romanian/106-Romanian.pdf, accessed in 06.10.2017.

2 Referring to the "orange revolution" in Ukraine, the European Commissioner for External Relations and European Neighborhood Policy Benita Ferrero-Waldner said on December 1, 2004 that „la question de l'Ukraine dans l'UE n'est pas à l'ordre du jour. Mais il est clair que nous ne fermons aucune porte". See Régis Matuszewicz, Vers la fin de l'Élargissement?, in Laurent Beurdeley, Renaud de La Brosse, Fabienne Maron (coord.), L'Union Européenne et ses espaces de proximité. Entre stratégie inclusive et parteneriats removes: quell avenir pour le nouveau voisinage de I'Union?, Bruxelles, Bruylant, 2007, p. 109. 
Regarded in the regional context, the ENP appears against the backdrop of EU enlargement to the east corroborated with the change of Russia's strategy vis-àvis Eastern Europe. The region was included in the ENP and later in the PaE, and Russia perceives the area as part of its close neighborhood, a region separating it from the EU and NATO and part of what Russia called the 'Russo-Soviet identity' (Perepelytsia 2010, 105) (especially Ukraine, thus the aggressive attitude that Moscow adopted ante and post Vilnius). Under this paradigm the Ukrainians were considered to be 'Russians who speak one of the dialects of the Russian language' (Perepelytsia 2010, 105). Thus Russia has perceived and still perceives any approximation of the Republic of Moldova and Ukraine to the EU / NATO as a loss of its own influence in the area. On the other hand, Eastern Europe was seen by European leaders as a geopolitically problematic area, being located between two regional powers, but also because of the internal problems these countries faced and which affected the whole region, such as organized crime, drug trafficking, etc. (Gruszczak 2010). In consequence, the relationship developed by the EU with the Republic of Moldova and / or Ukraine was perceived in negative terms by Russia's competition, which may explain future developments in this area ${ }^{1}$.

Considering all these aspects, the cross-border cooperation was no longer a desideratum, but a necessity by which to raise the level of security from the future borders of the EU and to transform the relationship between the EU and the states of the region from a zero-sum game of a win-win type. We see thus, through the implementation of the ENP, a change of perception on the external border. In such a situation, regions and people outside Community structures can benefit from programs and policy instruments that bring them closer to EU citizens. The European Neighborhood Policy makes a significant contribution, through its territorial cooperation programs at the external border, to the

${ }^{1}$ About the East-West relation and the Russian role in this equation see a recent study by Ana Maria Costea, East versus West, When Politics collide with economics, Tritonic, 2015 
development of a more homogeneous system (Hubeny-Berlsky 2007, 317) and to 'integrated regional development'(Hubeny-Berlsky 2007, 320).

Border space involves neighborhood relations. The doctrine defines good neighborliness as a 'state of fact', 'inevitability' (the neighbors are given by history and geography), there have been peoples and states since they have generated two reactions at the frontiers: maintaining the state of security by solving conflicts and the maintenance of cooperation relations between neighboring (Apud Brie 2009, 83). Good neighborliness is closely related to the concept of 'border', even though, over time, the role of the border has changed from the barrier, becoming a little bit of a meeting point between different realities that reveal the possibility of complementarity beyond rigid conception of national sovereignty. In the cross-border area of good neighborliness a special role has 'little diplomacy' under the influence of the formal framework of relations that manifests itself through it. Positive work in the space of 'small diplomacy' creates security and trust, good neighborliness being expressed as a principle. The border regime, as defined by the literature (Niciu 1999, 246), is determined by each state under its legislation, in accordance with the agreements concluded with its neighbors (Niciu 1999, 246). States aim to ensure their good neighborhood, avoiding border conflicts, without losing sight of the attribute of border sovereignty.

Removing barriers and avoiding the emergence of new lines of division between the enlarged Europe and the new neighbors is the stated aim of the ENP since its launch (Apud Pop, Pascariu, Anglițoiu and Purcăruș, 8). Areas of cooperation are diverse: from politics to economics, from culture to security (Apud Pop, Pascariu, Anglițoiu and Purcăruș, 9). Cross-border cooperation has proven to be a priority of the European Neighborhood Policy. It aims at promoting a coherent and integrated approach to regional development, showing interest in common challenges, guaranteeing efficiency and security at the EU's external borders and encouraging cooperation at local level (Instrumentul european de vecinătate și de parteneriat - Documentul de strategie privind cooperarea transfrontalier $\breve{a ~ 2007-2013, ~}$ Cooperarea transfrontalier $\breve{~ 2007-2013 ~ 2006) . ~}$

In the case of the 2007-2013 EU financial year, the European Union's cross-border cooperation with neighboring countries, including the Republic of Moldova and 
Ukraine, was part of the European Neighborhood and Partnership Instrument. As a member of the EU, Romania was a direct partner of the two European countries within the ENP. This European policy to support the strengthening of political and economic relations with neighboring states has continued to be a priority, being included in the 'cooperation, association and partnership' (Către o nouă politică europeană de vecinătate 2015,2 ). This was in line with the text of the Treaty on European Union which states that 'the Union shall develop privileged relations with neighboring countries with a view to establishing an area of prosperity and good neighborliness based on the values of the Union and characterized by close and peaceful relations based on cooperation' (Article 8 (1)) (Către o nouă politică europeană de vecinătate 2015, 2). Over the 2007-2013 ENP, cross-border cooperation has played an important role in border regions, which are most often confronted with development gaps and socio-economic disparities.

For the 2014-2020 financial year, together with the Eastern or Southern bilateral or regional programs, the European Neighborhood Instrument, rethought in the spirit of the new EU policies, funds cross-border cooperation programs between $M$ ember States and neighboring countries (European N eighbourhood Instrument 20142020 - Programming documents 2017). These programs envisage the financing of cooperation projects between one or more Member States on the one hand and one or more partner countries and / or the Russian Federation on the other hand that run alongside them joint EU external border. Multiannual Joint Operational Programs, which regulate cooperation at a border or a border group, and which contain multi-annual measures designed to respond to a coherent set of priorities that can be implemented with EU support are envisaged. In line with the partnership principle, the actors involved jointly select actions that are likely to benefit from Union support, which are in line with the priorities and measures of the Joint Operational Program.

Through its ENP policies and instruments, the Union offers the countries of its neighborhood a "privileged relationship, based on the mutual commitment to respect and promote the values of democracy, human rights, the rule of law, good governance and the principles of a market economy, such as and sustainable and inclusive growth" (Regulamentul (U E) N R. 232/2014 A L Parlamentului European și al Consiliului din 11 
martie 2014 de instituire a unui instrument european de vecinătate, Jurnalul O ficial al U niunii Europene, $L$ 77/27 2014). The European Union is interested in the success of this neighborhood policy, which it has tried to reform, both at the level of instruments and at program level. In the new sense, EU support is used to benefit partner countries and areas involved in cross-border cooperation through a separate approach but also for the common benefit of the Union and partner countries. The new instruments and regulations give the Russian Federation access to cross-border cooperation, regional cooperation, with the participation of the Union. The Russian State can also be a part of relevant multinational programs, including co-operation in education (Regulamentul (UE) N R. 232/2014 A L Parlamentului European și al Consiliului din 11 martie 2014 de instituire a unui instrument european de vecinătate, Jurnalul O ficial al U niunii Europene, L 77/30).

The geographical eligibility of the new cross-border cooperation programs as part of the European Neighborhood Policy refers to the projects implemented in: a. The land border area covering territorial units corresponding to level 3 of the NUTS $^{1}$ or equivalent across the land borders between Member States and the other countries participating in cross-border cooperation, without prejudice to the potential adjustments necessary to ensure the consistency and continuity of the action to be taken. cooperation; $b$. the maritime border area covering NUTS level 3 territorial units or equivalent located along maritime borders between Member States and other countries participating in cross-border cooperation separated by a maximum distance of $150 \mathrm{~km}$, without prejudice to possible adjustments necessary to ensure the coherence and continuity of the cooperation action; c. a sea basin area covering NUTS 2 coastal territorial units corresponding to NUTS level 2 or equivalent, having an exit to a common maritime basin of the Member States and the other countries participating in cross-border cooperation

${ }^{1}$ See New EU Neighbourhood Policy: the European Neighbourhood and Partnership Instrument (ENPI) and the Instrument for Pre-Accession Assistance (IPA), Association of European Border Regions (AEBR), p. http://www.aebr.eu/files/publications/NeighbourhoodPolicyEN.pdf, accessed in 11.10.2017. 
(Programming of the European Neighbourhood Instrument (ENI) - 2014-2020, 11-12).

The priorities of the cross-border cooperation programs in the current formula are:

1. economic and social development;

2. the environment, public health, safety and security;

3. mobility of persons, goods and capital (Regulamentul (UE) NR. 232/2014 AL Parlamentului European și al Consiliului din 11 martie 2014 de instituire a unui instrument european de vecinătate, Jurnalul O ficial al U niunii Europene, L 77/41). Currently, the EU's neighbouring countries are less stable than they were 10-15 years ago. In the East, European partners have faced serious problems, both internal and above all because of outside peer pressure, including Russia's military pressure. The European Union has been in a position to protect its partners in the face of an increasingly expansive Russian state. The 2008 the Georgian crisis or the current conflict in the Ukraine are eloquent examples about this reality to which the EU had to adapt. In the southern area, Syria has been affected since 2011 by a civil war that has a strong impact on its neighbours. Libya and Egypt experienced deep internal crises. All this have intensified the challenges facing both the EU and its partners, enhancing economic and social pressures, massive, illegal and uncontrollable migration, further enhancing threats to international security.

The premises from which the ENP branches out are different now. In 2013, the EU reviewed its financial instruments in the context of the 2014-2020 multiannual frameworks, including the European N eighbourhood Instrument. Under this new instrument, the European Union's support for its neighbours becomes faster and more flexible, allowing for greater differentiation and incentives ('more for more' - a principle that also includes differentiating among states and stimulating the best performing ones) to the states that are the most committed to adopting reforms and making progress in consolidating deep and sustainable democracy. In spite of the financial crisis and the reduction of the EU's overall budget, the European Neighbourhood Instrument's funding amounts to $€ 15.4$ billion (Comunicare comună către Parlamentul European 2014), which highlights the 
fact that the EU prioritizes its neighbourhood. Up to $5 \%$ of the total amount of the financial envelope is allocated to cross-border cooperation programs.

Through the European Neighbourhood Instrument, which replaced the European Neighbourhood Partnership Instrument, support is given to the implementation of policy initiatives aimed at shaping the ENP, including the Eastern Partnership and the Union for the Mediterranean Sea. Neighbourhood assistance becomes more flexible and faster, reducing the complexity and duration of the programming process so as not to undermine the relevance of assistance (Instrumentul european de vecinătate 2017). In an optimistic forecast, it is considered that in the medium term the ENP will, despite recent difficulties at the EU borders, 'bring stability to the south and integrate in the East' (Apud Pristaș 2015, 61; Lippert 2008, 14).

\section{ROMANIAN-UKRAINIAN CROSS-BORDER COOPERATION. INSTRUMENTS AND RESULTS}

The cross-border cooperation between Romania and Ukraine has been marked by the general framework of bilateral relations, but also by the geopolitical context of the two states. Immediately after the fall of communism and the collapse of the USSR, there were difficulties in cooperation between the young Ukrainian state and the Romanian one. The relationship with Ukraine went through a period of mutual mistrust, so that the two countries have started a process of relaxation of their relations, and as a consequence, the EU has been contributing to it, as well. This cooperation has been marked by legislative and institutional changes stemming from a process of normalization and stimulation of relations with Ukraine, due inter alia to Euro-Atlantic integration. The ENP also contributes to this cross-border mechanism through financial instruments, as well as legislative harmonization on both sides of the EU's external borders. The European Neighbourhood and Partnership Instrument, seen as an incentive in the process of developing relations with the EU's neighbours, was thus able to create bridges at both political, socio-economic, cultural and cross-border level. 
As regards the legislative and institutional framework for facilitating crossborder cooperation, Romania has formally embraced European regulations in this area. In this context of the adoption of this legislation, bilateral and multilateral agreements have intensified. 'Various types of agreements, protocols, international treaties, conventions' have been identified to provide the widest possible regulatory framework and allow cross-border cooperation at local, inter-regional, intergovernmental and multinational level (Roșcovan, Bulat, Puntea and Miron 2010, 42). Different types of intergovernmental agreements, including conventions, protocols and treaties, continue to be part of the basic instruments needed to facilitate cross-border cooperation. The cross-border cooperation relations in Romania and Ukraine are established on the basis of the Treaty of Good Neighbourhood and Cooperation between the two states, signed in Constanta on 2 June 1997 and ratified by Romania by Law 129/1997 (Săraru $2011,89)$. On the basis of this agreement, the two countries subsequently signed several bilateral agreements with an impact on cross-border cooperation.

European policies and directives, including the ENP, converge towards the need to make the cross-border cooperation more effective and bring the exercise of competences as close as possible to citizens. Cross-border cooperation from this perspective is no longer a state policy, but it is transferred to regional, local authorities, regional associations, transnational firms, etc. The regional authorities at the Romanian borders with Ukraine and the development associations play a significant role in shaping and developing cross-border cooperation (Bărbulescu (coord.), Brie and Toderaş 2016, 122). On the basis of the Romanian legislation, regional and local public authorities in border areas 'may conclude cross-border cooperation agreements with similar structures in neighbouring states', leading to the creation of 'bodies that have legal personality according to national law', but without administrative powers ${ }^{1}$. Cross-border cooperation is therefore part of the regional development policy. From this perspective, European and national regional development policies are able to

1 Please see Legea nr. 215 din 23 aprilie $2001\left({ }^{* *}\right.$ republicată $\left.{ }^{* *}\right)\left({ }^{*}\right.$ actualizată*) administrației publice locale (actualizată până la data de 3 iulie 2008*), art. 15, (1), (3). 
stimulate cross-border cooperation, both at the level of legal regulations and in the creation of an institutional framework. This institutional framework is necessary, both at the level of coordination and in the representation of regional interests in front of national or European structures ${ }^{1}$. At the regional level three Euroregions with Romanian-Ukrainian participation were created: the Carpathian Euroregion, the Prutul de Sus Euroregion and the Lower Danube Euroregion (Bărbulescu (coord.), Brie and Toderaş 2016, 123-124; Brie, 2010, 265280).

Cross-border cooperation between Romania and Ukraine has been achieved through European instruments and mechanisms. The financial period 2007-2013 coincides with the first years after Romania's accession to the EU, and in its new quality, the Romanian state became an active and interested ENP promoter. Thus, through the ENPI, cross-border cooperation at Romania's borders with Ukraine was financed through Hungary-Slovakia-Romania-Ukraine Crossborder Operational Program; The Romania-Ukraine-Moldova Cross-Border Cooperation Operational Program, respectively the Black Sea Basin Operational Program. In addition to these programs aimed at explicit and direct support for cross-border cooperation, this was also supported by other European programs for the integration and development of the EU-Ukraine border areas.

The Operational Program for Cross-Border Cooperation Romania-UkraineRepublic of Moldova had a total budget of 138,122,693 euros for the seven years of programming at its launch. Of this amount, the EU contribution through the ENPI is $126,718,067$ euros, while the partner states have had to participate in financing projects with a total co-financing of approximately 11,404,626 euros (Programul Operațional Comun România-U craina-M oldova 2007-2013 2008, 81). The strategy of the program has been established in line with the four ENPI general objectives in the field of cross-border cooperation: 1. promoting a sustainable economy and social development; 2 . Joint solving of environmental, security and

1 Transnational regional associations become promoters of the decentralization and application of the European subsidiarity principle. An example for this can be the European Association of Border Regions (AEBR) founded in 1971. Mihai Roșcovan, Veaceslav Bulat, Mariana Puntea, Viorel M iron, op. cit., p. 15. 
public security issues or prevention and fight against organized crime; 3 . secure and efficient border management; 4. promoting "people-to-people" activities (Programul Operațional Comun România-U craina-M oldova 2007-2013 2008, 4). Against this background the specific objectives of the program were set: "1. Stimulate economic and social development in the program area and adjacent areas; 2. Addressing environmental issues in the border area and ensuring a high level of preparedness for emergencies; 3. Encouraging contacts and cooperation between the inhabitants of the border areas" (Programul Operațional Comun România-U crainaRepublica Moldova ENPI CBC 2007-2013). The eligible area of the program, covering a territory of 176.6 square kilometres, consists of regions belonging to the three neighboring states, respectively the counties of Botoşani, Galați, Iaşi, Suceava, Tulcea and Vaslui in Romania, the Odessa and Chernovtsy regions of Ukraine, and the whole territory of the Republic of Moldova. Besides these regions, the program also includes at the suggestion of the states, some adjacent regions, which 'can positively influence border co-operation'. In this category were included: "the Romanian county of Braila, the U krainian regions Ivano Frankivska, Vinniytska, ten districts in the Khmelnytska region and twelve districts in Ternopilska" (Programul O perațional Comun România-U craina-Republica M oldova 2007-2013 2017). Eligible beneficiaries of this program were "regional and local public authorities, non-governmental organizations, associations, universities, research institutes, educational / training organizations, etc." (Programul O perațional Comun România-U craina-Republica M oldova 2007-2013 2017). The variety of these eligible beneficiaries is larger and takes into account the specificity of each priority, their list being announced at each call. Applicants must be associated in a partnership, including at least two partners on both sides of the border. One of the partners must be from Romania, and at least one partner from the Republic of Moldova and / or Ukraine (Joint Operational Programme Romania-U kraine-Republic of M oldova 2007-2013. Guidelines for Grant A pplicants 2017, 14).

One year after the program was approved by the European Commission, the first call for projects (the second half of 2009) was launched. Its budget was EUR 30 
million for the first two priorities and for the third priority of EUR 5 million ${ }^{1}$. The deadline for projects submitted under Priority 3, being smaller projects, was September 28, 2009, and for the larger ones submitted on Priority 1 and Priority 2 was October 28, 2009 (Joint Operational Programme Romania-U kraine-Republic of Moldova 2007-2013. Guidelines for Grant Applicants 2017). During the project submission period, 422 applications were registered and the requested budget was 320 million euro (Ghinea and Toma 2013, 7). Of these, 112 were applicants from Moldova and 382 proposals were received from Moldovan partners compared to 247 in Ukraine and 375 in Romania (Programul O perational Comun România-U craina-M oldova 2007- 2013- proiecte deinteres strategic aflate pe agenda comună, stadiu, obstacole in implementare 2013, 5). Due to the lack of instruments, procedures, institutional changes and political changes, the evaluation period for funding applications was very high. This was basically the first exercise on this program, both for the Romanian authorities and for the Moldovan and Ukrainian partners. The first Priority 3 contracts were signed only at the beginning of 2011 and those on Priority 1 and 2 only in October 2011 (2 years after the submission of projects) (Dinu, Gamurari 2013,4). Following this first call for projects, a total of 85 winning applications totaling $€ 34,507,722.36^{2}$ were contracted to finance.

The second call for projects, which was opened for applications in November 2011, had a deadline for submission of projects January 30, 2012 (A nunt privind lansarea celui de-al doilea apel de propuneri de proiecte 2010). Up to which 1,060 applications have been registered (1.060 de note conceptuale depuse in cadrul apelului 2 pe Programul Romania-Ucraina-Republica Moldova 2012), 272 being applicants from Moldova, 141 Ukraine and 637 from Romania. On an absolute level, the number of projects doubled in the second period, indicating a growing interest of the participating countries, but at the systemic level much more was

1 With the approval of the JCC, the possibility of extending the budget for this call according to needs was foreseen, the interest identified for each priority, as well as the identification of valuable projects.

2 The complete list of the financed projects can be seen here: http://www.ro-uamd.net/proiecte-3/proiecte-contractate/proiecte-contractate-apelul-1/, accessed in 14.08.2017. 
needed (Programul Operațional Comun România-U craina-M oldova 2007- 2013proiecte deinteres strategic aflate pe agenda comună, stadiu, obstacole în implementare 2013, 5). According to the list of projects presented on the official website of the program, in the second call, 50 winning applications worth a total of EUR $35,602,720.65^{1}$ were contracted for funding, plus the co-financing part.

In addition to applications that received funding from the two calls for projects, a total of 8 major investment projects worth $44,173,979.55$ euros $^{2}$ were selected for the three program priorities, plus the co-financing part. These projects are the result of identifying major special needs by the representatives of the three partner countries. Analysing the 8 major investment projects, we find that half of them are implemented in all three Member States of the program, 3 are implemented in Romania and Moldova and only 1 in Romania and Ukraine. In 4 cases, project leaders are institutions in Romania, and in 2 cases they are from the Republic of Moldova and Ukraine. Moldova is part of 7 projects, while Ukraine is in only 5 out of 8 major investment projects. Beyond the privileged position of Romania (as a member of the EU was ensured presence in all cross-border projects), the Republic of Moldova is the main beneficiary of these investments, also taking into account the size of grants to projects involving institutions in this country. We consider, however, that an important factor contributing to this position was the privileged relationship with Romania, plus the financial support granted by the Romanian state for the implementation of these projects.

${ }^{1}$ See the full list of contracted projects as well as the financial allocations for the project, available on the program's website http://www.ro-ua-md.net/proiecte3/proiecte-contractate/proiecte-contractate-apelul-2/, accessed in 11.10.2017.

2 The list of these projects can be consulted on the official website of the program, http://www.ro-ua-md.net/proiecte-3/proiecte-contractate/proiecte-majore-deinvestitii/, accessed in 07.10.2017. 


\section{List of the major investment projects}

\begin{tabular}{|c|c|c|c|c|c|}
\hline No. & Beneficiary & Country & $\begin{array}{l}\text { Country/Region } \\
\text { of } \\
\text { implementation }\end{array}$ & $\begin{array}{l}N \text { ame of } \\
\text { project/intervention }\end{array}$ & $\begin{array}{l}\text { Value } \\
\text { the } \\
\text { European } \\
\text { financing } \\
\text { (EUR) }\end{array}$ \\
\hline 1 & $\begin{array}{l}\text { Customs } \\
\text { Service of } \\
\text { the } \\
\text { Republic } \\
\text { of } \\
\text { Moldova }\end{array}$ & MD & $\mathrm{RO}, \mathrm{MD}$ & $\begin{array}{l}\text { IMPEFO - Improve the } \\
\text { cross-border } \\
\text { cooperation between the } \\
\text { Republic of Moldova } \\
\text { and Romania in the } \\
\text { field of oil and food } \\
\text { products }\end{array}$ & $3.094 .194,60$ \\
\hline 2 & $\begin{array}{l}\text { Ministry of } \\
\text { Internal } \\
\text { Affairs } \\
\text { General } \\
\text { Inspectorate } \\
\text { for } \\
\text { Emergency } \\
\text { Situations }\end{array}$ & & $\mathrm{RO}, \mathrm{MD}$ & $\begin{array}{l}\text { Improvement of Mobile } \\
\text { Service for Emergency, } \\
\text { Resuscitation and } \\
\text { Extrication (SMURD) } \\
\text { response capacity } \\
\text { through an integrated } \\
\text { system for effective } \\
\text { monitoring and } \\
\text { mitigation of disaster } \\
\text { consequences for the } \\
\text { population located } \\
\text { between the common } \\
\text { borders of Romania, } \\
\text { Ukraine and the } \\
\text { Republic of Moldova }\end{array}$ & 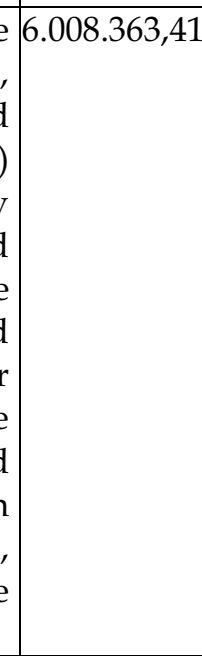 \\
\hline 3 & $\begin{array}{l}\text { National } \\
\text { Agency for } \\
\text { Mineral } \\
\text { Resources }\end{array}$ & RO & RO, MD & $\begin{array}{l}\text { Gas pipeline for the } \\
\text { interconnection of the } \\
\text { natural gas } \\
\text { transmission system in } \\
\text { Romania and the } \\
\text { Moldovan gas } \\
\text { transmission system } \\
\text { from Iasi (Romania) - }\end{array}$ & \begin{tabular}{|l}
$7,000,000.00$ \\
\\
\\
5
\end{tabular} \\
\hline
\end{tabular}




\begin{tabular}{|c|c|c|c|c|c|}
\hline & & & & Ungheni (Moldova) & \\
\hline 4 & $\begin{array}{l}\text { Department } \\
\text { of } \\
\text { Environme } \\
\text { nt and } \\
\text { Natural } \\
\text { Resources } \\
\text { of the State } \\
\text { Regional } \\
\text { Administrat } \\
\text { ion of } \\
\text { Odessa }\end{array}$ & UA & $\mathrm{UA}, \mathrm{MD}, \mathrm{RO}$ & $\begin{array}{l}\text { Inventory, evaluation } \\
\text { and remediation of } \\
\text { sources of } \\
\text { anthropogenic } \\
\text { pollution in the Lower } \\
\text { Danube Region } \\
\text { between Ukraine, } \\
\text { Romania and the } \\
\text { Republic of Moldova }\end{array}$ & $5.181 .782,42$ \\
\hline 5 & $\begin{array}{l}\text { Ministry of } \\
\text { Economy } \\
\text { of the } \\
\text { Republic } \\
\text { of } \\
\text { Moldova }\end{array}$ & MD & $\mathrm{MD}, \mathrm{UA}, \mathrm{RO}$ & $\begin{array}{l}\text { Feasibility Study for } \\
\text { Synchronous } \\
\text { Interconnection } \\
\text { between Power Supply } \\
\text { Systems in Ukraine and } \\
\text { the Republic of } \\
\text { Moldova with the } \\
\text { ENTSO-E European } \\
\text { Continental Power } \\
\text { Transmission System } \\
\end{array}$ & 6.360.639,12 \\
\hline 6 & $\begin{array}{l}\text { Ministry ofl } \\
\text { Transport } \\
\text { and } \\
\text { Infrastructur } \\
\text { e, Romania }\end{array}$ & & RO-UA-MD & $\begin{array}{l}\text { Cross-Border } \\
\text { Infrastructure } \\
\text { (Communications } \\
\text { Infrastructure between } \\
\text { Romania, Ukraine and } \\
\text { the Republic of } \\
\text { Moldova) }\end{array}$ & 4.700 .000 \\
\hline 7 & $\begin{array}{ll}\text { Ministry } & \text { of } \\
\text { Finance } & \text { of } \\
\text { Ukraine } & \end{array}$ & & UA-RO & $\begin{array}{l}\text { Strengthening the } \\
\text { border infrastructure by } \\
\text { modernizing the } \\
\text { customs crossing points } \\
\text { between Ukraine and } \\
\text { Romania }\end{array}$ & 3.500 .000 \\
\hline
\end{tabular}




\begin{tabular}{|l|l|l|l|}
\hline 8 & $\begin{array}{l}\text { Ministry of } \\
\text { Environme } \\
\text { nt and } \\
\text { Climate } \\
\text { Change, } \\
\text { Romania }\end{array}$ & RO-UA-MD & $\begin{array}{l}\text { Prevention and } \\
\text { protection against } \\
\text { floods in the rivers Prut } \\
\text { and Siretul de Sus by } \\
\text { implementing a modern } \\
\text { monitoring system with } \\
\text { automatic stations - } \\
\text { EAST AVERT }\end{array}$ \\
\hline
\end{tabular}

Source: Official website of the program, http://www.ro-ua-md.net

For the purpose of streamlining and facilitating implementation during the 20142020 period, a special program was created for cross-border cooperation between Romania and Ukraine, the Joint Operational Program Romania-Ukraine, fed by the EU through the European Neighbourhood Instrument (ENI). The program addresses the border area between Romania and Ukraine and will contribute to the overall objective of the European Neighbourhood Instrument: the evolution towards a region of prosperity and good neighbourliness through cross-border cooperation actions for the benefit of Member States and non-EU members in the adjoining area (Romanian Ministry of European Funds 2017). The eligible area of the program includes the Romanian counties: Botoşani, Suceava, Tulcea, Maramureş, Satu-Mare, and the Ukrainian regions: Odessa, Ivano-Frankivsk, Zakarpatska, Cernăuți. The budget of this program is $€ 66$ million (66 million total budget - of which 60 million are funded by the EU through the European Neighbourhood Instrument - ENI and 6 million euro co-financed by partner countries).

\section{CONCLUSIONS}

The relations between Romania and Ukraine have seen many changes over the last two decades. They were marked by an increasingly visible opening, generated by normalization of the bilateral relationship, but also due to the process of European integration. Upon joining the European Union, the Romanian border with Ukraine has become an external border of the EU, with all 
the consequences arising from this reality. Cross-border cooperation at the Romanian-Ukrainian border is part of the overall parameters of the European Neighborhood Policy, being supported, including financially, by the European mechanisms. Then geopolitically Ukraine has become an increasingly interesting area for the EU. The conflicts in eastern Ukraine, Russia's interference in these conflicts, have complicated this process. The EU message to Ukraine is one of openness; however cooperation has become more complex, with the Ukrainian state having to reset its internal priorities, including its regional development at the western borders.

In particular, the Romanian-Ukrainian bilateral relations have been influenced by the historical and demographic realities at the borders. The presence of a large Romanian community in Ukraine, as well as of a Ukrainian community in Romania, was often a decisive element in stimulating this cooperation.

There are still many impediments to this cross-border cooperation. They are equally related to domestic political realities and to the wider geopolitical context. At the legislative level, we often find discrepancies and gaps that prevent the implementation of initiatives promoted by the European Union. These realities are then determined by the significant differences of administrative nature, by the competences of local and regional authorities. Last but not least, we note that the process of cross-border cooperation can be influenced by the level of political will, by the general framework of bilateral relations. Such cooperation may be accompanied by legislative measures or political actions that run counter to the interests of the partners. An example of this is the new education law approved by Kiev which provides for the gradual implementation of Ukrainian education in national minority schools (including Romanian). The prospects for cross-border cooperation depend then on factors external to the bilateral relationship, the positions and new geopolitical realities. 


\section{REFERENCES}

- Anunț privind lansarea celui de-al doilea apel de propuneri de proiecte [A nnounce regarding the second call for projects proposals], Programul Operațional Comun România - Ucraina - Republica Moldova 2007 - 2013 (The Common Operational Programme Romania-Ukraine-Moldova 2007-2013), http://www.mdrap.ro/userfiles/ro_uk_mo_anunt_apel2.pdf, accessed in 11.10.2017.

- Bărbulescu, Iordan Gheorghe (coord.); Brie, Mircea and Toderaş, Nicolae. 2016. Cooperarea transfrontalieră între România şi Ucraina, respectiv între România şi Republica Moldova. Oportunități şi provocări între 2014-2020 [Crossborder cooperation between Romania-U kraine, Romania-Republic of M oldova 2014-2020], Tritonic, Bucureşti, 2016

- $\quad$ Bărbulescu, Iordan Gheorghe. 2015. Noua Europă. Identitate şi model European [The N ew Europe. Identity and the European model], Polirom, 2015

- $\quad$ Brie, Mircea and Blaga, Daniela. 2015 Identity rematch in the European space, in Cultural Diplomacy at the East and West Borders of the European U nion, 2015.

- Brie, Mircea, Horga, Ioan. 2009. The Romanian-U kranian Cross-Border Cooperation an The European Instruments, în U craina- Romania- M oldova: aspecte istorice, politice si culturale ale relatiilor in contextul proceselor europene contemporante, vol. 3, Cernăuți, 2009, p. 302-318

- Brie, Mircea. 2009. The European Neighborhood Policy, M ass-media and Cross-border Cooperation, in Analele Universității din Oradea, Seria Relații Internaționale şi Studii Europene, 2009, p. 81-86

- Brie, Mircea. 2009. The European Neighborhood Policy, M ass-media and Cross-border Cooperation, in Analele Universității din Oradea, Seria Relații Internaționale și Studii Europene, 2009, p. 81-86.

- $\quad$ Brie, Mircea. 2010. Europe from Exclusive Borders to Inclusive Frontiers: Case Study Romanian - U krainian Frontier, in Ioan Horga, Istvan Suli-Zakar (coord.), Cross-Border Partnersip with Spacial Regard to the Hungarian-Romanian-U krainian Tripartite Border, Oradea-Debrecen, 2010, p. 23-36.

- $\quad$ Brie, Mircea. 2010. European Instruments of Cross-border cooperation. Case study: the Romanian-U krainian border, in Identités, citoyennetés et démocratie, 20 ans après, sous la direction de Fabienne Maron, Grzegorz Pozarlik, Editions Bruylant, Bruxelles, 2010, p. 265-280 
- $\quad$ Brie, Mircea. 2017. A N ew European N eighbourhood Policy toward U kraine and the Republic of Moldova in the Context of the Eastern Partnership (EaP) and the A ssociation A greements (A A), in Studii Europene, no. 10, Chisinău, 2017, p. 123-155. - Către o nouă politică europeană de vecinătate [Towards a new European N eighbourhood Policy], Document comun de consultare, Comisia Europeană, Înaltul Reprezentant al Uniunii Europene pentru Afaceri Externe și Politica de Securitate, Bruxelles, 4.3.2015 JOIN(2015) 6 final, http://ec.europa.eu/enlargement/neighbourhood/consultation/consultation_r omanian.pdf, accessed in 11.10.2017.

- $\quad$ Comisia Europeană, Înaltul Reprezentant al Uniunii Europene pentru Afaceri Externe și Politica de Securitate, Comunicare comună către Parlamentul European, Consiliu, Comitetul Economic și Social European și Comitetul Regiunilor. Politica de vecinătate la răspântie: punerea în aplicare a politicii europene de vecinătate în 2013, [Common Communication to the European Parliament, the Council, The European Ecomonic and Social Committee] EUR-Lex, Access to European Union law, http://eur-lex.europa.eu/legalcontent/RO/TXT/PDF/?uri=CELEX:52014JC0012\&from=RO, accessed in 12.10.2017.

- $\quad$ Convenția-cadru europeană privind cooperarea transfrontalieră a colectivităților sau autorităților teritoriale [The European Conventioin regarding the crossborder cooperation of colectivities or teritorial authorities], Madrid, 21 mai 1980, http://conventions.coe.int/Treaty/EN/Treaties/PDF/Romanian/106Romanian.pdf, accessed in 06.10.2017.

- Cooperare transfrontalieră [Crossborder Cooperation], http://transeco.ecosv.ro/cooperare_trans_ro.htm, accessed in 22.08.2017.

- Costea Ana Maria. 2015. East versus West, When Politics collide with economics, Tritonic, 2015

- Dinu, Dragos;; Gamurari, Ludmila. 2013. The Joint O perational Program Romania - U kraine - Republic of Moldova. Current challenges and further developments, Policy Memo, nr. 36, CRPE, A new framework for better cooperation: Romania-U kraine-M oldova, Centrul Român de Politici Europene, February 2013, p. 4, http://www.crpe.ro/wp-content/uploads/2013/02/Trilaterala-romaniaucraina-ok.pdf, accessed in 12.10.2017.

- $\quad$ EUR-Lex, Access to European Union law, Instrumentul european de vecinătate și de parteneriat - D ocumentul de strategie privind cooperarea transfrontalieră 2007-2013 [The European Instrument of N eighbourhood and Partnership- The Strategic Document regarding the crossborder cooperation 2007-2013], Crossborder 
cooperation 2007-2013-Sinthesis, http://eur-lex.europa.eu/legalcontent/RO/TXT/HTML/?uri=URISERV:r17104\&from=RO, accessed in 11.10.2017.

- EUR-Lex, Access to European Union law, Regulamentul (UE) NR. 232/2014 A L Parlamentului European și al Consiliului din 11 martie 2014 de instituire a unui instrument european de vecinătate [EU Rule No.232/2014 of the European Parliament and of the Council frim $11 \mathrm{M}$ arch 2014 regarding the European instrument of Neighbourhood], Jurnalul Oficial al Uniunii Europene, L 77/27, 15.03.2014, http:/ / eur-lex.europa.eu/legalcontent/RO/TXT/?uri=uriserv:OJ.L_.2014.077.01.0027.01.RON, accessed in 30.09.2017.

- Europa in direct. Cooperare transfrontalieră [Europelive. Crossborder cooperation], http://europaindirect.ecosv.ro/cooperare_trans.htm, accessed in 14.09.2017.

- $\quad$ European Union, External Action, European Neighbourhood Instrument 2014-2020 - Programming documents, http:/ / eeas.europa.eu/enp/documents/financing-the-enp/index_en.htm, accessed in 19.09.2017.

- Ghinea, Cristian; Toma, Bianca. 2013. Bune practici în relația România Republica M oldova. M odele de parteneriat [Good practices regarding the relationship between Romania and the Republic of M oldova. Partnership models], Policy Memo, nr. 47, CRPE, September 2013, http://www.crpe.ro/wpcontent/uploads/2013/10/policy-memo-47-crpe-Moldova-Bune-Practici-raportfinal.pdf, accessed in 11.10.2017.

- Gruszczak, Artur. 2010. „The securitization of the Eastern borders of the European Union. Walls or bridges?', (paper to the UACES 40th Annual Conference Exchanging Ideas on Europe: Europe at a Crossroads, Bruges, 6-8 September 2010), http://www.uaces.org/pdf/papers/1001/gruszczak.pdf accessed in 11.10.2017

- $\quad$ Hubeny-Berlsky, Annabelle. 2007. Le financement de la PEV - la réponse proposée (1), in Laurent Beurdeley, Renaud de La Brosse, Fabienne Maron (coord.), L'U nion Européenne et ses espaces de proximité. Entre stratégie inclusive et parteneriats removes: quell avenir pour le nouveau voisinage de I'U nion?, Bruxelles, Bruylant, 2007.

- Instrumentul european de vecinătate [The European Neighbourhood Instrument], European Moldova, Recourses Centre 'DIALOG-PRO', 
http://infoeuropa.md/instrumentul-european-de-vecinatate/, accessed in 11.09.2017.

- Joint Operational Programme Romania-U kraine-Republic of M oldova 20072013. Guidelines for Grant A pplicants, Priority 1 - Towards a more competitive border economy and Priority 2 - Environmental challenges and emergency preparedness, http://www.mdrap.ro/dezvoltare-regionala/-2257/ programe-de-cooperareteritoriala-europeana/-3696, accessed in 11.10.2017.

- $\quad$ Legea $\mathrm{nr} .215$ din 23 aprilie $2001\left(^{(* *}\right.$ republicată $\left.{ }^{* *}\right)\left({ }^{*}\right.$ actualizată$\left.{ }^{*}\right)$ administratiei publice locale [Law no 215 from 23 A pril 2001 of the Local Public Administration] (updated till 3 July 2008*)

- Matuszewicz, Régis. 2007. Vers la fin de l'Élargissement?, in Laurent Beurdeley, Renaud de La Brosse, Fabienne Maron (coord.), L'U nion Européenne et ses espaces de proximité. Entre stratégie inclusive et parteneriats removes: quell avenir pour le nouveau voisinage de I'U nion?, Bruxelles, Bruylant, 2007.

- Ministerul Fondurilor Europene/România, http://www.fonduriue.ro/ro-ua\#contact-am-ro-ua, accessed in 19.10.2017.

- $\quad \quad \quad \quad$ ew EU N eighbourhood Policy: the European N eighbourhood and Partnership Instrument (ENPI) and the Instrument for Pre-Accession Assistance (IPA), Association of European Border Regions (AEBR), p. 5, http://www.aebr.eu/files/publications/NeighbourhoodPolicyEN.pdf, accessed in 11.10.2017.

- Niciu, Marțian. 1999. Drept internațional public [Internatinal Public Law], Ed. Servosat, 1999.

- $\quad$ Perepelytsia, Grygoriy. 2010. 'Capacity of instruments for development of mutually beneficial relations in the format 'Uraine-Visegrad Plus,' volume of the International Conference: U kraine and the Visegrad Four: Towards a M utually Beneficial Relationship, May 13-14, 2010.

- $\quad$ Policy Memo, nr 46, Romanian Centre for European Policies, August 2013, http://www.crpe.ro/wp-content/ uploads/2013/08/Policy-Memo-CooperareRegionala-FINAL.pdf accessed in 20.09.2017.

- $\quad$ Policy Memo, nr 46, Romanian Centre for European Policies, August 2013, http://www.crpe.ro/wp-content/uploads/2013/08/Policy-Memo-CooperareRegionala-FINAL.pdf accessed in 11.10.2017.

- Pop, Adrian; Pascariu, Gabriela; Anglițoiu, George and Purcăruș, Alexandru. România și Republica M oldova - între Politica Europeană de Vecintate și perspectiva extinderii U niunii Europene [Romania and the Republic of M oldova-between the European Neighbourhood Policy and the enlargement of the European Union], 
European Institute from Romania - Studii de impact III, , http://www.ier.ro/sites/default/files/pdf/Pais3_studiu_5_ro.pdf, accessed in 11.10.2017.

- $\quad$ Pristaș, Alina Ioana. 2008. Implicarea României în Politica de vecinătate a Uniunii Europene [the Engagement of Romania within the European N eighbourgood Policy], PhD thesis, Babeș-Bolyai University, Cluj-Napoca, 2015, Barbara Lippert, European Neighbourhood Policy: Many reservations - some progress - uncertain prospects, June 2008

- $\quad$ Programming of the European N eighbourhood Instrument (ENI) - 2014-2020, Programming document for EU support to EN I Cross-Border Cooperation (2014-2020), http://eeas.europa.eu/enp/pdf/financing-the-enp/cbc_20142020_programming_document_en.pdf, accessed in 11.10.2017.

- Programul Operational Comun România-U craina-M oldova 2007-2013 [The Common $O$ perational Programme Romania-U kraineM oldova 2007-2013] (2008 version), , http://www.mdrl.ro/_

documente/coop_teritoriala/granite_externe/ro_uk_mo/POC\%20Ro-UaMd\%2029\%20feb\%20romana.pdf, accessed in 11.10. 2017.

- $\quad$ Programul Operațional Comun România-U craina-Republica M oldova 20072013 - finanțat din ENPI [The Common Operational Programme Romania-UkraineM oldova 2007-2013-financed through ENPI], http://www.mdrap.ro/dezvoltareregionala/-2257/ programe-de-cooperare-teritoriala-europeana/-3696, accessed in 11.10.2017.

- Programul Operațional Comun România-U craina-Republica M oldova ENPI CBC 2007-2013 [The Common O perational Programme Romania-U kraine-M oldova 2007EN PI CBC 2013], Secretariatul Tehnic Comun, Biroul Regional pentru Cooperare Transfrontalieră Suceava pentru Granița România-Ucraina, http://www.brctsuceava.ro/ pagini/ programul-operational-comun-enpi-cbc2007-2013/ro-ua-md/obiective-i-priorit-i-1.html, accessed in 11.10.2017

- $\quad$ Ricq, Charles. 2000. Manual de cooperare transfrontalieră pentru uzul colectivităților locale și regionale în Europa [Crossborder cooperation manual for the use of local and regional colectivities in Europe)], the $3^{\text {rd }}$ edition, Bucharest, 2000.

- Roșcovan, Mihai; Bulat, Veaceslav; Puntea, Mariana and Miron, Viorel. 2010. Ghid de cooperare transfrontalieră [Crossborder Cooperation Guide], Second edition, Chișinău, 2010.

- Săraru, Cătălin-Silviu. 2011. „Considérations sur les accords de coopération transfrontalières entre les unités administratives-territoriales limitrophes des zones 
frontalières de la Roumanie et les structures similaires dans les pays voisins', in 'Curentul Juridic' nr. 2(45)/2011.

- $\quad$ Strategia de dezvoltare a judetului Satu Mare până în 2020. COM PAS 20 Concepții și O rientare M odernă, Planificare A rmonioasă și Strategică până în 2020 [The Development Strategy of Satu M are county until 2020. COM PAS 20-Cencepts and Modern Direction. Harmonious and Strategic Planning until 2020], Chapter 8. Crossborder Cooperation, file:/ / C:/Documents\%20and\%20Settings/MirceaB/My\%20Documents/Downl oads/CAPITOLUL $\% 208 \% 20$ -

\%20COOPERARE\%20TRANSFRONTALIERA\%CC\%86_1.pdf, accessed in 04.10.2017. 


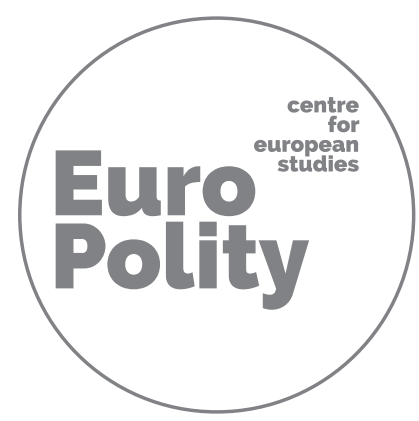




\title{
AGENT-CHANGE RELATION: EU MEMBERSHIP AND THE NEW DYNAMICS OF ROMANIAN PUBLIC ADMINISTRATION
}

\author{
Cristina-M aria D ogot \\ University of Oradea \\ Oradea, Romania \\ cdogot@uoradea.ro
}

\begin{abstract}
The first years after 1989, Romanian public administration seemed not to be influenced by the political changes, in the sense of organisational reform. Only in the eve of Romania's accession to European Union, and especially since 2000, when the process of negotiation with the EU officially started, the field of public administration began to be in a higher extent considered for reform. From the end of the nineties to the present time it is possible to reveal two stages of changes related to public administration: those provoked from top down, related to the process of accession to $\mathrm{EU}$, and those from bottom up, related to the process of integration in the EU. The main hypothesis of the article is that EU acted as a direct pressure factor / agent of change in what concerns the organisational reform of Romanian public administration realised during the pre-accession period, while it abandoned this direct role after accession (with some negative consequences). The aim of the present paper is to analyse the dynamic of Europeanisation of Romanian public administration in pre-accession and post-accession periods from the perspective of the organisational reform, realised by adopting the related necessary internal norms according to the Acquis Communautaire.
\end{abstract}




\section{Keywords}

Dynamic of change, Europeanisation, public administration, reform

\section{INTRODUCTORY REMARKS}

The way to (re)organise the public administration of the former communist states, even in different degrees, represented an important challenge both from an internal perspective (how to report to the issue of reform) and from that of accession and integration into a so original and complex supranational organisation as the European Union is. Although not so dramatic in their effects, the first modifications related to the way in which the work of the Romanian administrative system were adopted in 1991, by the new Constitution. Hence, this stipulated "the principle of local autonomy and of decentralisation of public services" (art. 119) and the "autonomous administrative authorities" (art. 120), but for latter it was possible to be established only by organic law (art. 116/3). Although the necessity of reform and modernisation of public administration was experienced from the beginnings ${ }^{1}$, the recently concluded communist period will continue to influence the process of modernisation oriented towards some results as democratisation, transparentisation, debureaucratisation, amongst others. Given the fact that after the end of communism the public administration preserved the majority of its professionals and the same type or hierarchical and functional structures it will be long-time perceived as a very useful instrument that could be legally used by politics (Hințea and Șandor 2000, 30) to impose its decisions, especially that the new political elite was largely represented by a majority of the former communist activists, some of them with a dissident activity overshadowed by some previous political actions related to the

1 "at their beginning after $1989 \ldots$ all the reforms focused mainly on the establishment/re-establishment of basic democratic administrative values and principles." (Bouckaert, Nakrošis, and Nemec 2011, 16) 
communist state ${ }^{1}$ (Pasti 1995, 123; Hințea, Șandor and Junjan 2002, 55-57; Șandor and Hințea 1999; Șuta 1998;). The positive effect of a given efficiency provided by this professional continuity was outclassed by the adverse results: administrative structures maintained the old administration-citizen relations, namely of citizen subordination and domination by administrative structures, and not the opposite, beside the inability or even unwillingness to provide quality services to citizens, according to the specific duties of any administration ${ }^{2}$ (Pasti 1995, 123126, 144-149; Goetz 2001, 1032-1033). As it is possible to see in the following section, only by the late nineties, under the influence of the approaching commencement of the process of the EU accession negotiations ${ }^{3}$, some very important laws related to the interference between public administration and citizens were adopted; nonetheless, in the process of acquiring the membership of the Council of Europe and due to various external financial support, Romania had to adopt some decisions regarding the reform of many fields of public activity, public administration included (Aderarea României; Instrumente juridice; Warner et al.; Hințea, Șandor, and Junjan 2002, 59sqq; Goetz 2001, 1034). At the same time, some elements related to the functional tools and methods to assess the activities of public administration imposed as intrinsic to use in order

${ }^{1}$ For these reasons Goetz (2001, 1038-1043) considered the difficulties in modernising the Eastern European states mainly as a result of their communist legacies, estimated the depoliticisation as "a central plank of administrative reform in the region", and reccomended more conditionalities for the EU accession of the Eastern European states. 2 They are many studies (Popa 2017; Hințea and Neamțu 2014/2015; Săgeată 2012; Berceanu 2012; Hudrea 2014; Moldovan and Macarie 2016) reaching the matter of relations between public administration and citizens as its main beneficiaries or some disfunctionalities and failures of the public administration in its policies concerning regionalisation and/or decentralisation.

${ }^{3}$ This is why some specialists consider that Romania began the reform of its public administration only under the influence of the process of accession to EU and that all the previous adopted norms and changes are insufficient to discuss about reform or modernisation (Tudorel, Profiroiu, and Turturean 2006, 55; Șandor and Tripon 2007, 93$94,100)$. 
to deal with the challenges of Europeanisation process $^{1}$ and its intrinsic conditionalism. Hence, some functional principles as performance, results-based management, leadership skills, the balance between costs and resources, efficiency and effectiveness, transparency, accountability, professionalism (SIGMA-OECD 1998; Nakrošis 2014, 3) were at least formally adopted by the new operational programmes and strategies of reform and modernisation/Europeanisation of the Romanian public administration.

It is well known that the matter of national public administrations does not represent one of the exclusive competencies of the $\mathrm{EU}^{2}$ (but one to support the

${ }^{1}$ Understood in various acceptations, the means that I considered for this paper refer to Europeanisation as process of modification of national laws by adopting the Acquis Communautaire; as a process of modification of the working principles of various public institutions or economic entities according to EU's formal requests; the process of modification of the principles of conduct and action of various institutions and society through voluntary acquisition of European institutional models (Knill 2001; Radaelli $2004)$ or, as Attila Ágh $(2013,741)$ said, of “'domestication' of the European system of democratic institutions", usually with the aim of a future accession to the EU (Goetz 2001, 1037-1038). If usually EU is considered the agent of Europeanisation of different structures and societies, as in a spill-over mechanism, the Romanian public administration in its turn was perceived by EU as an agent of Europeanisation, by the requests of its transformation in a tool "of implementation of European norms" able „to develop the necessary mechanisms to support the participation and to coordinate the activities of Romanian officials in the structures of European Union". This demand will produce some given structural, procedural and content modification of its public policies (Bosovcki 2009), though the process will be a difficult one, with some noticeable failures (Berceanu 2012, 957; Nakrošis 2014, 3-5).

2 The EU was directly interested in reforming this field of activity, given to its major role in applying the acquis communautaire and, not less important, in the general stability and development of economic, social, and cultural environments, the creation of some public values and promotion of democratic principles. (European Commission 2016) On the other side, as for other domains too, the EU was never completely alone in monitoring and supporting the process of reforms in public administration, some other supranational institutions being financially involved in supporting this process: World Bank, International Monetary Fund, OECD (Bouckaert, Nakrošis, and Nemec 2011, 13; Goetz 2001, 1035). 
actions of $\mathrm{MS}^{1}$ ), and because of this fact this field of national activities was not included in a separate chapter of negotiations ${ }^{2}$ and the process of reform was

1 From this perspective it is possible to consider the "structural closure" (Battilana and Casciaro 2012, 383-387) between the EU and its MS as being not so high to provide to the EU a direct causal role of an agent of change (or a „principal-agent," according to Pollack (2005)) in the Romanian administrative field, but one that allotted to Romania, as a candidate State, the possibility to adapt the EU's requests to its particularities. Nonetheless, the analysis of the accession period demonstrate the role and influence of the EU's conditionalism in improving and moving on some processes that, probably, otherwise would have taken much more.

2 However, the consultation of position documents related to all the chapters of negotiations revealed references to the public administration officials, decisions, in the following chapters: 1, Free movement of goods, in relation to the matter of public procurement and the process of monitoring the public free movement of chemical substances and preparations dangerous to humans and the environment; $\mathbf{3}$, Free movement of services, in relation to the necessity of e-government "to ensure the rapid access of citizens and companies to government services"; 5, Companies law, in relation to the training of specialists from public administration in the field; 6, Competition policy, in relation to the role of public administration units in providing the necessary local regulations for the emergence of market competition concerning the local public services; 7, Agriculture, in relation to the establishment of some new public bodies (like the National Cadastre Office), subordinated to the central public administration or of some local responsibilities in the field of animal protection, land fund, etc.; $\mathbf{1 2}$, Statistics, 13, Social policy and employment of labour force, in relation to some specific bodies operating at national level of public administration; 14, Energy, in relation to the role of local public administration in energetic efficiency; 15, Industrial policy, in relation with the administrative barriers and business environment and training for public administration officials; 19, Telecommunications and IT, in relation to the digitalisation of the public administration services and e-government; $\mathbf{2 1}$, Regional policy and coordination of structural instruments, in relation to Nomenclature of Territorial Units for Statistics and public administration units as beneficiaries of the Programme ISPA Environment; 22, Protection of environment, in relation to the role of central and local public administration in protected areas, water and waste management, with the role of public administration in environmental law enforcement and completion of the sewerage and sewage infrastructure; $\mathbf{2 3}$, Health and consumers protection, regarding the collaboration of Consumer Protection Office with central and 
different for each candidate/member state (Bouckaert, Nakrošis, and Nemec $2011,10)$. Despite of this missing capability, "the reform of public administration in the candidate countries has become one of the main EU accession requirements since the EU Summit in Copenhagen in 1993 and Madrid in 1995" (Cardona 2009, 7), and EU refers to the national administrations as constituting the "European Administrative Space", namely one of "a common set of standards for action within public administration, which is defined by national law and enforced through relevant procedures and accountability mechanisms" (Cardona 2009, 7). ${ }^{1}$ Hence, although the candidate states had all the liberty ${ }^{2}$ concerning the means used to reform their public administrations, EU considered the public administrations of the new candidate states from three large perspectives: i./ to be able to accomplish the Criteria of Copenhagen, Madrid and Luxembourg, namely to have the "ability to take on the obligations of membership including adherence to the aims of political, economic and monetary union" in view of implementation of the Acquis Communautaire (European Parliament 1993; Cardona 2009, 3); ii./ structural and investment funds dedicated to economic development of EU's member states could be used as soon as possible by those who need them, and for this purpose, establishing regional structures able to use them was considered necessary; iii./ the role of

local public administration units; $\mathbf{2 4}$, Justice and internal affairs, with regards to fight against organised criminality; 28, Financial control, regarding local taxes, financial activities of public administration units (CLR 2015). The Chapter 30, Institutions, provided the obligation, for Romanian part, to improve the fight against corruption by different means: tests of integrity, public campaigns, direct phone line for complaints of corruption, trainings for public officials, adopting laws of decentralisation, salaries of public officials, establishment of Professionist Body of Prefects (Fuerea et al.).

${ }_{1}$ An indirect presence of EU, especially related to the integration process, could be found in the establishment of some supranational organisations that European Public Administration Network, The Network of Institutes of and Schools of Public Administration in Central and Eastern Europe.

${ }^{2}$ A liberty that was not all the time well managed and which rather disorientated some candidate states and involved, in the end, after accession, a supplementary monitoring period from the part of EU (Societatea Academică din România 2013, 34-37). 
public administration in good governance, namely in its relations with citizens, relations based on citizens' participation in decisional process, the respect of the laws, efficiency, transparency, professionalism and depoliticisation (Comisia Europeană 2015; Asociația Pro Democrația et al. 2007, 6; Șandru and Tripon 2007, 103-104) ${ }^{1}$.

Any of these issues could be analysed from different perspectives, but this is not the objective of this study, that has proposed to focus on regionalisation and decentralisation issues as a result (and condition) of the process of accession and of European integration of Romania (Klárik 2004, 76-77, passim; Balogh 2000, 1213; Bouckaert, Nakrošis, and Nemec 2011, 11) and representing the second dimension of the public administration reform.

Considering all these theoretical perspectives, the hypothesis of the present study is that the EU was the main engine for the post-communist reform of Romanian public administration, according to some areas of the Acquis Communautaire, conditioning these reforms with the objective of Romania's future accession. The study contains both a quantitative and qualitative analysis of the adopted juridical norms that directly supported the second dimension of Europeanisation, that related to the establishment of some new structures, at least theoretically more efficient in the use of the structural funds and, by consequence, very important for the general economic development of the Romanian society. The study is following two directions of research: a horizontal one, referring to the process of Europeanisation in pre-accesion and postaccession period, and a vertical one, referring to the same process from bottomup and from up to down. The conclusions highlight the main results of the study and restate the change-agent role of EU in the case of Romanian public administration. Hence, the aim of the study is to put into evidence in what extent the EU acted as an agent of change in an area for which the acquis is weak represented and its pressures boosted the dynamic of reforms for a given period of time.

${ }^{1}$ An analysis on the official perspective the European Commission has developed on governance and good governance was realised in Ion (2013, 93-98). 


\section{FROM PRE-ACCESSION TO INTEGRATION: LEGISLATIVE AND ORGANISATIONAL APPROACHES}

\subsection{Pre-accession period}

Although it is not really difficult to largely define the pre-accession period, if we consider positions of some researchers (see the note 3) it is possible to split it in almost two chronological stages: one which starts on 22 June 1995, when Romania launched its EU membership application and ends in December 1999, when the European Council from Helsinki decided to accept Romania's demand, and one developed in the framework of negotiations process, started on 15 February 2000 and finished in December 2004, and concluded with the Treaty of accession (25 April 2005) (European Commission 2015; European Council 1999). The 2005-2007 period may be considered as one of completion, related to the preaccession but also with one foot on the boat of integration, and for this reason I considered it somewhat separately.

Therefore, the pre-accession period, with its takeover of Community Acquis, was very important for Romanian public administration reform, for its modernisation, Europeanisation, according to the demands of EU and, in a given extent, to the demands of the economic and social domestic environments. All the above-mentioned directions of interest of EU on the public administration of the candidate states were implicitly included in the chapters of negotiations and materialised, at the end of the negotiation process, in some new judicial norms and some new specialised institutions, subordinated to some of the central bodies of public administration. Taking into account the three dimensions (presented in the introduction) of EU's interest in the public administration of the candidate states, it is possible to reveal three main dimensions of the public administration reform (adopted in the pre-accession period and continued in the period of integration): first is related to its relations with citizens and economic environment; the second concerns the relations between the different levels of the administrative system (local, regional and central), and the last regards the functional capacity of the administrative system (the law of the prefect; the law of public finance and others). It is difficult to establish a hierarchy between the 
three levels of reform, each one being important both by itself and in its interdependences with the other two. These dimensions of reform considered by EU could be retrieved in the directions of public administration reform established by Romanian strategy of reform, and were: strategical (redefining the role of the State in the administrative act), legal (reducing legal confusion by adopting framework laws), organisational (simplification of procedures) and cultural (changing values and mode of action ${ }^{1}$ of elected representatives and local officials ${ }^{2}$.

1 As for example the strategies related to the reform and digitalisation of public administration, adopted in 2001. (Strategia Guvernului 2015, 6-7; Guvernul României. Ministerul Administrației Publice 2015). Hudrea (2014) and Moldovan and Macarie (2016) realised two important approaches of organisational culture and applied their researches on some aspects of organisational culture in Romanian public administration, such as typology of organisational culture, the matter of collectivism, the use of working time, meritocracy, power distance and so one. For this study I considered the organisational processes and the behavioural patterns between the members of the public administration and with its beneficiaries as being very important to be changed in the post-communist period, and I analysed the adopted laws that deserved this approach. Hintea and Mora $(2005,85)$ consider that public organisations "must be able to stimulate the involvement of their members on the basis of understanding values and principles operating in the public domain." Understood from this perspective, the organisational culture of must be "part of the reform", as Șandru and Tripon $(2007,102)$ highlighted too.

2 We could add to the citizens in this approach of culture. For Ágh (2013, 741-742) citizens and their active participation in decisional process are essential in the process of Europeanisation, of reaching the third stage of development of political system, that based on the so "sophisticated" governance, which is, in fact, asked to be reached in the process of European integration in order to recover the "historical delay" between the old and the new members of EU and to provide "the institutional reintegration of the public administration to the public life" (Ágh 2013, 746)). Is also Ágh (2010, 7sqq) who highlighted the increased necessity to reform the EU members' public administrations (especially in terms of performance and effectiveness, the main characteristics of the new public management) in order to better cope with challenges of the international crisis, and pointed out the role allotted to regions by Lisbon Strategy in what concerns both the competitiveness and social cohesion. 
Hundreds of legal norms related to the public administration reform were adopted in the pre-accession period, and a qualitative survey of their content could disclose the main directions they focused (strategical, legal, organisational or cultural). The table below (although not exhaustive) attempts to expose the main legal rules focused on the public administration reform with their focus on the second dimension of reform, that concerning the relations between the different levels of the administrative system.

\begin{tabular}{|c|c|c|}
\hline \multicolumn{3}{|c|}{ Legislation supporting the reform of Romanian public administration } \\
\hline & Legal norm & Direction of reform \\
\hline \multirow{6}{*}{$\begin{array}{l}8 \\
\text { \% } \\
\text { 'े } \\
8\end{array}$} & $\begin{array}{l}\text { Law no. 199/1997 ratifying the European Charter of } \\
\text { Local Self-Government }\end{array}$ & Strategical \\
\hline & $\begin{array}{l}\text { Law no. 151/15 July } 1998 \text { on regional development in } \\
\text { Romania }\end{array}$ & Organisational \\
\hline & $\begin{array}{l}\text { Law } 189 / 1998 \text { on local public finances (amended by } \\
\text { Law } 86 / 1999 \text { ) }\end{array}$ & Organisational \\
\hline & $\begin{array}{l}\text { Law 213/17 N ovember 1998,on public property and } \\
\text { its legal status }\end{array}$ & Organisational \\
\hline & $\begin{array}{llll}\text { Law } 115 / 1999 \text { on ministerial responsibility } \\
\text { (republished in 2007) }\end{array}$ & Organisational \\
\hline & Law 188/1999 on civil service regulations & Organisational \\
\hline & $\begin{array}{l}\text { Law } 5 / 2000 \text { on the approval of the } \mathrm{N} \text { ational } \\
\text { Landscaping Plan - Section III - protected areas }\end{array}$ & Organisational \\
\hline & Law $326 / 2001$, the law of municipal public services & $\begin{array}{l}\text { Organisational, } \\
\text { Cultural }\end{array}$ \\
\hline & $\begin{array}{l}\text { Law } 90 / 2001 \text { on the organisation and functioning of } \\
\text { the Romanian Government and ministries }\end{array}$ & Organisational \\
\hline & $\begin{array}{l}\text { Decision 299/2001 approving the Regulation of } \\
\text { reorganisation and functioning of the } \mathrm{N} \text { ational } \\
\text { A gency of Civil Servants }\end{array}$ & Organisational \\
\hline & $\begin{array}{l}\text { Decision } 336 / 2001 \text {, establishing the } N \text { ational } \\
\text { Committee for Coordination of Rural Development } \\
\text { Project }\end{array}$ & Organisational \\
\hline
\end{tabular}

${ }^{1}$ For an analysis of the problems of reform in this period see Hințea (1999). 


\begin{tabular}{|c|c|}
\hline $\begin{array}{l}\text { Law } 10 / 2001 \text {, on the legal regime of some buildings } \\
\text { taken abusively during } 6 \mathrm{M} \text { arch } 1945 \text { - D ecember } 22 \text {, } \\
1989\end{array}$ & Cultural \\
\hline $\begin{array}{l}\text { Decision no. 951/27 September } 2001 \text { on the } \\
\text { establishment of the Government Council for } \\
\text { monitoring public administration reform }\end{array}$ & Organisational \\
\hline $\begin{array}{l}\text { Decision no. 1006/4 O ctober 2001, approving the } \\
\text { Government Strategy on accelerating public } \\
\text { administration reform }\end{array}$ & Strategical \\
\hline $\begin{array}{l}\text { Decision no. } 1007 / 2001 \text { approving the Government } \\
\text { Strategy regarding the public administration }\end{array}$ & Strategical \\
\hline Law no. $544 / 2001$ on free access to public information & Cultural \\
\hline $\begin{array}{l}\text { Law 215/2001, of public administration (completed by } \\
\text { Emergency Government no.74 / } 2001 \text { and by laws } \\
\text { 216/2002; 141/2004; 286/2006; } 131 / 200835,50,323 \\
\text { and 375/2009,59/2010) }\end{array}$ & Organisational \\
\hline $\begin{array}{l}\text { Ordinance no. } 81 / 2001 \text { on the establishment and } \\
\text { organization of the } \mathrm{N} \text { ational Institute of } \\
\text { Administration by Law } 329 / 2009 \text { repealed and } \\
\text { replaced by GD 1000/2006 }\end{array}$ & Strategical \\
\hline $\begin{array}{l}\text { O rdinance no. 21/2002 on the management of urban } \\
\text { and rural areas - approved by Law no. 515/2002 }\end{array}$ & Strategical \\
\hline $\begin{array}{l}\text { Ordinance no. } 24 / 2002 \text { regarding collection by } \\
\text { electronic means of local taxes - approved by Law no. } \\
522 / 2002\end{array}$ & $\begin{array}{l}\text { Organisational, } \\
\text { Cultural }\end{array}$ \\
\hline $\begin{array}{l}\text { O rdinance no. } 35 / 2002 \text { approving the Regulation for } \\
\text { organizing and functioning of local councils }\end{array}$ & Organisational \\
\hline $\begin{array}{l}\text { Emergency Ordinance no. } 5 / 2002 \text { on imposing } \\
\text { restrictions for local elected officials and civil servants }\end{array}$ & $\begin{array}{c}\text { Organisational, } \\
\text { Cultural }\end{array}$ \\
\hline $\begin{array}{l}\text { Government Decision 209/2002, approving the action } \\
\text { plan for removing administrative barriers in business }\end{array}$ & Cultural \\
\hline $\begin{array}{l}\text { Ordinance no. } 8 / 23 \text { October 2002, to ratify the } \\
\text { Financing M emorandum between the Romanian } \\
\text { Government and the European Commission on } \\
\text { horizontal program to prepare candidate countries for } \\
\text { Extended Decentralisation (EDIS) in the management } \\
\text { of pre-accession funds in Romania }\end{array}$ & Strategical \\
\hline Law $500 / 2002$, on public finances & Organisational \\
\hline
\end{tabular}




\begin{tabular}{|c|c|}
\hline Law $672 / 2002$, on public internal audit & Organisational \\
\hline $\begin{array}{l}\text { Decision no. } 1.555 \text { / } 2002 \text { on the designation of } \\
\text { institutions and bodies responsible for the } \\
\text { coordination, implementation and management of EU } \\
\text { financial assistance through structural instruments }\end{array}$ & \\
\hline $\begin{array}{l}\text { Ordinance no. } 27 / 2003 \text {, amending and supplementing } \\
\text { Law no. 151/1998 on regional development in } \\
\text { Romania }\end{array}$ & Organisational \\
\hline $\begin{array}{l}\text { Law no. 256/10 June } 2003 \text {, approving the } \\
\text { Government O rdinance no. } 27 / 2003 \text { amending and } \\
\text { supplementing the Law no. } 151 / 1998 \text { on regional } \\
\text { development in Romania }\end{array}$ & Organisational \\
\hline $\begin{array}{l}\text { Law } 96 / 2003 \text {, approving Government Ordinance no. } \\
53 / 2002 \text { Framework on the Statute of the } \\
\text { administrativeterritorial unit }\end{array}$ & Legal \\
\hline $\begin{array}{l}\text { Law no. 161/19 A pril 2003, on measures to ensure } \\
\text { transparency in exercising public dignities, public } \\
\text { functions and in the business environment, } \\
\text { preventing and sanctioning corruption }\end{array}$ & Cultural \\
\hline $\begin{array}{l}\text { Law no. } 340 / 12 \text { July } 2004 \text {, on the institution of the } \\
\text { prefect }\end{array}$ & Organisational \\
\hline $\begin{array}{l}\text { Emergency Ordinance no. 56/2004 on the } \\
\text { establishment of the special status of civil servant } \\
\text { called public manager }\end{array}$ & $\begin{array}{l}\text { Organisational, } \\
\text { Cultural }\end{array}$ \\
\hline $\begin{array}{l}\text { Law no. } 7 / 18.02 .2004 \text {, Code of conduct for civil } \\
\text { servants }\end{array}$ & Cultural \\
\hline $\begin{array}{l}\text { Decision no. } 1.083 \text { / } 2004 \text { on the organisation and } \\
\text { functioning of the N ational Institute of } \\
\text { Administration and regional training centres for local } \\
\text { government }\end{array}$ & \\
\hline Law 315/2004, on regional development in Romania & Organisational \\
\hline $\begin{array}{l}\text { Decision no. } 2.001 \text { / } 2004 \text { for the amendment of Art. } \\
18 \text { of Government Decision no. } 497 / 2004 \text { establishing } \\
\text { the institutional framework for coordination, } \\
\text { implementation and management of structural } \\
\text { instruments }\end{array}$ & Organisational \\
\hline $\begin{array}{llllll}\begin{array}{l}\text { Framew ork Law } \\
\text { decentralisation }\end{array} & \text { no. } & 339 / 12 & \text { July } & 2004 & \text { on } \\
\end{array}$ & $\begin{array}{c}\text { Legal, } \\
\text { Organisational }\end{array}$ \\
\hline
\end{tabular}




\begin{tabular}{|c|c|c|}
\hline & $\begin{array}{l}\text { Emergency Ordinance no.111 / } 2004 \text { amending and } \\
\text { supplementing Law no. 315/2004 on regional } \\
\text { development in Romania }\end{array}$ & \\
\hline & $\begin{array}{l}\text { Decision no. } 497 / 2004 \text {, establishing the institutional } \\
\text { framework for coordination, implementation and } \\
\text { management of structural instruments }\end{array}$ & Organisational \\
\hline & $\begin{array}{l}\text { Law 554/2004, the administrative jurisdiction } \\
\text { (amended in } 2007 \text { and 2008) }\end{array}$ & Organisational \\
\hline & $\begin{array}{l}\text { Decision no. 699/2004 approving and updating } \\
\text { government strategy on accelerating public } \\
\text { administration reform for 2004-2006 }\end{array}$ & Strategical \\
\hline & $\begin{array}{l}\text { Decision 1256/2004 approving the Regulation for } \\
\text { organizing and functioning of regional development } \\
\text { councils }\end{array}$ & Organisational \\
\hline & $\begin{array}{l}\text { Decision N o. 772/14 July } 2005 \text { to approve the } \\
\text { organisation and functioning of the } \mathrm{N} \text { ational Council } \\
\text { for Regional Development }\end{array}$ & Organisational \\
\hline & Framew ork Law no. 195/2006 for decentralisation & $\begin{array}{c}\text { Legal, } \\
\text { Organisational }\end{array}$ \\
\hline & Law no. 273/2006 on Local Public Finance & Organisational \\
\hline 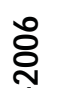 & $\begin{array}{l}\text { Law no. } 286 / 2006 \text { amending and supplementing the } \\
\text { Law no. } 215 / 2001 \text {, on Local Public A dministration }\end{array}$ & Organisational \\
\hline ర్d & $\begin{array}{l}\text { Law no. 181/2006 the approval of O U G no. 179/2005 } \\
\text { amending and supplementing Law no. 340/2004 } \\
\text { regarding the institution of the Prefect }\end{array}$ & Organisational \\
\hline & $\begin{array}{l}\text { Decision no. } 1000 / 2006 \text { on the organization and } \\
\text { functioning of the } \mathrm{N} \text { ational A gency of Civil Servants }\end{array}$ & Organisational \\
\hline & $\begin{array}{l}\text { Emergency O rdinance N } 0.1 \text { / } 2006 \text { on measures to } \\
\text { strengthen administrative capacity for the integration } \\
\text { of R omania into the European U nion }\end{array}$ & Organisational \\
\hline
\end{tabular}

Source: realised by author using information from Indaco LegeStart (2015) and CLR (2015).

The information presented in the table above reveals that the interest of Romanian government for the reorganisation of the public administration was enough important in the period of negotiating the EU's accessing process. As it is possible to observe following this qualitative survey of the main legal norms, the 
perspective of the future integration to EU imposed to Romania some new principles related to the organisation, not only to functionality ${ }^{1}$ of the public administration, as the principle of subsidiarity applied in the process of decentralisation and regionalisation, all with a very well-known double aim: for a closer relation between citizens and decision-makers and to solve the issue of distribution of European structural funds. The organisational approach represented the core of public administration reform in the pre-accession period, and this situation has prompted many complaints from a part of the public opinion, considering the adopted measures as insufficient for a future member state of EU. Assuming and applying the principle of subsidiarity and realising the decentralisation and regionalisation process were some perspectives also approached by some small groups of opinion leaders and some civil organisations ${ }^{2}$ in some key moments and for a short-enough period of time, but without influencing the decision-makers. The visible legislative relaxation ${ }^{3}$ of the

${ }^{1}$ As a result of the new legal rules related to the reform of public administration, some organisations focused on the assessment of the efficiency of this field, were established, although there is not so much data about the results of this assessment process. So, Association of the Economic Directors of County Councils of Romania, by a European funded project, tried "to define, to formulate and to interpret a set of economic and financial indicators for evaluating the effectiveness of local government management, the analysis of performance, and to track how the objectives of the reform are implemented and the decentralisation process is developed." (PNAP 2005a)

2 It is possible to mention especially the following: Proclamation of Timişoara, in 1989; the group "Provincia", 1998-2001 or the members of the group "Liga ProEuropa", 1995-2007; occasional articles in the weekly Revista 22 or in different newspapers. More information about the approaches of the opinion leaders in: Dogot (2006, 103110; Revista 22 2015). The debates organised by opinion leaders were usually related to some events dwell with political discussions or project of law related to the process of regionalisation. Hence, with the exception of some specialists who focus systematically, by their researches, on this process, in the pre-accession period the issue of regionalisation does not really represent a subject matter for public opinion.

${ }^{3}$ Nonetheless, considering the amount of adopted legislative documents, Șandru and Tripon $(2007,103)$ appreciated the public administration as being more dynamic (299 new laws) than health (207) and education system (115 new laws). 
two years before the moment of integration to EU is a proof that Romanian authorities did not assume, in their entirety and with full conviction, those principles and the very concept of public administration reform. It is an incipient phase in this sense ${ }^{1}$, but at the same time it begins the period when Romania will do it not only because of EU pressures, but because of the fact that some rules or principles are implemented with difficulty ${ }^{2}$, the challenges that local public administration are more and more important and various, and so EU will be accompanied in its requirements by some local pressures for reform and modernisation.

As regarding the decentralisation, it represented an objective of all the governments and prime-ministers of the period of pre-accession and integration, and it was intended to be finished until 2008, when the transfer both of attributions and resources had to be realised. With this purpose was adopted the Framework Law 195/2006 on decentralisation (PNAP 2005b), and starting with the same year the government began the restructuration of the central public authorities, under the survey of the Central Unit for Public Administration Reform (established in 2002) (Profiroiu 2002,13-23), but this process has not been without problems. The local authorities had not the experience to manage the public services (schools, hospitals, cultural institutions, sports hall, public safety, social assistance, institutions related to environment and agriculture, asset management), and initially tried to resist accepting new responsibilities, particularly that they were distributed without the necessary funds to achieve them (PNAP 2010b).

From a cu cultural point of view, in 2008, Liviu Radu, the Secretary of the State charged with administration reform in the Ministry of Interior and Administrative Reform, considered that despite of the various training programmes for the public officials, it existed yet, amongst them, "complacency

${ }^{1}$ For example, they were established the principles and the fields of decentralisation and local administrative autonomy but outside of any fiscal decentralisation and autonomy too.

${ }^{2}$ As for example the principle of transparency and predictability of funds allocation, which was not entirely and all the time respected. 
or lack of desire to make reform", lack of planning, lack of a culture of evaluation and of practice of impact analysis (especially at local level). (PNAP 2008) Since 2008 were launched numerous debates related to the financial decentralisation and were adopted new legal norms related to local finances, procurements, deconcentration, healthcare, education, decentralisation of competitions for leading positions. In 2011 the process seems to have become more balanced, though is yet unfinished. The change of government in 2012 and the failure of the process of regionalisation refocused attention of decision-makers on the unachieved objectives of decentralisation and elaborated a new law of decentralisation, but a new failure will be registered when Romanian Constitutional Court considered it as unconstitutional. (Andrei 2013; PNAP 2014a) The presidential elections of the end of 2014 diverted attention of decision-makers from the matter of decentralisation (PNAP 2014d), and so the problem of decentralisation could be found on the agenda of the newly installed government, that of Dacian Cioloș (PNAP 2015a).

\section{THE POST-ACCESSION PERIOD AND THE MATTER OF REFORM : APPROACHES FROM UP TO DOWN}

In order to compare the pre-accession and post-accession periods from the perspective of initiated and realised reforms I used the legislative database Indaco LegeStart and the information retrieved on the national public administration portal, that are the official sources of information for the status of reform of the Romanian public administration. In addition to these sources could be analysed the political positions and programmes related to public administration reform, but I considered the approaches of some other authors (Búkfeyes-Rákossy 2015; Hințea and Neamțu 2014/2015; Nakrošis and Bankauskaitè-Grigaliūnienė 2014; Ágh 2013; Ágh 2010) as being sufficient in arguing the legislative evidences presented bellow.

Although still monitored, in post-accession period Romania seems even more chaotic in terms of the process of reform of public administration. Hence, after its 
accession to EU, the $1^{\text {st }}$ January 2007, Romania stagnated ${ }^{1}$ the process of regionalisation in spite of some less developed and never accomplished political initiatives which rose especially in the period 2011-2013, under the pressure of the new budgetary period of EU, 2014-2020, and of the new rules on financing (PNAP 2013c; 2011a; Hințea and Neamțu 2014/2015, 92, Săgeată 2012). It is possible to assert that, for the post-accession period, the extended role of changeagent from the EU to the Europeanised structures, in our case the public administration, is not (yet) deeply and in a homogenous manner achieved by the administrative units. Different studies show that the level of real compliance with the values and principles of the agent of change modified in the postaccession period for all the states of the Central and Eastern Europe, under the influence of various factors: the objective of accession was reached; before the Lisbon Treaty, the missing capabilities of the EU related to national public administration, and after the failure to apply the new adopted norms and sanctions; political and ideological changes at national level; conservatism and even opposition toward the institutional reform; institutional and cultural differences (Nakrošis and Bankauskaitè-Grigaliūnienè 2014, 6; Bouckaert, Nakrošis, and Nemec 2011; Elbasani 2009, 5). Nonetheless, relevant legal rules related to the cultural aspects were adopted and they started to produces their effects, although the pressure of citizens for this type of changes is not the same for all the units of public administration, and so changes are different for urban and rural areas, as for different regions. As regards the deepening of the organisational reform, this faced both an up to down (rather less) dynamic, and an opposite one, from down to up, but from a different perspective. The first one, from up to down, refers to the essays of the central public administration, by its decision makers, to continue the process of decentralisation and regionalisation, but if decentralisation improved in some aspects, the regionalisation remained unchanged, although in 2014 the Chairman of the Committee for Public

1 Ágh $(2013,743)$ considers this phenomenon of "reform fatigue” as a natural one, in the context of the hard works developed in the candidate states in order to access the EU and the "cumulative" and „stormy transformations" resulted (in a short time) from these efforts. See too Goetz $(2001,1041)$. 
Administration and Spatial Planning of the Chamber of Deputies, Victor Paul Dobre, stated that the "Romanian government has reached its limits and requires a major administrative reform" (PNAP 2015c).

\begin{tabular}{|c|c|c|}
\hline \multicolumn{3}{|c|}{ Legislation supporting the reform of Romanian public administration ${ }^{1}$} \\
\hline \multirow{3}{*}{$\begin{array}{l}\frac{1}{\$} \\
\frac{1}{2} \\
\frac{1}{2} \\
\delta \\
\delta\end{array}$} & Legal norm & $\begin{array}{l}\text { Direction of } \\
\text { reform }\end{array}$ \\
\hline & $\begin{array}{l}\text { Ordinance no. 139/2008 approving the rules for the } \\
\text { application of the Framework Law for } \\
\text { decentralization no. 195/2006 }\end{array}$ & Strategical \\
\hline & $\begin{array}{l}\text { Law no. } 329 / 2009 \text { on the reorganization of public } \\
\text { authorities and institutions, rationalisation of public } \\
\text { expenditure, business support and compliance } \\
\text { framework agreements with the European } \\
\text { Commission and the International M onetary Fund }\end{array}$ & Organisational \\
\hline 2013 & $\begin{array}{l}\text { Decision to amend the Annex of Decision no. } \\
137 / 2013 \text { of Prime minister, on the establishment of } \\
\text { the Inter-ministerial Technical Committee for } \\
\text { regionalization-decentralization }\end{array}$ & Organisational \\
\hline
\end{tabular}

Source: realised by author using information from Indaco LegeStart (2015) and CLR (2015).

A qualitative survey of the references to the regionalisation on the National Portal of Public Administration ${ }^{2}$ could reveal the new dimension of public

${ }^{1}$ To these legal norms is necessary to add the specific organisational rules adopted in the process of decentralisation, but because of their great number we prefer not to enumerate them here.

${ }^{2}$ On the National Portal of Public Administration there are more than 300 articles and links to articles related to the opinions of political leaders and local elected officials on the matter of regionalisation. A qualitative survey on these revealed how much the Romanian officials changed their approach with regards to the necessity of 
administration reform from the perspective of regionalisation. As an example, Vasile Dâncu, one of the leading specialists in the issue of regionalisation and an influential member of one of the political parties who tried constantly, during the pre-accession period, to oppose this process, believes that regionalisation "must be conducted with rationality and targeted primarily on modernising administration", a modernisation consisting in a bigger activism of local administration, possible by another type of education of the public officials, a simplification of bureaucracy ${ }^{1}$, all these being a source, in the end (after one-two decades), of a bigger social cohesion and for fewer gaps between the centre and peripheral regions of Romania. (PNAP 2013j) These ideas were completely impossible for the largest part of politicians of the pre-accession period, and the key characters and the quality of Romanian political class did not change dramatically this time. However, despite the re-launch of debates on regionalisation and of larger public support (PNAP 2013i) than in pre-accession period, some missing elements in achieving this process were, beside some legal aspects (the necessity to modify the Constitution ${ }^{2}$ and some laws), the misunderstandings both with political opposition (in Parliament and at local level, in the public administration units) and the political will. The intended and frequently invoked referendum regarding the modification of Constitution never held, notwithstanding an assessment of the public support for regionalisation, which revealed that Romanians were now largely favourable to this process; the poll opinion revealed that citizens generally supported decentralisation and even

regionalisation and decentralisation, although some conservative voices still persist (PNAP 2015).

1 "Bureaucracy was seen as one of the fundamental explanations for the current crisis of the Romanian administration" (Goudenhooft 2009, 76), and the highly bureaucratised institutions, as the public administration is, are the most resistant to the changes, whatever these changes are asked by citizens (bottom up) of other institutions, even superior institutions (up to down) (Tripon and Ghiolțan 1999; Hințea and Șandor 2000, 29-30 Filip and Onofrei 2000, 115).

${ }^{2}$ Already modified in 2003, so in the period of negotiations, but without considering, at the time, the problem of regionalisation, but, on the contrary, trying to avoid it constantly. 
regionalisation. Endless discussions on regionalisation based on local fears and/or prides ${ }^{1}$, the lack of knowledge and understanding of the advantages of regionalisation in financing the local project, the difficulties in establishing the distribution of financial resources and of attributions, the different plans of politicians and of specialists (PNAP 2006), with the certainty that EU funds will not be lost if the new regionalisation process were not to be achieved, dramatically shortened the time devoted to the regionalization process, leading to its possible delay for 2022 (PNAP 2013d, e). Hence, though not because of it, the EU has not acted as an agent of change in the regionalisation during Romania's integration process. The Euro-parliamentary and presidential elections of 2014 completely removed the attention of decision makers from the matter of regionalisation, and 2015 changed nothing, despite of some expressed intentions in this sense (PNAP 2014b, c). According to the law adopted in 2004, Romanian regions of development "are not administrative units and have no legal personality" (Legea 315/2004). Therefore, they cannot benefit directly from the European funds, and the local autonomy is dramatically limited. After more than ten years of regional experience the specialists considered that a reform of the regional framework would be necessary, especially that in the actual formula authorities failed to obtain the expected effects (SAR 2013, 34-37). However, for the moment, this reform is not on the public agenda.

Nonetheless, despite the failure of renewing the regionalisation process, in February 2013 the Consultative Council for Regionalisation (CONREG), composed of specialists of some universities, local administration officials and NGO's representatives working groups was established and the role of which was "to ensure the necessary expertise in outlining the profile of the future regions" (PNAP 2013a), and the Inter-ministerial Technical Committee for Regionalisation-Decentralisation (CTIRD), whose role has to be "to draw up draft legislation to transfer powers to sectorial categories of administrative units" (CTIRD 2015). In May 2013 the Ministry of Regional Development and Public Administration established its own sub-section dedicated to the matter of

${ }^{1}$ A synthesis of these debates was realised by Zombor Búkfeyes-Rákossy (2015). 
decentralisation-regionalisation (PNAP 2013f), but the page of the Strategy for the Regional Development of Romania, 2014-2020 is yet under construction (the website seems to have not been updated since 2013) (MDRAP 2015a, b). Nevertheless, the government that took office in 19 November 2015 discussed the reform of administration during its first meeting (Ionescu 2015).

\section{THE POST-ACCESSION PERIOD AND THE MATTER OF REFORM : APPROACHES FROM BOTTOM UP}

The economic growth of the period before 2007-2008, the opportunities offered by EU funds and by globalisation, beside certain changes related to the quality of human resource in some important local public administrations (like Cluj, Oradea, Iași) involved a change of the centre of pressure for reform from the central government to local administration units. The modernisation provoked by the local public administration is not so spectacular and so deeply analysed like the changes caused by the EU integration process ${ }^{1}$, and concerns especially the functional dimension of local public administration. Any legal rule adopted following a need of the local units of public administration is directly related (by title of content) to the matter of reform, but most of them were the basis of important changes in terms of some new attributions allotted to the local administration, new resources. So, it is possible to assert that EU was also an indirect agent of change 2 : offering some opportunities to the local levels of public administration it determined new needs and so official requests addressed to the central government. At a formal level, the influence from down to up was

${ }^{1}$ In what concerns the concept of integration, I prefer the approcah of Ágh $(2013,742)$, who consider it as the "further adjustments for the New Member States".

${ }^{2}$ For different kinds of direct and indirect effects EU can induce at national level on polity, politics and policy items, see Ion (2015, 1-17). The study underlines the prominence of indirect EU effects on areas related to polity or politics items, in comparison with the policies subjects where EU has increased capabilities to determine change. 
possible by the different forms of association of the local administrative units, as for example: Association of Towns from Romania; Association of Municipalities from Romania; Federation of Local Authorities from Romania (the latter includes the first two associations and Association of Communes from Romania). Through their representatives, according to their statutes and the legal framework of Romania, the associations, with their proposals, could be part of the central legislative process.

Confronting the bureaucracy of the central government related to the European funds, the local authorities asked for more attributions in direct access of this type of funds, as they asked for more influence of local authorities in establishing the content of the new laws. (Autoritățile locale vor libertate 2009; PNAP 2010a, 2013h, 2013b) Exception of information about the different requests of associations of local authorities to be heard in decisional process and the numerous references of central decision-makers related to the needs of local administrative units, some data or information related to the real influence of the associations of the local administrative units over the legislative decisions were not found. However, despite these difficulties in establishing a direct formal agent-change relation between the local administrative units and the central public authorities, their interaction represent a basis for the next changes in terms of adopted legislation ${ }^{1}$, allotted funds, democratisation of the basis of cooperation, and, in the end, of decentralisation and regionalisation not only by the allocation of competencies from up to down, but by request of major competencies from down to up (as for example the establishment of regions with legal personality and with some limited legislative attributions).

One of the most important directions of reform supported by the local administration concerns the metropolisation (PNAP 2005c) ${ }^{2}$. Although it is also a process started from up to down with the purpose to offer to cities and

${ }^{1}$ During a meeting with the government initiated in December 2015 it was established to develop periodical meetings with the Association of Towns from Romania, in order to discuss the proposal or demands of municipalities with the different responsible ministries. (Portalul Național de Administrație Publică 2015b)

${ }^{2}$ See more about metropolisation in Romania in: Dogot (2013). 
municipalities (and to the communes around them) the possibility to attract and use the Structural Funds for 2007-2013 financial cycle, the legal framework was rather restrictive. The initial legislative framework was not proper in achieving the economic objectives of metropolitan areas (Dogot 2013, 86-87; Hințea and Neamțu 2014/2015, 80-81, 90-91), and in spite of almost immediate pressures from the part of metropolitan areas, the central level delayed in improving it. The most telling example is the project of law of Bucharest Metropolitan Area elaborated in 2003 and which was never adopted. (Garaiman 2013; Legea Zonei Metropolitane București) However, the metropolitan areas act as an agentchange by their important economic role for municipalities and the rural areas around. The expectancies related to the metropolitan areas are very high in Romania, in a great extent because they are yet perceived as producers of local welfare, by opposition to the central - far away and corrupted - government. So, they could be a positive counterexample, the image of a given type of reform under the quiet pressure of which the political (local or central) actors have to reshape their public performance (and so to realise the reform of the public administration too).

\section{CONCLUDING REMARKS}

In the end of the study I may assert that present research confirmed the hypothesis. The quantitative and qualitative data revealed the different dynamic of the Romanian public administration reform for the pre-accession and the postaccession periods. This phenomenon is not a particular one, the studies realised (Hințea and Neamțu 2014/2015; Nakrošis and Bankauskaitè-Grigaliūnienė 2014; Ágh 2013; Bouckaert, Nakrošis, and Nemec 2011, 14-15; Elbasani 2009) for some other post-communist states show that the situation is similar (with some positive and negative differences, it's obvious) for each of these states. For the post-accession period, when Romania has slowed the process of reform in the field of public administration, and so it is possible to consider that the State and its authorities perceived the pre-accession process as a factor of structural closure with the EU, while for the post-accession period, given to the fact that 
administration is "only" a competence of support, cast-off Romania from the 'stress' of reforms in a field that is related to the State, not to the EU competencies. Hence, in this moment it is fair to state that EU represented an agent of change as long as it conditioned the accession of candidate states, though the acquis does not represented an advantageous instrument for the EU in the negotiation process. Once accessed, the new members diminished their interest in organisational reform of the public administration and slowed dramatically the rhythm of changes.

Even if the EU is not directly involved in the continuation of the public administration reforms, it does not completely disappeared from the process of reform. Indirectly, supporting at least partially the financial costs of some supranational organisations and instruments ${ }^{1}$ directly involved in the matter of European public administration (structural and social funds, different programmes related to public administration modernisation, regional policies) to increase the administrative capacity of the new (and old) MS in their efforts to met with the new challenges of integration, on the one side, and of different external factors (as for example the economic globalisation), on the other side.

Albeit they are not directly related to the European system, it is obvious that national public administrations have an important, if not a decisive role, in putting into practice the Community Acquis, in achieving an EU closer to the citizens, in being the 'visible hand' of EU at the lowest possible level. Although from a distance and through the central state bodies, EU was accepted and

${ }^{1}$ As for example the institutions of research in the field of public administration or academic individual research in the field, as the agencies and non-governmental actors that are involved in analysing or supporting the reforms of the public administrations from the MS (two very important examples: European Institute of Public Administration, with its Common Assessment Framework; European Association for Public Administration Accreditation, with a very important role in providing the quality of the training institutes in the field of public administration); European Public Administration Network, an informal network established in the framework of DGs related to public administration, and supporting the cooperation between the public administrations of the MS (EIPA 2017; EAPAA 2017; EUPAN 2017). 
worked as an agent-change for any element of this relation: central public administration, local units of public administration, and, the final beneficiaries, the citizens (for any of these levels, the EU represented an sought catalyst of change, legitimising both the actions and the expectations for action of each of these levels). In their turn, all parts are acting as an external factor for the others, requiring something from each other (becoming an agent-change for the other(s)), and each of them did it on behalf of the EU. This is giving to the principle of subsidiarity ${ }^{1}$, whose application makes either party fail to be selfsufficient $^{2}$. A longitudinal analysis of decentralisation and regionalisation issues revealed this state of affairs, although the effects in Romanian public administration are not yet so significant in depth at any level. Nevertheless, the beginnings of change are already obvious for all the levels (citizens, local and central administration units), despite the low level of decisional maturity of any of these levels.

EU acted as an agent of change up to a certain level, the application of the principles and rules of the reform depending both on the quality of the human resources from the public administration units and on the level of interest of citizens to participate in public decision process. Despite of the great interest of EU in reforming the national administrations, for this case its famous conditionalism could be considered as incomplete as long as EU does not have all the tools of reform in its hands. In the lack of a complete conditionalism the process of Europeanisation is not imposed, but assumed by its various actors who are at the same time the agents and the beneficiaries of changes, and this situation also reduces the role of agent-change of EU. I did not focus on any qualitative variables (social and political backgrounds, political ideologies of domestic actors of regionalisation) in order to demonstrate these conclusions, for this I consider necessary a transversal study, analysing both the programmes

1 "Increasing the role of the regions and of their responsibilities on the basis of the principle of subsidiarity, turns them into carriers of democracy and in major elements of social and political development." (M iclăuș and Horea 2000, 82).

${ }^{2}$ However, it is difficult to say that, after the communist period, we arrived to think and to act according to the principle of subsidiarity. 
dedicated to public administration and to the citizens in their relations with public administration, and the eventual ideological influence on the process of reform (at least for some given periods). It depends by the political and social will of beneficiaries to assume the changes proposed by EU, but first of all by their capacity to understand the long-term consequences of their choices for the society. Another qualitative factor that have to be analysed in order to understand the capacity of Romanian society and political groups to assume the process of reform (and so of Europeanisation) of public administration is that of the common good, a concept that is difficult to say that it is specific for the former communist countries, which communism has learned to detest everything that is common.

The process of Romanian public administration reform is far away to be accomplished, but in the same time the public administration (despite of many internal specificities) is far away from its initial characteristics. Daily realities demonstrate that it is not yet efficient, de-bureaucratised, professionalised and, especially, depoliticised, but for some of its units differences from the beginning of the nineties are really important.

\section{REFERENCES}

- “ “Aderarea României la Consiliul Europei." 2015. [Romania's accession to the Council of Europe]. Accessed October 23. http:/ / coe.mae.ro/node/1252.

- Ágh, Attila. 2013. "Europeanization of Public Administration in Eastern and Central Europe: The Challenge of Democracy and Good Governance." Croatian and Comparative Public A dministration 13: 739-762. Accessed October 10, 2017.

https:/ / pdfs.semanticscholar.org/d324/abc6094ef77aaa866be5ad4b4bb99a9f62a a.pdf.

- Ágh, Attila. 2010. "Europeanization and Democratisation in ECE: Towards Multi-level and Multi-actor Governance." The N ISPA cee Journal of Public Administration and Policy III (1): 7-29. Accessed October 10, 2017. https:/ / www.degruyter.com/downloadpdf/j/nispa.2010.3.issue-1/v10110-0100001-1/v10110-010-0001-1.pdf. 
- $\quad$ Andrei, Cristian. 2013. "Document exclusiv. Guvernul pregătește marea descentralizare" [Exclusive document. The government is preparing the great decentralisation]. $\quad 30 \quad$ September. Accessed November 11. http:/ / www.gandul.info/politica/document-exclusiv-guvernul-pregatestemarea-descentralizare-11418809.

- $\quad$ Andrei, Tudorel, Marius Profiroiu, and Mihai Turturean. 2006. „Reforma administrației publice locale. Cazul României" [Reform of local public administration. The case of Romania]. Economie teoretică şi aplicată [Theoretical and applied economy] 2 (497): 55-64.

- $\quad$ Asociația Pro Democrația, Agenția de Monitorizare a Presei, Centrul de Resurse pentru Participare Publică. 2007. „Buna guvernare la români. Principii, metodologie şi studii de caz" [Good governance in Romania. Principles, methodology and case studies]. Bucureşti. Accessed October 12, 2015. http:/ / www.apd.ro/files/publicatii/Buna_guvernare_la_romani.pdf.

- "Autoritățile locale vor libertate de la Guvern pentru fonduri UE." 2009. [Local authorities want freedom from the Government for EU funds], 08 $\begin{array}{llll}\text { September. } & \text { Accessed November } & \text { 19, }\end{array}$ http:/ / incomemagazine.ro/articles/autoritatile-locale-vor-libertate-de-laguvern-pentru-fonduri-ue.

- Balogh, Marton. 2000. “Apariția politicilor de dezvoltare regională și rolul regiunilor în Europa Centrală și de Est" [The emergence of regional development policies and the role of the regions in Central and Eastern Europe]. Revista Transilvană de Științe A dministrative 1 (4): 7-17. Accessed October 21, 2017. http:/ / rtsa.ro/rtsa/index.php/rtsa/article/view/404/399.

- $\quad$ Battilana, Julie, and Tiziana Casciaro. 2012. "Change Agents, Networks and Institutions: A Contingency Theory of Organizatioal Change." A cademy of M anagement Journal 2 (55): 381-398.

- Berceanu, Bogdan. 2012. "Emerging Administrations under European Union Rules." The 7th Edition of the International Conference European Integration, Realities and Perspectives. Reforming Public Administration. Accessed October 09, 2017. http://www.proceedings.univdanubius.ro/index.php/eirp/article/viewFile/1331/1279.

- Bosovcki, Amanda. 2009. „Administrația publică din România între europenizare şi rezistență la schimbare" [Romanian public administration between Europeanisation and resistance to change]. Sfera Politicii 131-132. Accessed October 08, 2014. http://www.sferapoliticii.ro/sfera/131-132/art12bosovcki.html. 
- Bouckaert, Geert, Vitalis Nakrošis, and Juraj Nemec. 2011. "Public Administration and Management Reforms in CEE: Main Trajectories and Results." The NISPA cee Journal of Public Administration and Policy IV (1): 9-29. Accessed October 10 , 2017. https:/ / www.degruyter.com/downloadpdf/j/nispa.2011.4.issue-1/v10110-0110001-9/v10110-011-0001-9.pdf

- Búkfeyes-Rákossy, Zombor. 2015. Realităţi și perspective ale regionalizării României [Realities and perspectives regarding the regionalisation of Romania]. Revista Transilvană de Științe Administrative 2 (37): 28-37. Accessed October 23, 2017. http:/ / rtsa.ro/rtsa/index.php/rtsa/article/view/509/506.

- Cardona, Francisco. 2009. „Integrating National Administrations into the European Administrative Space." Conference on Public Administration Reform and European Integration Budva, Montenegro 26-27 March 2009. Accessed November 10, 2015. http:/ / www.sigmaweb.org/publications/42747690.pdf.

- Comisia Europeană. 2015. „Extindere. Politica de extindere. Criterii de aderare." [Enlargement. The policy of enlargement. Criteria for accession]. Accessed October 12, 2015. http://ec.europa.eu/enlargement/thepolicy/conditions-for-enlargement/index_ro.htm.

- $\quad$ Comitetul Tehnic Interministerial pentru Regionalizare-Descentralizare (CTIRD). 2015. "Misiune" [Mission]. Accessed November 18. http:/ / regionalizare.mdrap.ro/ctird/misiune/.

- $\quad$ Common Assessment Network (CAF). 2017. Accessed October 31. http:/ / www.eipa.eu/en/topic/show/\&tid=191.

- Consiliul Legislativ Român (CLR). 2015. "Capitolele de negociere ce definesc acquis-ul comunitar" [Chapters of negotiations defining the Community Acquis]. Accessed November 18. http:/ / www.clr.ro/menu1/HtmlPage6.htm.

- Dogot, Cristina-Maria. 2006. "Central and East Europe, the State, and the Challenges of Modernity." In The N ew Central and East European Culture, edited by Steven Tötösy De Zepetnek, Carmen Andras, and Magdalena Markovszky, 100-112. Aachen: Shaker Verlag.

Dogot, Cristina-Maria. 2013. „Economic and Technocratic Leadership at Borderland." In The Frontier W orker - N ew Perspectives on the Labor M arket in the Border Regions, edited by Adrian-Claudiu Popoviciu and Dana Cigan, 81-96. Bucharest: Ed. C.H. Beck.

- $\quad$ Elbasani, Arolda. 2009. "EU Administrative Conditionality and Domestic Downloading. The Limits of Europeanization in Challenging Contexts." KFG 
Working Paper 2 (July): 3-21. Accessed October 28, 2017. http://userpage.fuberlin.de/kfgeu/kfgwp/wpseries/WorkingPaperKFG_2.pdf.

- $\quad$ European Association for Public Administration Accreditation. 2017. Accessed October 31. http://www.eapaa.eu/.

- European Commission. 2015. „EU - Romania Relations.” Accessed October 03, 2015. http://ec.europa.eu/enlargement/archives/romania/eu_romania_relations_en. htm.

- European Commission. 2016. Quality of Public Administration. 14 November. Accessed October 09, 2017. https://ec.europa.eu/info/sites/info/files/european-semester_thematicfactsheet_quality-public-administration_en.pdf.

- $\quad$ European Council. 1999. "Presidency Conclusions. Helsinki European Council 10 and 11 December 1999." Accessed October 03, 2015. http://www.consilium.europa.eu/en/uedocs/cms_data/docs/pressdata/en/ec /acfa4c.htm.

- $\quad$ European Institute of Public Administration. 2017. Accessed November 30. http://www.eipa.eu/.

- $\quad$ European Parliament. 1993. „Copenhagen European Council - 21-22 June 1993. Presidency Conclusions." Accessed October 10, 2015. http://www.europarl.europa.eu/enlargement/ec/cop_en.htm.

- $\quad$ European Public Administration Network. 2017. Accessed October 03, 2017. http://www.eupan.eu/.

- $\quad$ Filip, Gheorghe, and Mihaela Onofrei. 2000. "Fenomenul birocratic în contextul modernizării sistemelor administrative" [Bureaucratic phenomenon in the context of modernising the administrative systems]. Revista Transilvană de Stiințe Administrative 1 (3): 111-118. Accessed October 21, 217. http://rtsa.ro/rtsa/index.php/rtsa/article/view/436/431.

- $\quad$ Fuerea, Augustin, Steliana Sandu, Cezar Scarlat, Gheorghe Hurduzeu, Cristian Păun, and Roxana-Mariana Popescu. 2004. „Evaluarea gradului de concordanță a legislației române cu acquis-ul comunitar, la nivelul anului 2002, pe capitole de negociere" [Assessment of compliance of Romanian legislation with the Community Acquis, in 2002, by negotiating chapters]. Studii de impact (PAIS II). București: Institutul European din România. Accessed November 12. http://beta.ier.ro/documente/studiideimpactPaisII_ro/Pais2_studiu_1_ro.pdf.

- Garaiman, Roxana. 2013. „Zona Metropolitană București scoasă de la nafalină de primarul Oprescu" [Bucharest Metropolitan Area removed from 
naphthalene by Mayor Oprescu]. Business24, 18 October. Accessed November 15, 2015. http://www.business24.ro/administratie/primaria/zona-metropolitanabucuresti-scoasa-de-la-naftalina-de-primarul-oprescu-1536621.

- Goetz, Klaus H. 2001. "Making Sense of Post-communist Central Administration: Modernization, Europeanization or Latinization?" Journal of European Public Policy 8 (6): 1032-1051.

- Goudenhooft, Gabriela. 2009. "A Psychological Interpretation of the Administration Science: The Reform of the Representations." Transylvanian Review of A dministrative Sciences no. 26: 70-81.

- Guvernul României. Ministerul Administrației Publice. 2015. „Strategia Guvernului privind informatizarea administrației publice" [Strategy of government to digitalise the public administration]. Accessed October 10, 2015. http://gov.ro/fisiere/programe_fisiere/e-administration.pdf.

- Hințea, Călin, and Cristina Mora. 2005. "Cultura organizațională în administrația publică" [Organisational culture in public administration]. Revista Transilvană de Științe Administrative 1 (13): 81-86. Accessed October 21, 2017. http://rtsa.ro/rtsa/index.php/rtsa/article/view/216/211.

- Hințea, Călin. 1999. "Probleme strategice ale reformei sistemului administrative românesc" [Strategic issues of the reform of Romanian administrative system]. Revista Transilvană de Științe A dministrative 1 (2): 141-145. Accessed October 21 ,

2017. http://rtsa.ro/rtsa/index.php/rtsa/article/view/458/453.

- Hințea, Călin Emilian, and Sorin Dan Șandor. 2000. "Reformă și administrație publică" [Reform and public administration]. Revista Transilvană de Științe Administrative 1 (3): 29-44. Accessed October 21, 2017. http://rtsa.ro/rtsa/index.php/rtsa/article/view/430/425.

- Hințea, Călin, Sorin Dan Șandor, and Veronica Junjan. 2002. "Administrative reform in Romania and the European Union." Revista Transilvană de Științe Administrative 1 (7): 54-74. Accessed October 21, 2017. http://rtsa.ro/rtsa/index.php/rtsa/article/view/348/343.

- Hințea, Călin E., and Bogdana Neamțu. 2014/2015. “Strategic Planning in the Framework of Metropolitan Areas of Romania: Going beyond the Requirements of the Law and Transforming it into an Effective Planning Tool." The NISPA cee Journal of Public A dministration and Policy VII (2): 71-97. Accessed October 10 , 2017. https://www.degruyter.com/downloadpdf/j/nispa.2014.7.issue-2/nispa-20140004/nispa-2014-0004.pdf. 
- Hudrea, Adrian. 2014. "Studiul și analiza culturii organizaționale" [The study and analysis of organisational culture]. Revista Transilvană de Științe Administrative 2 (35): 29-39. Accessed October 22, 2017. http:/ /rtsa.ro/rtsa/index.php/rtsa/article/view/480/477.

- $\quad$ Indaco LegeStart. 2015. Accessed October 02, 2015.

- "Instrumente juridice semnate şi ratificate de România." 2015. [Legal instruments signed and ratified by Romania]. Accessed October 23, 2015. http:/ / coe.mae.ro/node/1250.

- Ion, Oana-Andreea. 2015. „Europenizarea: un proces, mai multe întrebări” [Europenization: one process, more questions]. In Europenizarea. Studii de guvernare si securitate [Europenization. Governance and Security Studies], edited by Anglițoiu, George, 1-17. Bucharest: CH Beck, Strategic Studies Series.

- Ion, Oana-Andreea. 2013. Abordări actuale ale guvernanți U niunii Europene [Current Approaches to the Governance of the European Union]. Iași, Ed. Polirom.

- Ionescu, Vladimir. 2015. „Prima ședință de guvern: Reforma administrației - Vasile Dîncu, solicitat să gândească principiile, Aura Răducu, să o aplice la administrarea fondurilor europene" [The first meeting of government: Administration Reform - Vasile Dîncu asked to think about the principles, Aura Răducu to apply it to the administration of EU funds], 19 November. Accessed November 19, 2015. http://cursdeguvernare.ro/prima-sedinta-de-guvernreforma-administratiei-vasile-dincu-solicitat-sa-gandeasca-principiile-auraraducu-sa-o-aplice-la-administrarea-fondurilor-europene.html.

- Knill, Christoph. 2001. The Europeanisation of $\mathrm{N}$ ational Administrations. Patterns of Institutional Change and Persistance. New York: Cambridge University Press.

- Legea 315/2004, privind dezvoltarea regională în România [Law 315/2004 on regional development in Romania]. Accessed November 18, 2015. http:/ /lege5.ro/Gratuit/gu3domrv/legea-nr-315-2004-privind-dezvoltarearegionala-in-romania.

- Legea Zonei Metropolitane București. 2015. [Law of Bucharest Metropolitan Area] in: http://zmb.ro/main.php?display=proiect_final. Downloaded: 15/11/3015.

- Miclăuș, Gheorghe, and Nicolae Horea. 2000. „Instrumente de cooperare ale colectivităţilor locale şi regionale în cadrul național şi internațional” [Tools of cooperation for local and regional units within the national and international 
framework]. Revista transilvană de ştiințe administrative 2 (4): 81-91. http://rtsa.ro/rtsa/index.php/rtsa/article/view/411.

- Ministerul Dezvoltării Regionale și Administrației Publice (MDRAP). 2015a. Accessed November 18, 2015. http:/ / www.mdrap.gov.ro/.

- _ - _ 2015b. "Când se vor constitui regiunile?.” [When will regions be established?]. Accessed November 2015. http:/ / regionalizare.mdrap.ro/despre-regionalizare/cand-se-vor-constituiregiunile/.

- Moldovan, Octavian, and Felicia Cornelia Macarie. 2016. "Cultura organizațională în administrația publică: o analiză comparativă" [Organisational culture in public administration: a comparative analysis]. Revista transilvană de ştiințe administrative 2 (39): 123-139. Accessed October 23, 2017. http:/ /rtsa.ro/rtsa/index.php/rtsa/article/view/536/533.

- Nakrošis, Vitalis, and Sabina Bankauskaitè-Grigaliūnienè. 2014. "Public Administrations Changes and the Impact of the EU: Agencification and Depoliticisation in Central and Eastern Europe." Paper for the ECPR joint sessions (Salamanca, 2014), Vilnius. Accessed October 08, 2015. https:/ / ecpr.eu/Filestore/PaperProposal/5a110089-7378-41af-ba367e39f13612a5.pdf.

- The Network of Institutes of and Schools of Public Administration in Central and Eastern Europe. 2017. Accessed October 03, 2017. http://www.nispa.org/.

- $\quad$ Pasti, Vladimir. 1995. România în tranziție. Căderea în viitor [Romania in transition. The fail in the future], Bucureşti, Ed. Nemira.

- $\quad$ Pollack, Mark A. 2005. "Theorizing EU Policy-Making." In Policy M aking in the European U nion, edited by Helen Wallace, William Wallace, and Mark A. Pollack, 13-48. Oxford: Oxford University Press.

- Popa, Florin Marius. 2017. "Assessment of Public Administration Integrity Level: Between Morality and the Law." Romanian Journal of Public A ffairs no. 1: 28-36.

- $\quad$ Portalul Național de Administrație Publică [National Portal of Public Administration]. 2015. Accessed

October

31. http:/ / www.administratie.ro/cautare.php.

- $\quad$ Portalul Național de Administrație Publică (PNAP). 2005a. “ADECJR a editat o broșură privind analiza managerială a administrației publice locale" [ADECJR edited a brochure on local government management analysis], 31 
March. Accessed November 15, 2015. http:/ / www.administratie.ro/articol.php?id=277\&indentifica=descentralizare. - - - 2013a. „A fost înființat CONREG, organism strategic prevăzut în Memorandumul privind procesul de regionalizare" [CONREG was established, a strategic body provided in the Memorandum on the process of regionalisation]. Accessed November

04, 2015. http:/ / www.administratie.ro/articol.php?id=42628\&indentifica=regionalizare. - - - - 2013b. „Asociația Oraşelor din România se declară împotriva adoptării actualului proiect de lege privind descentralizarea" [Association of Towns from Romania are against the adoption of the current draft law on decentralisation]. 04 November. Accessed November 19, 2015. http:/ / www.administratie.ro/articol.php?id=45158\&indentifica=descentralizare

- - - 2014a. “CCR a decis că legea descentralizării încalcă principiul autonomiei locale, al legalității şi regimul proprietății" [CCR decided that the law of decentralisation violates the principle of local autonomy, of legality and property]. 12 January. Accessed November 19, 2015. http:/ / www.administratie.ro/articol.php?id=45771\&indentifica=descentralizare

- - C-. 2013c. „Cristian Pârvulescu: 'Până acum, împărțirea României s-a făcut în mod arbitrar'" [Until now, the division of Romanian territory was arbitrary]. 04 March. Accessed November 12, 2015. http:/ / www.administratie.ro/articol.php?id=42775\&indentifica=regionalizare.

- - - 2006. „Deputați PNL lucrează la un proiect de lege pentru regionalizarea țării" [Liberal MPs working on a bill to regionalize the country]. $05 \quad$ June. Accessed November 01, 2015. http:/ / www.administratie.ro/articol.php?id=8761\&indentifica=regionalizare. - $\quad$ - —. 2010a. "Descentralizarea a fost principala temă abordată la reuniunea Asociației Orașelor din România" [Decentralization was the main topic discussed at the meeting of the Association of Towns from Romania]. 25 January. Accessed November 19, 2015. http:/ / www.administratie.ro/articol.php?id=29356\&indentifica=descentralizare

- - - 2005b. "Descentralizarea va fi finalizată până în 2008, potrivit unui proiect de lege" [According to a bill, decentralisation will be completed by 2008], 03 November. Accessed Noember 19, 2015. http:/ / www.administratie.ro/articol.php?id=4574\&indentifica=descentralizare. 
- - - - 2005c. "Dezvoltare metropolitană în Romania" [Metropolitan development in Romania], 31 October. Accessed November 15, 2015. http:/ / www.administratie.ro/articol.php?id=4519\&indentifica=descentralizare.

- - —. 2011a. "Emil Boc: 'Dacă nu facem reorganizarea administrativteritorială, România îşi diminuează şansele de a mai accesa fonduri europene'" [Emil Boc: 'If we fail to do the administrative-territorial reorganisation, Romania diminishes its chances to access European funds'], 07 June. Accessed November 19 ,

2015.

http:/ / www.administratie.ro/articol.php?id=36520\&indentifica=descentralizare

- $\quad$ - - 2011b. „Fostul director al INA: 'Regionalizarea este necesară numai pentru a duce la dezvoltarea socio-economică'" [Former director of INA: 'Regionalisation is necessary only to lead to socio-economic development']. 09 June. Accessed November 03, 2015. http:/ / www.administratie.ro/articol.php?id=36544\&indentifica=regionalizare.

- - - . 2011c. "Gheorghe Nichita: 'Regionalizarea este aruncată în derizoriu de către guvernanți'" [Regionalisation is a mockery of the governors]. 16 June. Accessed November 03, 2015. http:/ / www.administratie.ro/articol.php?id=36625\&indentifica=regionalizare. - $\quad$ - - . 2013d. „Klaus Iohannis despre regionalizare: 'Aproape sigur că nu o facem anul acesta, dar nu există un risc de a pierde banii UE'" [Klaus Johannis about regionalization: 'Almost certainly we will not do it this year, but there is no risk of losing EU money']. 02 August. Accessed November 14, 2015. http:/ / www.administratie.ro/articol.php?id=44250\&indentifica=regionalizare.

- $\quad$ - - - 2014b. "Klaus Iohannis crede că regionalizarea nu se va face anul acesta, 'din cauza alegerilor'" [Klaus Johannis believes that regionalisation will done not be this year, 'because of the election']. 23 January. Accessed November 14 , 2015. http://www.administratie.ro/articol.php?id=45909\&indentifica=regionalizare. - - —. 2013e. „Liviu Dragnea: 'România este dezvoltată dezechilibrat, abordarea față de regionalizare e diferită față de începutul anului'" [Liviu Dragnea: 'Romania is unequally developed, the approach towards regionalisation is different from the beginning of this year']. 24 October. Accessed November 14, 2015. http:/ / www.administratie.ro/articol.php?id=45052\&indentifica=regionalizare.

- - - . 2013f. „MDRAP a lansat pe site-ul propriu secțiunea regionalizare-descentralizare" [MDRAP released on its website a section on 
regionalisation-decentralisation]. 16 May. Accessed October 11, 2015. http:/ / www.administratie.ro/articol.php?id=43546\&indentifica=regionalizare.

- - —. 2013g. „Ministrul Liviu Dragnea explică de ce regiunile din România trebuie să fie funcționale până în decembrie 2013" [Minister Liviu Dragnea explains why Romanian regions have to work until December 2013]. Accessed November 03, 2015. http:/ / www.administratie.ro/articol.php?id=42352\&indentifica=regionalizare.

- - - — 2008. "Nu a existat dorința de a reforma administrația" [There was no will to reform administration]. 10 November. Accessed November 19, 2015.

http:// www.administratie.ro/articol.php?id=22598\&indentifica=descentralizare

- - - 2015a. "Obiectivele și principiile Programului de guvernare propus de Cabinetul Cioloș" [The objectives and principles of governing program proposed by the Cioloş Cabinet]. 16 November. Accessed November 19, 2015.

http:/ / www.administratie.ro/articol.php?id=50772\&indentifica=descentralizare

- - - - 2015b. "O delegație a Asociației Municipiilor din România a avut o întâlnire cu vicepremierul Vasile Dîncu" [A delegation of the Association of Towns from Romania had a meeting with the vice-prime-minister Vasile Dîncu]. 13 December. Accessed December 13, 2015. http:/ / www.administratie.ro/articol.php?id=50953.

- - _ - 2010b. "Primarii oraşelor mici sunt nemulțumiți că nu au fonduri şi că nu există descentralizare locală" [Mayors of small towns are unhappy that they have no funds and there is no local decentralisation]. 12 March. Accessed November 19 , 2015. http:/ / www.administratie.ro/articol.php?id=30263\&indentifica=descentralizare

- - - - 2013h. „Procesul de descentralizare a fost discutat de conducerea MDRAP cu asociațiile administrat,iei publice locale" [The decentralization process has been discussed by the management of local government associations MDRAP]. $23 \quad$ April. Accessed November 19, 2015. http:/ / www.administratie.ro/articol.php?id=43371\&indentifica=descentralizare

- - - 2 2013i. "Românii au mari aşteptări de la regionalizare” [Romanians have high expectations from regionalization]. 12 April Accessed 
October

12 ,

2015

http:/ / www.administratie.ro/ articol.php?id=43245\&indentifica=regionalizare.

- ———. 2013j. „Vasile Dâncu: "Regionalizarea trebuie să vizeze în primul rând modernizarea administrației'" [Regionalization should primarily focus on the modernization of administration]. 29 March. Accessed November 14 ,

2015

http:/ / www.administratie.ro/articol.php?id=43079\&indentifica=regionalizare.

- - - . 2014c. "Vicepremierul Liviu Dragnea speră că 2015 va fi anul în care se vor finaliza descentralizarea şi regionalizarea" [Vice-prime-minister Liviu Dragnea hopes that 2015 will be the year that will complete decentralisation and regionalisation]. 14 September. Accessed November 14, 2015. http:/ / www.administratie.ro/articol.php?id=47731\&indentifica=regionalizare.

- - - 2015c. "Victor Paul Dobre: 'Administrația publică, atât centrală cât şi locală, şi-a atins limitele'" [Victor Paul Dobre: 'Public administration, both central and local government, has reached its limits']. 15 October. Accessed November 14 , 2015 http:/ / www.administratie.ro/articol.php?id=50486\&indentifica=regionalizare. - - - . 2014d. "Victor Ponta: 'În 2015 chiar trebuie să facem descentralizarea'" [Victor Ponta: 'In 2015 we really need to realise decentralisation']. 29 June. Accessed November 19, 2015. http:/ / www.administratie.ro/articol.php?id=47419\&indentifica=descentralizare

- Profiroiu, Marius. 2002. „Accelerarea reformei administrației publice” [Acceleration of reforms of public administration]. Revista Transilvană de Științe Administrative 2 (8): 13-23. Accessed November 23, 2015. http://rtsa.ro/rtsa/index.php/rtsa/article/view/318/313.

- Radaelli, Claudio M. 2004. „Europeanisation: Solution or Problem?” European Integration online Papers (EIoP), 16 (8). Accessed October 12, 2015. http://eiop.or.at/eiop/texte/2004-016a.htm.

- Săgeată, Radu. 2012. "Reformele administrative din România - între rațiunile politice și realitățile geografice" [Administrative reforms in Romania between political motivation and geographical realities]. Geograful III (1-2): 3-26. Accessed October 28, 2017. http://apgr.eu/downloads/Geograful\%20_1_2_2011.pdf.

- $\quad$ SIGMA-OECD. 1998. „Principiile europene în administrația publică” [European principles in public administration]. Paris. 
- Societatea Academică din România (SAR). 2013. "Raport anual 2013" [Annual report 2013]. Accessed November 18, 2015. http://sar.org.ro/wpcontent/uploads/2013/03/RAPORT-SAR_FINAL.pdf.

- "Strategia Guvernului privind accelerarea reformei în administrația publică" [Strategy of government to accelerate the reform in public $\begin{array}{llll}\text { administration]. } & \text { Accessed } & \text { October } & 1015 .\end{array}$ http:/ / gov.ro/fisiere/programe_fisiere/reforma-admin-public.pdf.

- S S Sandor, Dan, and Călin Hințea. 1999. "Profesionalizarea funcționarilor publici" [Professionalization of public officials]. Revista Transilvană de Științe Administrative 1 (2): 83-93. Accessed October 21, 2017. http:/ /rtsa.ro/rtsa/index.php/rtsa/article/view/453/448.

- S Sandor, Sorin Dan, and Ciprian Tripon. 2007. "Pași spre construirea unui model operațional al reformei administrației publice" [Steps to build an operational model of public administration reform]. Revista Transilvană de Știinte Administrative 1 (19): 92-106. Accessed October 21, 2017. http:/ /rtsa.ro/rtsa/index.php/rtsa/article/view/165/161.

- Șuta, Ștefan. 1998. "Necesitatea profesionalizării și reformei administrației publice" [Need for professionalization and public administration reform]. Revista Transilvană de Științe Administrative 1 (1): 11-19. Accessed October 21, 2017. http:/ / rtsa.ro/rtsa/index.php/rtsa/article/view/371/366.

- Tripon, Ciprian, and Călin Ghiolțan. 1999. "Rezistența la schimbare" [Resistance to change]. Revista Transilvană de Științe A dministrative 1 (2): 94-115. Accessed October 21, 2017. http://rtsa.ro/rtsa/index.php/rtsa/article/view/454/449.

- Warner, Martin, Cezar Scarlat, and Daniel Popescu. 2015. "Implicații ale aderării României la UE asupra instituțiilor din administrația publică" [Implications of Romania's EU accession on public administration institutions]. Accessed October 21, 2015. http:/ / beta.ier.ro/documente/studiideimpactPaisI_ro/Pais1_studiu_B-5_ro.pdf. 


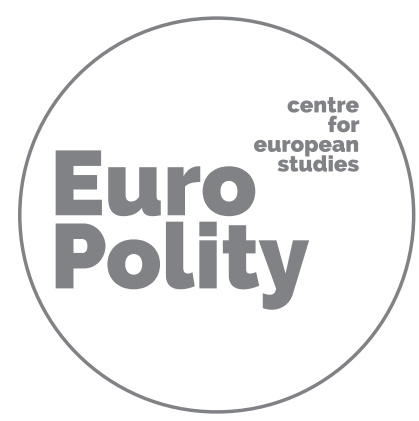




\title{
GEOPOLITICS AT THE EASTERN BORDERS OF THE EUROPEAN UNION : EASTERN EUROPE BETWEEN THE EU AND RUSSIA 1
}

\author{
Dacian D una \\ Babes-Bolyai University \\ Cluj-Napoca/Romania \\ dunadacian@yahoo.com
}

\begin{abstract}
Geopolitics has changed dramatically over the last century, from a modernist discipline focused on the impact of geography on politics and international relations, to a postmodern approach in which traditional assumptions of reality are getting blurred, like the in-out distinction, borders are getting permeable, and state-centrism is replaced by multiplicity. A postmodern actor such as the European Union provides a good example of the sort. The EU has managed to assimilate most of the instruments and policies developed during the course of European integration, including regional policy, or cross-border cooperation, a territorial approach to development across the border regions of Europe pioneered by the Council of Europe since the 1950s. This paper tries to compare the policies of the European Union pre- and post-enlargement regarding Eastern Europe, using a geopolitical approach, questioning whether the recent
\end{abstract}

${ }^{1}$ The present paper is published under the framework of Jean Monnet Centre of Excelence "In and Out: Understanding the European Union Beyond Its Borders", nr. 565330-EPP-1-2015-1-RO-EPPJM O-COE 
geopolitical resurgence of Russia has the potential to question the influence of the European Union over its Eastern neighbourhood.

\section{Keywords}

Enlargement, fragmentation, neighbourhood, geopolitics, EU, Eastern Europe, CBC, integration,

\section{INTRODUCTION}

Globalization is undisputedly one of the processes that shape the present of our planet. It is the logical development of a large sum of events, patterns and trends that took place since the times of the industrial revolution. The victory of the Western model of society - a model based on political and economic liberalism - over its totalitarian rivals once promised a peaceful global order that would last forever. Many political thinkers and practitioners anticipated the end of geopolitics, not only the end of history. They referred to that kind of geopolitics that divided the world into camps as becoming obsolete. However, have the last years witnessed the "revenge of geography" as Robert Kaplan argued (Kaplan 2012), or maybe the revenge of geo-strategy, that sub-field of geopolitics studied by the infamous school of geopolitics of general Haushofer? Is this what is happening in Eastern Europe, especially in the areas that remained outside the enlargements of the Western institutions? Or in fact geopolitics was never abandoned? These are some of the questions that still need answers. Unfortunately, the honeymoon between ,East' and ,West' seems now long gone and the events that took place not long ago in Georgia or Ukraine are potentially hazardous for the whole of Europe. The policies of the Western organizations have not been able to prevent them.

Looking back to the last decades one could hardly miss that geopolitics as discipline and practice has returned, though fundamentally changed. It was an epistemological change. Geopolitics came back to the centre of analysing the global space with the help of critical geopolitics. However, as the promise of neoliberalism with its focus on geo-economics failed to materialize, classical geopolitics returned as well. 
Classical geopolitics "rests upon the relative spatial positions of countries, regions, and resources as these may affect their foreign policies and actions. Such terms as states' and regions' locations, topography, distance, shape, and size will accompany these geographic features. And within these spatial structures, we may see certain patterns as depicted in shatterbelts, buffers, heartlands, sea power and land power, and checkerboards, among the numerous concepts-theories attached to the study of geopolitics" (Kelly 2016, 2). Another definition, provided by Saul B. Cohen, is even more instrumental for our analysis. According to Cohen, geopolitics is "the analysis of the interaction between, on the one hand, geographical settings and perspectives and, on the other, political processes. The settings are composed of geographical features and patterns and the multilayered regions that they form. The political processes include forces that operate at the international level and those on the domestic scene that influence international behaviour" (Cohen 2015, 16). Clearly, the focus of this paper falls on the linkage between the European integration process and the multi-layered geopolitical realities of Eastern Europe.

On the other hand, critical geopolitics deconstructed the modernist assumptions and meanings used in the theory and practice of geopolitics and statecraft. According to Toal, critical geopolitics has taken up the challenge "to document and deconstruct the institutional, technological, and material forms of these new congealments of geo-power, to problematize how global space is incessantly reimagined and rewritten by centers of power and authority in the late twentieth century" (Toal 1996, 196). Critical geopolitics is a new representation of "geopolitics as a discourse comprising two overlapping components. First, the 'practical geopolitics' of everyday statescraft, whereby the world is spatialized into regions with imagined attributes and characteristics-leading to a mosaic of places of 'danger', 'threat', or 'safety' that underpins foreign policy. Second, the 'formal geopolitics' created by 'security intellectuals' who produced theories and strategies to guide and justify the statecraft of practical geopolitics" (Ó Tuathail and Agnew 1992 in Dodds, Atkinson 2000, 10). Critical or postmodern geopolitics seem to better describe the geopolitical features of a postmodern actor such as the European Union.

Eastern Europe has always been an object of dispute between the empires of Western Eurasia. The appearance of emancipation felt after the Cold War inside the region has soon proved to be an illusion. The region is still parcelled between the interests of the Western organizations and those of the Russian Federation. It remained caught between two discourses with geopolitical implications. On the one hand, the 
discourse of a metaphorical empire, as Ole Waever would argue, based on liberalism, conditionality and differentiation, the European Union. On the other hand, the discourse of an old empire, championing the old ways, the conservative values, against the so-called Western decadence, the Russian Federation. The dilemma remains largely economic, since the most important problem of Eastern Europe is its constant dependence on energy, technology, and investments due to its historical poorness. For the most part of the period (1990-2010) the East European nations had mostly depended on the EU, but since the European economic crisis the credibility of the European Union did show signs of fluctuations. Austerity dramatically changed the behaviour of the European institutions not only in what concerns fiscal discipline within the Member States of the EU but also in terms of its external relations. The EU is far less generous with its current Eastern neighbours than it used to be in the 1990s with the countries of Central Europe.

This paper is approaching the policies of the European institutions, particularly those of the European Community and the European Union with regard to Eastern Europe after the fall of communism and the breakup of the Soviet Union using geopolitical lenses.

\section{DIFFERENTIATION AND CONDITIONALITY}

Since the early 1990s the European Union has had to define its relations with the neighbouring areas in a wide spectrum of issues and using a complex mixture of policies. Among them were the CFSP-CSDP, the regional policy, the cross-border cooperation policy, JHA and so. The EU was not alone in this matter. It was accompanied and still is by a plethora of IGOs, INGOs, corporations, or firms. The most important companions added consistence to the Western approach of Eastern Europe: The North Atlantic Alliance (NATO), the Council of Europe, or OSCE, covering all the aspects necessary for strengthening the East-West rapprochement after the long decades of the Cold War. This evolution was actually the Western feedback following the input received from the ,East'. A number of Central European countries, namely Poland, Czechoslovakia (before the split), and Hungary had noticed the openness of the Western institutions soon after the fall of communism, 
cooperating together to join the Euro-Atlantic institutions while at the same time preparing their societies for political liberalism and market economy.

In this atmosphere it seemed the West was once again embracing the East. However, the process was not a smooth one. It soon became clear that Eastern Europe has not been a monolith after all during the times of the Cold War. The monolith was cracked and the demise of communism made it implode. The Western institutions came soon to realize that Eastern Europe was regionally diversified and a process of differentiation was soon employed in the relations with the East. According to Peter Gowan (Gowan 2002, 29-30) the Eastern Europe was split into several sub-areas from Europe's point of view:

- The Frontier Belt formed by states neighbouring directly Germany and/or Austria: Poland, Czech Republic, Slovakia, Hungary, and Slovenia. Croatia's involvement in the Western Balkans' wars gave it for a moment an economic, political, and strategic profile different from other frontier belt states;

- South-Eastern Europe and the Western Balkans: this area includes Romania and Bulgaria, Albania, and all the successor countries of Yugoslavia, except Slovenia;

- The Baltic region: the Baltic states and Kaliningrad;

- The Western part of the CIS: Russia, Ukraine, Belarus, and Moldova;

- The Caucasus: especially Armenia, Georgia, and Azerbaijan.

The regional differentiation noticed by Gowan may have been once a reality from the point of view of European and Atlantic institutions. Obviously, the reality changed dramatically, once Romania, Bulgaria, Croatia, and Albania joined the European Union and/or NATO. What is important is the fact that the regional differentiation operated by the European institutions probably covered some geopolitical considerations along the classical economic or political ones (specific to a civilian power such as the EU). This policy of regional differentiation reflects the gradual extension of European Union's interest towards its Eastern European neighbours after the end of communism in Eastern Europe. This interest was getting compartmentalized depending on regional circumstances. Not surprisingly, the main target for the EU enlargement policy was initially the Central European sub-region, mainly because its countries had rapidly succeeded in cooperating in a joint manner with a view to their admission to the European and Atlantic organizations (using 
such initiatives as the Visegrad Group, CEFTA, or the Central European Initiative). Yet, probably the most important argument was the fact that this frontier belt' countries could have formed the first line of defence in the wake of the new crossborder security threats foreshadowing the Eastern border of the Union in the early 1990s.

After the fall of Berlin Wall some voices had suggested a new historical and "natural" divide (as Milan Kundera argued) between East and West, or a new wall separating the "Cosmos" from "Chaos". Especially the Northern countries hurried to create regional cooperation initiatives in the Baltic and Barents seas beyond the new "big cultural division." The regional institutions were regarded as instruments to approach the problems of the chaotic "Other", but also "meeting points" of "interface" between different political cultures and old enemies (Tunander, 1997, 27). Immediately after the Cold War there was a temptation from the West to divide Europe - this time into three parts: the West, a restricted Central Europe that was expected to share the Western political culture (the Visegrad Group), and a new Eastern Europe (described as chaotic, unstable, based on the Eastern political culture). Gradually the European institutions have realized that they were the only entities able to order the "Chaos" of the neighbouring regions. The enlargement served this goal. Moreover, the narrowed sense of Central Europe was gradually abandoned as the European and Atlantic institutions have found the necessity to strengthen the new fragile democracies of Central and Eastern Europe in order to isolate the areas of risk for the European security.

Ola Tunander, a former researcher of the Peace Research Institute Oslo (PRIO), anticipated the new geopolitical division lines of the post-Cold War era: 1) NATO $\leftrightarrow$ Russia - focus on Germany, Northern Europe and Central Europe; 2) Europe $\leftrightarrow$ Islam - focus on Latin Southern Europe; 3) Limes Romanus $\leftrightarrow$ Limes Germanicus ${ }^{1}$ caused by the accent on either the North or the South of Europe, resulting in tensions within the EU (Tunander 1997, 24). The European political establishment categorically refused to formulate such dilemmas in geopolitical terms (politically

${ }^{1}$ During the Roman Empire, limes (spelled in English /'las mis/) was the frontier separating the Roman world from the Northern barbarian world ('Barbaricum'). 
incorrect). However, a close-up inspection of the regional policies developed by the European and Atlantic organizations in the last decades provides the evidence of an approach as the one remarked by Tunander. After the Cold War there was a period during which high-security or geostrategic concerns were no longer present. Instead, the type of threats to security has significantly changed, the concerns over microsecurity, or low security, have generously occupied the agenda. The states beyond the borders of Europe were no longer the most acute danger for the Western European security. The main danger came from the criminal activities developed within their borders with an important transnational impact.

Given that European integration also implied the adoption of the Schengen acquis, it is understandable that the enlargement of the EU has awakened many anxieties in the West. The two major concerns of the EU have become cross-border migration and crime (the latter covering a large number of issues including smuggling, human trafficking, drugs, terrorism, etc.), border control being considered by the Union as the main line of defence against instability and its consequences: refugees, murder and the collapse of law and order (Grabbe 2000). Although not all of these anxieties were not properly associated with the opening of borders to EU candidate countries, they have not lost their importance. Not by accident, the securing of borders with non-member states has become a priority for candidates' accession negotiations, and cross-border cooperation has become a major component of the relations between the EU and its neighbours.

The institutionalization of Nordic / Baltic security was also a reaction to the tragic experience of the Western Balkans. The Nordic people have shown their lack of interest in what was going on in southern Europe. After the fall of communism, NATO, WEU and CE / EU relations with the East were based on a semantic policy aimed at reducing Russia's fears. These institutions have avoided the use of the word "expansion" - a term far too offensive for Russia - replacing it with "opening" and then "enlarging". The three organizations based their enlargement policies on a rational strategy that would allow for the internal cohesion of the European institutions and their operational capacity to be maintained and ensure that there are no serious complaints from stronger neighbours (such as the Russian Federation) which could undermine the development of a European cooperative security system (Grudzinski, Ham 1999). 
Since the early 1990s, the European Community (EC) has differentiated the countries eligible for future European integration from those that are not eligible in the medium and even long term to join the European institutions. Of the former Soviet republics, only the Baltic states have been included in the first category. The aforementioned considerations have made Russia and the CIS member states (perceived as gravitating around Moscow) not to be considered eligible. Central European and Southeast European states (much later, following the adoption of the Stability Pact for Southeast Europe) have thus become the target of the enlargement policy of the European Community. Paradoxically, the Federal Republic of Yugoslavia could have been at the forefront of the list, given its relative openness towards the West since the 1970s. According to Peter Gowan, four factors, however, led to the final division, which enshrines the primacy of the Central European states in front of the Southeast European countries in the process of enlargement of the European Union: the clash between the local political tragedies and the Western shock therapy campaign launched in 1989; the impact of the German geopolitical priorities on both regions; the impact of the Yugoslav wars; the Albanian crisis (Gowan 2002, 30).

The perception of regional membership of potential candidate countries in the Union was dictated by geopolitical criteria, "Central Europe" symbolizing stability and security in Western mentality, while South Eastern Europe (especially the Western Balkans) being perceived as a source of insecurity, violence and the lack of a Western-style political culture. Over time, this difference in perception will turn as the ethnic, political and economic situation in Southeast Europe stabilizes. After the European economic intervention in Bulgaria (after the hyperinflation in 1997) and especially after the successful implementation of the Stability and Conflict Prevention FYROM pact, it became clear that the region of South-eastern Europe can also be secured and could join in the future the European and Atlantic organizations.

As the European Union matured as an international actor, developing a European (Common) Security and Defence Policy, it became clear to EU officials that the borders of European security transcend the European continent, especially in the context of the new wave of enlargement, considered rightly by political analysts as a true "enlargement boom" or "Big Bang". In this context, the EU was becoming more and more responsible for what is happening in the neighbourhood of wider Europe. 
It should be noted that if the regional policy of the European Union was marked for more than a decade by the enlargement to the East, this policy has reached its geographical and functional limits in the early 2000s. For the European Union the challenge was already identified in 2003: "H ow to exert an influence comparable to that exerted over the past decade on central and eastern Europe, but without being able to use the strict conditions for a possible accession?" (Batt, Lynch 2003 7).

The European institutions' response did not lack creativity. In fact, the year 2003 was extremely fruitful in terms of policy initiatives. It was revolutionary compared to most years of the European integration process ${ }^{1}$. Two particular documents are important in the context of this paper: "A Secure Europe in a Better World", the document presented by Javier Solana which later was adopted as the EU security strategy (EUSS), and a communication paper of the European Commission entitled "Europe's Wider Neighbourhood", which lead to the adoption of the European Neighbourhood Policy. Both were submitted to the European Council of Thesaloniki in June 2003. The documents confirmed once again the Western concerns over the Eastern European countries. The Solana document even used the findings from a Eurobarometer (No. 58/1 of Oct./Nov. 2002) to stress how the European institutions were caring about the perceptions of the European public.

The EUSS was adopted in December 2003. For a text imbued with neoliberal principles specific to the European integration process, the Solana document is filled with geopolitical reasoning. It clearly states that „our task is to promote a ring of well governed countries to the East of the European Union and on the borders of the Mediterranean with whom we can enjoy close and cooperative relations (...) It is not in our interest that enlargement should create new dividing lines in Europe. We need to extend the benefits of economic and political cooperation to our neighbours in the East while tackling political problems there" (EUSS 2003, 8). The tone is vaguely imperial, reminding about a theory developed by Robert Cooper, a very influential

${ }^{1}$ In 2003 the Convention on the Future of Europe finished the draft Treaty establishing a Constitution for Europe, the European Community presented a paper on "Wider Europe's Neighbourhood" which was the blueprint of the European Neighbourhood Policy established in 2004, and Javier Solana presented the EU's security strategy "A Secure Europe in a Better World". 
British diplomat of the Blair administration. The theory, "new liberal imperialism" was very fashionable during the years following 9/11. The strategy is over-optimistic in what concerns the ability of the European Union to model its Eastern and Southern neighbourhood into its own image.

Another surprising document is "Wider Europe's Neighbourhood: proposed new framework for relations with the EU's Eastern and Southern Neighbours" and it was drafted under the supervision of Chris Patten, another British diplomat, at that time European Commissioner for External Relations. It targeted the countries soon to become the new Eastern and Southern neighbours of the EU. The strategy concerns relations with Russia, the new independent states in the western part of the former USSR - Ukraine, Belarus, Moldova, and the South-Mediterranean countries. It agrees with the conclusions of the Copenhagen European Council (December 2002) that the enlargement is an opportunity to promote stability and prosperity beyond the borders of the Union. The document is similar in many respects to the EUSS: "Instead of trying to establish new dividing lines, deeper integration between the EU and the ring of friends will accelerate our mutual political, economic and cultural dynamism". It proposed a strategy for the next decade, starting from Chris Patten's findings: "O ver the past decade, the U nion's most successful foreign policy instrument has undeniably been the promise of EU membership. This is not sustainable. For the coming decade, we need to find new ways to export the stability, security and prosperity we have created within the enlarged EU. W e should begin by agreeing on a clearer vision for relations with our neighbours." (European Commission, 11 March 2003).

The Commission communication spoke of the development of a zone of prosperity and good neighbourliness, a "circle of friends" holding "a stake in the Internal Market" in return for demonstrating commitment to common EU values and effective implementation of reforms (political and economic). Romano Prodi, at that time President of the European Commission, expressed himself in a similar way to the one in the Solana document: "Instead of trying to establish new divisive lines, the strong integration between the EU and its circle of friends will accelerate our political dynamism, economic and cultural". Undoubtedly, the ideas suggested in the Commission's Communication and empirically grounded in the European Neighbourhood Policy are part of a new geopolitical vision of the European Union, of a new approach to regional security. 
One of the most interesting concepts developed in the years preceding the enlargement boom of the European Union was formulated by a theorist of neomedievalism: Ole Wæver. According to Wæver, the enlarged Europe has the potential to become a "a metaphorical empire", which leads us to think about multiplicity, overlapping authorities, the existence of multiple power centres. According to Wæver, the functions of this geopolitical organization would be to keep the core "intact" (this was the function of NATO's expansion waves for example), "to discipline" the regions in the proximity of the centre by using an asymmetric interdependence formula (see the conditionality for enlargement), direct intervention (an option which was supposed to become available with the emergence of the CSDP) (Wæver 1997).

Wæver approached both the European Union's and Russia's policies toward East Europe as being based on concentric circles. According to the author this is a system "that demands a lot of the EU system because ultimately it can only function if the perspective of eventual membership is kept realistic" (Wæver 1997, 336). Indeed, the EU policies toward the neighbourhood seem to justify exactly this approach specific to an empire. However, this could only have lead to a clash with Russia, the other empire using concentric circles of imperial control.

The problem with the European Union is that it was always suppose to be an entity that promotes openness and democracy. The "treaties" have always been drafted in a liberal manner, never suggesting that the EU might become a closed political system, a club of the rich. However, the enlargement "big bang" and the economic crises, followed by austerity measures, made almost impossible for the European Union to keep indefinitely the promise of enlargement for the neighbourhood countries. Yet, the promise of "a stake in the Internal Market" in exchange of political change has kept the "European dream" alive for the citizens of these countries and some members of their elite. This partly explains what happened in Ukraine since 2004 and the "A rab Spring". The EU is a victim of its own previous successes. 


\section{FROM THE ENP TO THE EASTERN PARTNERSHIP}

The European Neighbourhood Policy was established in 2004, was reviewed in 2011 due to the consequences of the Arab Spring for the Southern partners of the EU and revised again in November 2015. The policy is stated to be in line with the Global Security Strategy for the European Union's Foreign and Security Policy presented by the High Representative of the EU for Foreign Affairs and Security Policy, Federica Mogherini, in 2016. The policy is considered a "joint endeavour" between the EU represented by the European External Action Service and the EU Member States, on one side, and the 16 partner countries from Northern Africa, the Middle East and Eastern Europe.

A single look at the website of the European Neighbourhood Policy is enough to notice that the revised ENP is an instrument of the same policy of differentiation designed by the European Community and its successor, the EU, for the past decades in their relationships with the neighbours: "The key principles of the revised ENP are differentiation amongst partner countries, flexibility, joint ownership, greater involvement of the EU Member States, and shared responsibility". To add even further, it is clearly stated that the ENP is not offering the prospects of admission to the partner countries: "Through the ENP, the EU offers partner countries potential greater access to the EU's market and regulatory framework, standards and internal agencies and programmes". If enlargement policy involved the adoption of the full acquis communautaire by the candidate countries, the expectations regarding the countries forming the "Neighbourhood" are much lower (Bruns, Happ, Zichner 2016, 3). However, this does not mean that the expectations of the partner countries from their relationship with the European Union are also low. The closer it gets Europe in relationship with its neighbours, the greater is getting the power of attraction towards it. The development of civil society in the "Neighbourhood" is stimulated by the financial aid offered by the EU and the opportunities to be involved in a whole spectrum of positive interactions with European citizens, local governments, EU officials, NGOs, and companies, to name just a few number of actors having stakes in cross-border cooperation. The civil society of the neighbouring countries becomes the pro-European agent wanting democratic political change that would mirror the European political realities. Not to mention the fact that this civil society is becoming 
the best advocate for association agreements between its country and the EU. The image of "Euromaidan" movement is illustrative. What was happening in Ukraine had happened in Central Europe in 1989. The same forces driving Poland, Hungary, and Czechoslovakia towards the Big Bang enlargement of 2004 seemed to work in Kiev.

The policy provides support for the countries from the neighbourhood through a financial instrument, the European Neighbourhood Instrument (ENI) "with over E U R 15 billion for 2014-2020". It replaced the former financial instrument of the ENP, called European Neighbourhood and Partnership Instrument which had a budget of over EUR 11 billion for the period 2007-2013. Moreover, the ENPI and ENI have been designed to include previous financial instruments of the European Union regarding the neighbourhood, such as the CBC programmes (which became ENPI CBC and currently ENI CBC). The new financial instruments were building on INTERREG IIIA/TACIS CBC 2004-2006 Neighbourhood programmes (Marin, 2016: 124). While the numbers are not impressive

When it was launched, the European Neighbourhood Policy had as objectives "avoiding the emergence of new dividing lines between the enlarged EU and its neighbours and instead strengthening the prosperity, stability and security of all. It is based on the values of democracy, rule of law and respect of human rights". Following the Arab Spring and the crisis in Ukraine, the main focus is on "stabilisation of the region, in political, economic, and security related terms" (the quotes are from the website: https:/ / ec.europa.eu/neighbourhood-enlargement/neighbourhood/overview_en). The geopolitical aspects of the European Neighbourhood Policy are easily identifiable even though they may never be acknowledged by the EU officials. Clearly, the EU is not a classical empire, a fact demonstrated by the way it manages its borders. A classical empire would employ either a policy of conquest directed towards the weaker neighbours, using force to obtain submission or imposing client states, or a policy of defence, building walls to keep "barbarians" out. A symbolical empire, or a soft empire, will rather try to influence the behaviour of the neighbours so that they might begin sharing its values, principles, and norms. Unfortunately, the events taking place in the last years in Ukraine have demonstrated that while the European Union has built a new frontier policy, the ENP, to manage the relations with its Southern and Eastern neighbours, a clash with Moscow has become 
increasingly unavoidable. The Eastern Partnership, an initiative of Sweden and Poland, is for Russia a recollection of other Western policies that ended in weakening its geopolitical position (for instance the NATO Partnership). Russia seems unable to differentiate the European Union's approach from that of a Great Power seeking territorial aggrandizement. Russia still perceives the former Soviet states, and especially Ukraine, Belarus and Moldova as part of its geopolitical hinterland.

\section{THE EURASIAN GEOPOLITICAL SCHOOL OF RUSSIA}

Even though after 1991 there were several geopolitical trends supporting the integration of Russia in the Euro-Atlantic space (an example would be the ideas of Dmitri Trenin ${ }^{1}$ ), stating that Russia no longer has the same imperial vocation it use to have during the Soviet past, they were rejected by most other trends. The dominant school came to be Eurasianism, a geopolitical school developed by the Russian geo-politician Alexandr Dugin, also the leader of the Eurasia Movement. Dugin is influenced by the great yet controversial German philosopher Martin Heidegger, reputed for - among many things - his anti-technological views. Even though Dugin is maintaining, in a liberal manner, that technology is a form of progress, he also states, in Heideggerian manner, that Russia should abandon the internet, alongside some contemporary sciences like physics and chemistry (qz.com). In fact, Dugin is the supporter of a geopolitical land geo-cultural antithesis already explored for more than a century by his geopolitical predecessors: the fight between, on the one hand, the "world of the sea" (thallasocratia, which he names it Atlantis) - a decadent civilization of commerce and consumption, supporting liberal ideals, and "the world of the land" (tellurocracy) - based on presumably moral, conservative, patriarchal, autocratic

${ }^{1}$ The author of a book whose title speaks for itself: The End of Eurasia: Russia on the Border Between Geopolitics and Globalization, Carnegie Endowment for International Peace, Washington, D.C., 2001. 
ideals, closed to the traditional values. Obviously, Russia is the historical exponent of the latter.

Dugin, author of several books of geopolitics (best known for Foundations of Geopolitics), philosophy or metaphysics, promoted the idea of Russia's Eurasian expansionism. He consistently inspired himself from the works of the classical German geopolitical school and of the Anglo-Saxon school of geostrategy. His research design resembles that of Karl Haushofer. Here is a synthesis of his ideas:

First of all, Dugin outlines the future directions of action for Russia, these being:

- Inside, Russia should establish, based on a reform, a multi-ethnic and multi-religious state, spreading Panslavism and Panorthodoxism;

- Outside, Russia must counterbalance the Anglo-Saxon maritime powers promoting alliances with Germany and Japan;

The Russian geopolitician supports three special projects drawn accordingly to Russia's geopolitical aims:

$>$ Pan-European: aiming to the establishment of a European empire built aroung Germany and it's concept of Mitteleuropa $(!)$

> Pan-Islamic: a Muslim empire in Central Asia built around Iran

$>$ Pan-Asiatic: an empire in the Pacific region, organized around Japan.

Russia will never be a part of these empires since it is already a great empire and it has the vocation of dominating the others, according to Dugin.

Dugin's geopolitical projects are much more related to the geopolitical imagination than to possible realities. There are many factors that prevent the materialization of the Eurasian project of Dugin, however seductive would be for the contemporary Russian political elite.

Even the Russian geopolitical admits that the Eurasian scenario is not certain, since it is not assumed by the entire Russian political and intellectual elite. Russia is in fact the prisoner of a "protracted geopolitical crisis", according to Dugin. He emphasises that "the most dispassionate and impartial analysis of Russia's geopolitics shows that today's position is a pathology, a deviation from its natural, undeniable historical trajectory" (Dugin 2015, 96). 
Among the harsh conclusions that Dugin is making in his geopolitical manifesto of 2015 the following one cautions us: "Therefore, geopolitically, it is unfounded and empty to hope that Russia will be able to preserve itself in the reduced and regional form in which it now exists, after repudiating mobilization, a new round of expansion, and any participation in world-historical processes on behalf of the civilization of Land (expressed today in the principle of multipolarity" (Dugin 2015, 97). Dugin's work remains critical even towards the administration which he clearly influenced so far: Putin Administration.

\section{FROM THE EURASIAN THEORY TO THE GEOPOLITICAL PRACTISE OF PUTIN ADMINISTRATION}

It is probably an exaggeration to state that the Eurasian project of Dugin dominates the foreign and security policy agenda of the Russian Federation, though there are several aspects seeming to confirm the influence of Dugin's ideas on Putin Administration, among which the Eurasian Union and the occupation of Crimea. Even the important review of international relations Foreign A ffairs headlined in March 2014: "Putin's Brain : A lexander Dugin and the Philosophy Behind Putin's Invasion of Crimea". In fact, in 2015 the US and Canada put him on the list of sanctioned individuals as a result of his involvement in the Ukrainian crisis.

However, it would be very hard to suggest that the Kremlin's leaders do not know very well the facts: Russia is in a deep demographic decline and its economic growth, no matter how spectacular it was so far, it brings it to the 10th place worldwide, far behind some geopolitical actors of global importance such as the EU, US and China.

Currently, it seems evident that geopolitics is used as an instrument of power for Vladimir Putin's Russia, but more than that, as an instrument of propaganda, enjoying success among the Russian population, and some right-wing elements from Europe and the US. However, in the light of Russian history, pragmatism is the dominant word. Russia will always seek to obtain a much more important place at the negotiation table regarding global politics, but this place will much 
depend on the international recognition and in the lack of reaction by the other power centres towards the major claims of Russia. Russia will not risk a world war, the nuclear deadlock remaining constant, even though an author such as Alexander Dugin keeps preaching a "war of civilizations" with a clear finality. Russia's objective remains to accumulate more international prestige and in its geopolitical imaginary this cannot be obtained unless it will be treated as equal partner by the United States of America.

Regarding the European Union and its "neighbourhood policy" Russia seems to be unable to judge the EU as a new type of political entity that even defies the habits of a traditional Great Power. Even though the EU is lacking a common army that could pose a threat to Russian borders, the Kremlin is very reactive against any European enlargement towards its "Near Abroad", probably because it makes no clear difference between the EU and NATO, the US, or the "West". The old Russian school of geopolitical thinking is still involved in the political establishment. This probably explains why Russia implemented an alternative plan in Ukraine after the demise of Viktor Janukovic, namely the annexation of Crimea and the destabilization of the Donetsk region.

Ukraine was the second largest Soviet republic in terms of population. The Russian geopolitical imagination is still haunted by the loss of an empire that rivalled only with the United States. The reaction of Moscow to the presumed loss of Ukraine reminded also that in 2008 Georgia wanted to join NATO.

\section{CONCLUSIONS}

The European Union and Russia seem to be on a collision course in geopolitical and geo-economic terms. It is a clash between a soft power and a hard power. However, both actors are not currently in their best seats. They are both facing a very radicalized environment, prone to revolutionary change. This is especially true for the countries of North Africa and the Middle East, but the Euromaidan showed that this potential exists also for the countries of Eastern Europe. Geopolitical approaches may come to be only illusions of political elites that are losing the control over their civil societies. The ENP may not stop citizens' desire 
to get closer to an area of stability and prosperity such as the European Union. Classical geopolitical approaches may fail to prevent Eastern civil societies to live the dream of uniting with Europe as an exponent of Western civilization.

\section{REFERENCES}

- Barbashin, Anton and Thoburn, Hannah, "Putin's Brain: Alexander Dugin and the Philosophy Behind Putin's Invasion of Crimea". Foreign Affairs, March 2014.

- $\quad$ Batt, Judy; Lynch, Dov et al., "Partenaires et voisins: une PESC pour une Europe élargie", Cahiers de Chaillot, nr. 64, EU-ISS, September 2003.

- $\quad$ Bruns, Bettina; Happ, Dorit; Zichner, Helga (eds.), European N eighborhood Policy: Geopolitics between integration and security, London: Palgrave Macmillan, 2016.

- $\quad$ Cohen, Saul B., Geopolitics: The Geography of International Relations, 3rd edition, Lanham: Rowman\&Littlefield, 2015.

- Dugin, Alexander, Last War of the World Island: The Geopolitics of Contemporary Russia, London: Arktos, 2015.

- $\quad$ EEAS, „European Security Strategy - A Secure Europe in a Better World", Brussels, 12 December $2003 . \quad$ Website:

https://europa.eu/globalstrategy/en/european-security-strategy-secureeurope-better-world

- $\quad$ European Commission, “Wider Europe's Neighbourhood: proposed new framework for relations with the EU's Eastern and Southern Neighbours", Brussels, 11 ${ }^{\text {th }}$ March 2003. Internet: http:/ / europa.eu/rapid/press-release_IP-03358_en.htm

- European Commission: https://ec.europa.eu/neighbourhoodenlargement/neighbourhood/overview_en

- European Council, "A Secure Europe in a Better World: European Security Strategy", Brussels, 12 December 2003. Internet: http:/ / www.envirosecurity.org/ges/ESS12Dec2003.pdf

- $\quad$ Gowan, Peter, "The EU and Eastern Europe: Diversity without Unity?", in Mary Farrell, Stefano Fella, Michael Newman, European Integration in the 21st Century. U nity in Diversity?, SAGE Publications, Londra, Thousand Oaks, New Delhi, 2002, pp. 29-30. 
- $\quad$ Grabbe, Heather, "The Sharp Edges of Europe: Security Implications of Extending EU Border Policies Eastwards", EU-ISS O ccasional Paper 13, Paris, March 2000.

- $\quad$ Grudzinski, Przemyslaw, Ham, Peter van, A Critical A pproach to European Security: Identity and Institutions, London and New York: Pinter, 1999.

- $\quad$ Kaplan, Robert D., The Revenge of Geography: W hat the map tells us about the coming conflicts and the battle against fate, New York: Random House, 2012.

- Kelly, Phill, Classical Geopolitics: A New Analytical Model, Stanford: Stanford University Press, 2016.

- Marin, Anais, "Of barriers, breaches and bridges: cross-border ecoturism and the prospect of horizontal governance acting as bridge in the Belarus-EU Neighborhood Relations", in Liikanen, I., Scott, J.W., Sotkasiira, T., The EU's Eastern N eighborhood: M igration, Borders and Regional Stability, London and New York: Routledge, 2016, pp.115-134.

- Qz.com, “The philosopher known as "Putin's brain" is a big fan of Trump", https://qz.com/871975/aleksandr-dugin-putins-favorite-philosopheris-a-big-fan-of-donald-trump/

- Toal, Gerard (Ó Tuathail, Gearóid in Irish), Critical Geopolitics: The Politics of W ritting Global Space, London: Routledge, 1996.

- $\quad$ Trenin, Dmitri, The End of Eurasia: Russia on the Border Between Geopolitics and Globalization, , Washington: Carnegie Endowment for International Peace, 2001.

- Tunander, Ola, "Post-Cold War Europe: Synthesis of a bipolar friend-foe structure and a hierarchic Cosmos-Chaos Structure?", in Tunander, O., Baev, P., Einagel, V. I. (eds.), Geopolitics in Post-W all Europe: Security, Territory and Identity, Oslo: SAGE Publications, 1997.

- Wæver, Ole, “After Neo-Medievalism: Imperial Metaphors for European Security", in Burgess, Peter (ed.), Cultural Politics and Political Culture in Postmodern Europe, Amsterdam, Atlanta: Rodopi, 1997, pp. 321-366.

- Wæver, Ole, “Imperial Metaphors: Emerging European Analogies to PreNation-State Imperial Systems", in Tunander, O., Baev, P., Einagel, V. I. (eds.), Geopolitics in Post-Wall Europe: Security, Territory and Identity, Oslo: SAGE Publications, 1997, pp. 66-72. 


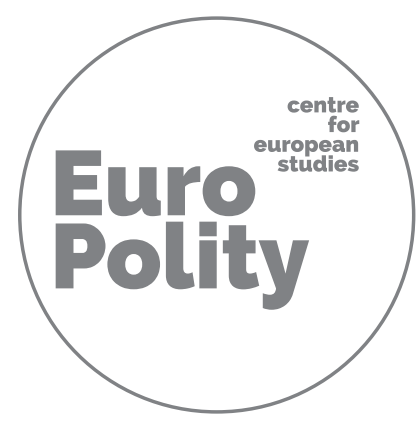




\title{
EUROPEAN UNION SUPPORT AND TRANSITIONAL JUSTICE PROCESSES IN KOSOVO
}

\author{
Remzije Istrefi \\ Professor Assistant \\ Faculty of Law, University of Prishtina \\ Prishtina/Kosovo \\ remzie.istrefi@uni-p.edu
}

\begin{abstract}
The legacy of systematic human rights violations committed during 1999 violent conflict and the previous repressive rule still impact the everyday life of Kosovo citizens. That is why transitional justice processes are a necessary component in Kosovo's state building efforts. With the end of the 1999 conflict, Kosovo has been administered by the United Nations Mission in Kosovo (UNMIK) and also supported by European Union (EU) presences: the EU Special Representative in Kosovo, and European Union Rule of Law Mission known as EULEX. In the course of implementation of their mandates transitional justice processes were not a priority for UNMIK and EU presences. With the signing of the Stabilization and Association Agreement (SAA) the EU made transitional justice part of the Kosovo accession demands. In December 2015, the Government of Kosovo approved its National Action Plan for the Implementation of the Stabilization and Association Agreement (NAPISAA). The General Principles of the SAA, included within the NAPISAA oblige Kosovo Government to approve a National Transitional Justice Strategy. This paper analyses EU peace and institutionbuilding support and their impact in transitional justice processes in Kosovo. Through analysing the mandate and actions on the ground it draws conclusions if $\mathrm{EU}$ is an active participant in transitional justice process in Kosovo or transitional justice policies are promoted by EU only as part of its enlargement
\end{abstract}


strategy. Finally, the paper gives recommendations as a basis for future elaboration of an EU approach to transitional justice.

\section{Keywords}

EU, EULEX, Human rights, Transitional Justice, UNMIK.

\section{INTRODUCTION}

Dealing with the legacy of mass atrocities in a period of change after violent conflict and/or regime change is a challenging and complex task. Transitional justice has emerged as a possible response to the difficult dilemmas that the transformations generate. It is a way to articulate the different processes considered necessary to help a society move from a period of repression and/or conflict to one in which human rights, democracy and the rule of law can prevail (Institute for Democracy and Conflict Resolution 2011, 10). According to the most commonly used definition first published in the United Nations (UN) SecretaryGeneral's report on the rule of law and transitional justice in conflict and postconflict societies in 2004 transitional justice can be described as "the full range of processes and mechanisms associated with a society's attempts to come to terms with a legacy of largescale past abuses, in order to ensure accountability, serve justice and achieve reconciliation" (Report of the UN Secretary General 2004, 2). These may "include both judicial and non-judicial mechanisms, with differing levels of international involvement (or none at all) and individual prosecutions, reparations, truth-seeking, institutional reform, vetting and dismissals, or a combination thereof" (Report of the UN Secretary General 2004, 4). This definition incorporates: the right to know, right to justice, right to non-recurrence and right to reparation, the four principles which are widely acknowledged to constitute the core elements of transitional justice (Sisson 2001, 2). Experience has shown that the most successful transitional justice processes are those initiated by the local populations and which were characterized by the local ownership and allinclusive consultation processes. The consultation and transparent activities of the Truth and Reconciliation Commission in post apartheid South Africa in 1999s 
(Tietel 2003), the overall engagement of the victims and their families in discovering the whereabouts of the disappeared persons in Argentina by the Argentine National Commission on the Disappeared (Hayner 1994, Hayner 2001), and inclusion of women and youth in consultation and reconciliation process in Northern Ireland (Ward 2005) are among many models to be considered by the societies undergoing transitional justice processes. In the past decades, the international and regional organizations and their missions play an influential and catalytic role in facilitating justice and reconciling divided societies through the post conflict peace building efforts. International organizations not only provide an intermediary role between the former enemies, but have become an effective participant in designing and undertaking activities that form part of the transitional justice mechanism in some cases aiming reconciliation among them. The UN SG Kofi Annan, acknowledged that there had been an increased focus by the UN on questions of justice, transitional justice, and the rule of law in conflict and post-conflict societies (UN SecretaryGeneral 2004, 4). He noted that direct UN involvement in post-conflict societies has been characterized by the importation of transitional justice apparatus, for example, in Kosovo and Timor-Leste, where the UN has been directly involved in the administration of judiciaries, police, and prison services. The normative foundation for the work of the UN in advancing transitional justice is the Charter of the United Nations (UN Charter of the United Nations 1945), and the main pillars of the modern international legal system: international human rights law, international humanitarian law, international criminal law, and international refugee law. Various UN instruments guarantee the rights and duties related to: the right to justice ( UN GA International Covenant on Civil and Political Rights 1966, Article 2, UN GA Convention against Torture and Other Cruel, Inhuman Degrading Treatment or Punishment 1984, Articles 4, 5, 7 and 12, UN GA International Convention for the Protection of All Persons from Enforced Disappearance 2006, Articles 3, 6, 7 and 11); the right to truth (UN GA International Covenant on Civil and Political Rights 1966, Article 2, UN GA International Convention for the Protection of All Persons from Enforced Disappearance 2006, Article 24): the right to reparations (UN GA Universal Declaration of Human Rights 1948, Article 8, UN GA International Covenant on 
Civil and Political Rights 1966, Article 2, UN GA International Convention on the Elimination of All Forms of Racial Discrimination 1965, Article 6, UN GA Convention against Torture and Other Cruel, Inhuman, Degrading Treatment or Punishment 1984, Article 6, UN GA International Convention for the Protection of All Persons from Enforced Disappearance 2006, Article 24, the UN GA Convention on the Rights of the Child 1989, Article 39), and the guarantees of non-recurrence of violations (UN GA International Covenant on Civil and Political Rights 1966, Article 2, UN GA Convention against Torture and Other Cruel, Inhuman, Degrading Treatment or Punishment 1984, Article 2, UN GA International Convention for the Protection of All Persons from Enforced Disappearance 2006, Article 23). Additionally, transitional codes, guidelines, and rule of law policy tools have been devised. The Office of the UN High Commissioner for Human Rights (OHCHR) released in 2006 the Rule-of law Tools for Post conflict States (OHCHR, Rule-of law Tools for Post-conflict States 2006). The UN Secretary General provides in his Guidance Note the guiding principles and framework for a United Nations approach to transitional justice processes and mechanisms (United Nations Guidance Note of the SecretaryGeneral 2010).

Simultaneously, the European Union has increased its involvement in crisis management and through its peace- and institution building programmes has become one of the major contributors in post conflict territories. The Treaty on European Union, provides that the "The U nion's aim is to promote peace, its values and the wellbeing of its peoples" (EU Treaty Establishing the European Community 1957, Article 3.1). The EU is committed to promoting peace, to the protection of the EU's rights and to the strict observance and the development of international law (EU Treaty Establishing the European Community 1957, Article 3. paras. $1 \& 5)$.

The EU founding documents (Treaty of the European Union 1957, Treaty of Maastricht 1992) do not provide for specific definition (Davlis 2014) and reference on Transitional Justice. However, several articles provide for a framework to accommodate transitional justice initiatives. Article 177.2 of the Maastricht Treaty specifies that European policy in the area of development cooperation will contribute to the general objective of development and 
consolidation of democracy and the rule of law, as well as respect for human rights and fundamental liberties (European Union Treaty of Maastricht 1992, Article 177.2). Similarly, Article 11.1 of the European Union Treaty, which is the legal basis for Common Foreign and Security Policy (CFSP), establishes democracy, the rule of law and respect for human rights and fundamental liberties as priorities (European Union Treaty Establishing the European Community 1957, Article 11.1). Article 17.2 of the European Union Treaty provides for CFSP tasks and lists among others the "humanitarian and rescue tasks, peacekeeping tasks, and tasks of combat forces in crisis management, including peacemaking" (European Union Treaty Establishing the European Community 1957, Article 17.2). All these articles provide for the EUs undertakings towards states in crisis or in the territories that are undergoing the process of reestablishing peace after conflicts. At the level of EU legislation, explicit reference is made regarding the aspects of Transitional Justice in the Regulation no. 1889/2006 of the European Parliament and the Council, from December 20, 2006 which established a financial instrument for the promotion of democracy and human rights worldwide (Regulation no. 1889/2006 amended in 2014 (Regulation (EU) No 230/2014)). In Article 2, of the Regulation no. 1889/2006 through the financial instrument for the promotion of global democracy and human rights programme, the EU support seeks to: ii) "strengthen the rule of law, promoting the independence of the judiciary, encouraging and evaluating legal and institutional reforms, and promoting access to justice; iii) promote and strengthen the International Criminal Court, ad-hoc international criminal tribunals and the processes of transitional justice and truth and reconciliation mechanisms; iv) support reforms to achieve effective and transparent democratic accountability" The Instrument for Stability can support financially "international criminal tribunals and ad-hoc national tribunals, truth and reconciliation commissions, and mechanisms for the legal settlement of human rights claims and the assertion and adjudication of property rights, established in accordance with international human rights and rule of law standards." (Regulation (EU) No 230/2014 of the European Parliament and of the Council 2014: section (e)). It also provides "support for civilian measures related to the demobilisation and reintegration of former combatants into civil society, and where appropriate their repatriation, as well as measures to address the situation of child soldiers and female 
combatants" (Regulation (EU) No 230/2014 of the European Parliament and of the Council, 2014:section (g)). The inclusion of Demobilization, Disarmament and Reintegration (DDR) programmes is noteworthy, since is recognized as one of the necessary measures to be undertaken by societies in achieving non recurrence as a part of Transitional Justice itself.

The European Instrument for Democracy and Human Rights (EIDHR) is the main financial instrument that covers the period 2014-2020 with a total financial envelope of EUR 1,332,752,000. Under the new Regulation 235/2014 of the European Parliament and the Council, which replaces Regulation 1889/2006 (2007-2013), the EIDHR's budget has been increased with the aim to provide wider support for civil society and increase the EU's capacity to react promptly to human rights emergencies (European Commission, MEMO/13/1134. 8).

Transitional justice as an aspect to be carried out is found also in EU policy strands, in declarations, reports and consensus documents. Transitional Justice is envisaged in the Common Foreign \& Security Policy (CFSP), in the European Security and Defence Policy (ESDP) and the Cooperation Policy which all call for the promotion of democracy and human rights throughout the world (European Security Strategy, 2003) The main EU body for defining the CFSP's areas of action including the transitional justice actions is the EU Council. On 16 November 2015 the EU Council has adopted conclusions on the EU's support to transitional justice (EU's support to transitional justice - Council conclusions, 2015). With this document the EU Council reaffirmed the EU's intention to play an active and consistent role in its engagement with partner countries and international and regional organizations in support of transitional justice processes. The Council also adopted the EU's policy framework on support to transitional justice (The EU's Policy Framework on support to transitional justice, 2015). This document provides a framework for EU support to transitional justice mechanisms and processes and enhance the EU's ability to play a more active and consistent role, both in its engagement with partner countries and with international and regional organizations. It builds upon and complements the EU's existing strong policy in support of the International Criminal Court and takes account of the UN's framework and activities on transitional justice. 
Despite all the legal framework accommodating transitional justice aspects, the political commitments, policies and strategies to date the key question facing the international organizations through their peace building activities on the ground is how to deal with the painful legacy of past violence, while at the same time maintain the fragile peace and simultaneously implement their missions peace and state building mandates. The factual situation on the ground after the deployment of international presences in Kosovo exemplify this dichotomy in the international peace building efforts. In particular in the first years of international administration of Kosovo UNMIK (and KFOR) assumed almost all state functions over the territory. As a result of the conflict UNMIK was faced with destruction everywhere, including family homes, schools and hospitals. Roads were mined; bridges were destroyed; and radio and television were off the air. Mass killings and gross human rights violations by the Serbian military and paramilitary forces towards the Albanian populations; the unresolved issue of missing persons led to the interethnic conflict and incidents which at least twice in the life time of administration by UNMIK have risked the overall peace and security and with it have questioned the presence of the UNMIK and KFOR in Kosovo (Amnesty International 2000; Amnesty International 2004a Amnesty International 2004b, Human Rights Watch 2004; International Crises Group 2004). That is why through ought the exercise of their mandate UNMIK and latter EU presences directed their activities towards maintaining peace and security and institutional building and less dealt with the societal issues such are transitional justice process.

\section{TRANSITIONAL JUSTICE PROCESSES INTERNATIONAL ADMINISTRATION AND STEBUILDING PROCESSES IN KOSOVO}

There are several factors that should be taken into account when analysing transitional justice processes in Kosovo and the role of international actors. The NATO airstrikes over Serbia that lasted 78 days were concluded with the signing 
of the Military Technical Agreement (Military Technical Agreement 1999) that paved the way for instituting the civilian mission under the UN auspices known as UNMIK (UN SC Resolution 1244 1999). UNMIK's mandate was extensive and unprecedented both in scope and structural complexity. As authorized by the UNSC Resolution (UNSCR) 1244 of 10 June 1999, UNMIK's mandate included establishing an interim civilian administration including police, promoting the establishment of substantial autonomy and self-government in Kosovo, creating a democratic political atmosphere respectful of human rights, repatriating over one million refugees, supporting the reconstruction of infrastructure and the economic system, maintaining civil law and order, promoting human rights, and ensuring safe return of refugees and displaced persons to their homes. UNMIK was responsible for coordinating the reconstruction efforts of all international agencies operating in Kosovo. The OSCE was in charge of the Democratization and Institution Building (pillar III), and the EU was responsible for the Reconstruction and Economic Development pillar (pillar IV). Placed outside of the pillar structure, NATO's Kosovo Force (KFOR) mission was and continues to be responsible for providing a secure environment in Kosovo. The modalities for establishing conditions through which the past human rights abuses will not be repeated and ensuring accountability for past atrocities have been exemplified by the terms of peace settlements and political transitions which also paved the way for EU's extensive presence in Kosovo. These modalities relate to two major processes: development of a set of implementation standards for the Provisional Institutions for Self-Government (PISG), ${ }^{1}$ and the Final status processes. ${ }^{1}$ After

1 In December 2003, UNMIK published the Kosovo Standards Implementation Plan (Implementation Plan), which was subsequently endorsed by the Security Council. The Implementation Plan laid out the indicators that would establish "the basis for any review in mid-2005 to begin consideration of Kosovo's final status. The set of implementation standards for the PISG that involved establishment of a range of democratic governance principles i.e. a comprehensive legal framework covering political party operation and finances to be adopted and enforced...; all communities are proportionately represented at all levels of the PISG, in accordance with applicable legislation; the PISG and local municipal government decide and enact legislation in an 
the evaluation of the achievement of Standards before Status, in 2005, the process of defining the future status of Kosovo was initiated by the UN Security Council. The UN Secretary General authorized Martti Ahtisaari as the Special Envoy to develop the Comprehensive Proposal for the Kosovo Status Settlement (Comprehensive Proposal for the Kosovo Status Settlement 2007). The Status Settlement Proposal(Ahtisari plan) involved the internationally supervised independence of Kosovo by the international community and the EU. The EU specific role in Kosovo was reflected in the establishment of an International Civilian Office (ICO) and an EU mission in the rule of law area (EULEX) under the European Security and Defence Policy (ESDP). The Guiding principles for the envisaged international/EU presence in Kosovo was based on understanding that after the status settlement, the governance of Kosovo will be in the hands of its people and their elected authorities. Therefore, the activities to be undertaken by the international community and the EU imply a major shift from international governance towards Kosovo governance. In the Status settlement proposal (Ahtisari plan) the transitional justice has been deemed a constitutional

open, accountable and democratic manner...; PISG and Municipalities ensure the availability of basic public services such as health care, utilities and education, without discrimination to all communities in Kosovo...; all communities are fully and fairly represented amongst judges, prosecutors and in the Kosovo Police Service (KPS) and Kosovo Corrections Service (KCS)...; [and],there is effective action to eliminate violence against women and children, trafficking and other forms of exploitation, including preventative education and provision of legal and social services to victims". See generally Kosovo Standards Implementation Plan, Executive Summary, UNMIK, 31 March 2004.

${ }^{1}$ After more than six years of international administration by UNMIK in Kosovo, the international community agreed to open the issue of the future political status of Kosovo. In essence, the Contact Group, an informal grouping of six countries (USA, Russia, United Kingdom, Germany, France and Italy) in the second part of 2005, agreed to open the issue of the future political status of Kosovo. Subsequent to this, on 14 November 2005 the UN Secretary General appointed Marti Ahtisaari as the Special Envoy of the Secretary General of the United Nations for the process regarding Kosovo's future status (UNOSEK, 2007a). See generally: A comprehensive review of the situation in Kosovo, Eide Report (2005), S/2005/635. 
obligation. Article 2.5 of the Status settlement proposal (Ahtisari plan) states that "Kosovo Government shall fully promote reconciliation among communities and shall establish a comprehensive gender based sensitive approach for dealing with its past" (Comprehensive Proposal For the Kosovo Status Settlement 2007, Article 2.5). The main activities of $1 \mathrm{CO}$, in implementing the Status settlement proposal (Ahtisari plan), before disbanding in September 2012, were cooperation with the Government and the Kosovo Assembly in establishing an inter-ministerial working group on dealing with the past and also support in drafting the regulation on that working group (Rafaeli 2012). The ICO also intervened and proposed amendments to draft texts of the Laws on Witness Protection, War crimes prosecution, Political Prisoners, War Veterans, and Victim Compensation with particular interest in victims of sexual violence (Bernhardt and Ferizi 2011). ICO organized a series of consultation workshops with key officials from most ministries of the Kosovo government and CSOs as well (Muižnieks 2012), and it has publicly announced their approval of regional truth commission in the former Yugoslavia, known as RECOM initiative (De Leillo 2013).

With the end of supervised independence, the key document for undertaking the transitional justice processes is the Constitution of the Republic of Kosovo that came into force on the $15^{\text {th }}$ of June 2008 (Constitution of the Republic of Kosovo, 2008). Under its provisions on state responsibilities, it calls for "a spirit of tolerance, dialogue, and support reconciliation among communities" (Constitution of the Republic of Kosovo 2008, Article 58). Kosovo Constitution guarantees international human rights standards (Constitution of the Republic of Kosovo 2008, Chapter II), it secures a central role of international human rights agreements (Constitution of the Republic of Kosovo 2008, Article 22) and also contains extended protections for the rights of minority communities (Constitution of the Republic of Kosovo 2008, Chapter III). These constitutional values form the very essence of the constitutional influence on transitional justice processes in Kosovo. The human rights guarantees in the Constitution establish the societal and political conditions for national reconciliation, through guaranteeing societal and political processes to function and develop through elimination of previous patterns that have caused the conflict.The Constitution of Kosovo protects and promotes the rights and interests of communities and their 
members living in Kosovo. It states that "Kosovo is a multi-ethnic society consisting of Albanian and other Communities, governed democratically with full respect for the rule of law through its legislative, executive and judicial institutions, and guarantees full and effective equality for all its citizens" (Constitution of the Republic of Kosovo 2008, Article 3). The Constitution defines that "the official languages in Kosovo are Albanian and Serbian (Constitution of the Republic of Kosovo 2008, Article 5.1). Turkish, Bosnian and Roma languages can have the status of official languages at the municipal level or will be in official use at all levels as provided by law" (Constitution of the Republic of Kosovo 2008, Article 5.2). The Constitution also ensures equitable representation in public institutions, requires the representation of communities through several specific posts at the municipal level, enshrines the right of communities to "freely express, foster and develop their identity and community attributes" and establishes obligations of the state to ensure "full and effective equality among members of communities" (Constitution of the Republic of Kosovo 2008, Article 61). Finally, Chapter III also foresees the establishment of a Consultative Council for Communities, consisting of, amongst others, representatives of communities, with the mandate to afford communities the opportunity to comment at an early stage on legislative or policy initiatives, and to seek to have their views incorporated in relevant projects and programs.

The Constitution also protects the rights of communities in the legislative process. Out of an Assembly of 120 seats, it guarantees 20 seats for parties representing minority communities, with a specific number of seats assigned to the different communities (Constitution of the Republic of Kosovo, 2008: Article 64) Additionally, the Constitution requires the creation of the Assembly Committee on Rights and Interests of Communities and ensures that legislation covering certain issues will be considered legislation of vital interest, which requires a double majority for their adoption, amendment or repeal, both a majority of the entire Assembly and a majority of the deputies holding seats guaranteed for communities (Constitution of the Republic of Kosovo 2008, Article 81). Finally, any amendment of the Constitution itself requires a double two thirds majority, of both the entire Assembly and the deputies holding seats guaranteed for communities (Constitution of the Republic of Kosovo 2008, Article 144). 


\section{EUROPEAN UNION PEACEBUILDING EFFORTS AND TRANSITIONAL JUSTICE PROCESS IN KOSOVO}

With the declaration of Kosovo's independence the Kosovo's authorities took the overall governance of public institutions. As such in June 2008, the UN SecretaryGeneral announced the reconfiguration of the structure and profile of the international civil presence in Kosovo. As such, the European Union Rule of Law Mission in Kosovo (EULEX) was to "assume responsibilities in the areas of policing, justice and customs, under the overall authority of the U nited N ations, headed by [. . .] [the Special Representative of the Secretary-General], and in accordance with resolution 1244 (1999)" (European Union Rule of Law Mission EULEX). The relationship between UNMIK and EULEX has been notable with regard to the issue of the transfer of power and files from UNMIK to EULEX in the field of the rule of law. This process of transfer from UNMIK to EULEX took place on the initial operational day of EULEX 9 December 2008.According to the EULEX report delivered to the UN on 17 June 2009, the handover of case files from UNMIK to EULEX was successfully completed (EULEX report to the UN 2009). Moreover, this report indicated that EULEX conducted initial investigations for some of the priority cases (files) transferred from UNMIK. It is to be noted here that Kosovo judicial system since its establishment by UNMIK has been characterised by its unique hybrid nature. While under UNMIK administration Kosovo courts operated under UN SC Resolution 1244 and comprised international and local judges (Cerone and Baldwin 2004). After the declaration of independence UNMIK courts have been dissolved and replaced by Kosovo courts supplemented by EU mandated judicial presence the EULEX. The UNMIK war crimes jurisdiction has been transferred to EULEX judges and prosecutors. According to Bernard Borchard, the EULEX Head of Mission, EULEX inherited 1200 war crimes cases from UNMIK. From 12000 war crime cases 500 cases are closed or dismissed (due to lack of evidence). There are 300 cases pending with Kosovo and EULEX prosecutors within SPRK. There are 300 cases pending with The War Crimes Investigative Unit of KP and EULEX. More than 800,000 pages 
have been reviewed related to these cases. 51 new war crimes cases have been initiated, including the first-ever investigations into cases where acts of sexual violence or rape have been assessed as war crimes. Kosovo and EULEX prosecutors are currently investigating 100 war-crimes cases and there are 5 ongoing war-crimes trials. In total, and under the Kosovo legal framework, 15 war crimes cases have been adjudicated. Just under half of these (7) involved defendants of Serb ethnicity and just over half of these (8) involved defendants of Albanian ethnicity. There are additional 13 arrest warrants against Serbian defendants, but they are outside the Kosovo legal jurisdiction. There are 216 active cases on Missing Persons. Through field operations and forensic assessment, EULEX together with Kosovo experts are working that the remains of over 330 individuals are returned to their families (European Union External Action, EULEX and war Crimes, 2014). At the time of this writing EULEX is still in the process of handing over the cases to the local judiciary. It is expected that this process will be over before 2018 with the closure of the EULEX mandates (Council Decision (CFSP) 2016/947 2016).

Despite all the efforts, the success of EULEX is limited; in particular little progress has been reported in investigations and prosecutions which relate to the abductions of Serbs and other minorities (Amnesty International, 2012). EULEX did not demonstrate that the fight against impunity is one of its priorities, and it did not present a coherent strategy for fighting impunity (Amnesty International 2012). Several reasons have been mentioned by human rights NGOs (Amnesty International, 2012) and scholars (De Wet 2009, Rafaeli 2012, J.P. Jacque 2015) for affecting the EULEX's successes in combating impunity -lack of political will, insufficient resources allocated to handle cases, short term appointment of mission personnel without relevant experience, insufficient witness protection, that felt within the EULEX mandate, lack of cooperation with local stakeholders, lack of protection of local prosecutors and members of judiciary, weak domestic justice system, and allegations of corruption within the senior EULEX staff (The Guardian 2014). Lately, it is interesting to evidence that the Kosovo citizens have started to initiate cases against EULEX in front of the Human Rights Panel alleging violation of their rights as a consequence of the conflict and its aftermath. The Case no. 2014-34, Rejhane Sadiku-Syla against EULEX exemplifies 
this development. The complainant in this case, is related to the disappearance of the father of the complainant, who disappeared from his residence in northern Mitrovica in the course of an attack by a group of armed persons, believed to be of Serb ethnicity on 7 December 2000. The complainant submitted that EULEX Kosovo had violated her rights as guaranteed by Articles 2 and 3 of the European Convention (Council of Europe European Convention 1950) under their procedural limb. In particular, it was submitted that EULEX Prosecutors failed to initiate an investigation in accordance with Kosovo law and the mandate of EULEX Kosovo, that EULEX unduly delayed the investigative process and that in the referral of the case to Kosovo prosecutors, had neglected the seriousness of the case, the geographical location of the crime, (northern Mitrovica), the war crime character of the case and the fact that the incident had most likely been motivated by ethnic hatred. Having regard to the circumstances of the case in their entirety, the Panel found that the investigative efforts of EULEX Kosovo, in respect of the disappearance of the father of the complainant, were inadequate. These investigative shortcomings thereby resulted in violations of the rights of the complainant as guaranteed by Articles 2 and 3 of the European Convention in respect of the right to life and the prohibition of torture in their procedural limb, and those rights protected by Article 13, the right to an effective remedy, in conjunction with Article 2 of the European Convention. Given these findings, the Panel considered that it was unnecessary to further review the case under Article 8 of the European Convention. Indeed this case and others to come will further contribute to the development of the standards for protection of human rights of individuals under international peace building missions.

Generally "institutions of the international community have perceived criminal prosecution as the most forceful tool in transitional justice in Kosovo" (Philippe Kirshc Institute 2017). The EUs involvement in the establishment of the Special Court for Kosovo supports further this perception. The Special Rapportueer for the Parliamentary Assembly of the Council of Europe, Marty submitted a report entitled 'Inhuman treatment of people and illicit trafficking in human organs in Kosovo', on 12 December 2010 to the Committee on Legal Affairs and Human Rights (Committee on Legal Affairs and Human Rights 2010). The report was attached to a resolution by the Parliamentary Assembly of the Council of Europe 
calling on the EU to allocate resources through EULEX to investigate the allegations and protect witnesses (Assemblée Parlementaire Du Conseil De L'Europe Resolution 1782 2011). EULEX responded by establishing the Special Investigative Task Force, a special prosecutorial unit based in Brussels to pursue the investigation. Based on the first investigations, the EU and the US supported the idea of establishing a special court seated outside Kosovo and operating as an international court. The EU tied the court to Kosovo's European integration agenda and officially requested Kosovo to accept the establishment of a hybrid international court to investigate Dick Marty's allegations (Statement by Samuel Žbogar, Head of the EU Office in Kosovo and EU Special Representative 2014). On 24 April 2014, the Assembly of Kosovo ratified the exchange of letters between the Kosovo President Atifete Jahjaga and Baroness Ashton on the extension of the EULEX mandate. It also provided for reallocation of the sensitive judicial cases arising out of the investigation led by the Special Investigative Task Force to address the allegations of the 2011 Council of Europe Parliamentary Assembly report of the Special Rapporteur Dick Marty. Amendments to key legislation, including the Constitution, were adopted by the legislature to establish the Special Court and its prosecution office (BBC News, Kosovo parliament approves special war crimes court 2015). The Special Court comprising of the Special Chamber and Prosecutors Office will be part of the Kosovo judicial system and will be composed of international judges and prosecutors; it will operate both in Kosovo and at The Hague, in the Netherlands. The witnesses and the accused will be sent to The Hague to avoid witness intimidation and ensure a credible judicial process. The EU both drafted and sponsored the law on the establishment of the Special Court for Kosovo (Law No.05/L-053 On Specialist Chambers and Specialist Prosecutor's Office 2015) has been adopted on 3 august 2015. The Special Court will be a parallel system of courts composed of four judicial instances (three regular plus the constitutional one) external to the current judicial system of the Republic of Kosovo (Law No.05/L-053 On Specialist Chambers and Specialist Prosecutor's office 2015, Article 3). The Special Court will be composed of international judges and prosecutors appointed and financed by the EU, seated and operating in an EU member state (Law No.05/L-053 On Specialist Chambers and Specialist 
prosecutor's Office 2015, Article 27). After passing the constitutional amendment and the Law on Specialist Chambers, the EU is in the process of establishment and operationalisation of the Special court. The Netherlands has concluded with Kosovo an international agreement to host the seat of the Special Court, and the EU has already accorded financial support for it (an estimated $€ 300$ million) and has begun its staffing (Balkan Transitional Justice, 2016). The rules of procedure have been adopted however at the time of this writing no indictment is in place. Establishment of Special Court has caused controversy and hostility within the Kosovo society. The courts establishment is not supported by large part of the Albanian community because they consider it to be biased and unfair (Justice in Conflict 2017). Nevertheless, it is expected that establishment and the operationalization of the Special Court will have an imminent relevance for transitional justice processes and with it contribute to the Kosovo's EU integrative intentions.

\section{TRANSITIONAL JUSTICE IN KOSOVO AND THE EU ACCESSION}

In Copenhagen in 1993 the European Council established in its meeting the conditions for EU membership, which included "stability of institutions guaranteeing democracy, the rule of law, human rights and respect for and the protection of minorities" and provided financial assistance for countries in the region to strengthen democratic institutions and the rule of law as a way to "advance regional cooperation as well as reconciliation" (Council Regulation (EC) No 1085/2006 2006). Cooperation with the ICTY became a condition for membership candidacy, as spelled out in the Thessaloniki Agenda for the Western Balkans: "The EU urges all concerned countries and parties to co-operate fully with the International Criminal Tribunal for the former Yugoslavia. Recalling that respect for international law is an essential element of the SAP [Stabilisation and Association Process], the EU reiterates that full co-operation with ICTY, in particular with regard to the transfer to The $\mathrm{H}$ ague of all indictees and full access to documents and witnesses, is vital for further movement towards the EU" (General Affairs \& External Relations 
Council 2003). Concerning Kosovo since 2002 there has been an intensification of the EU-Kosovo cooperation, marked with a number of important developments leading to practical effect to Kosovo's 'EU perspective'. In October 2012 the European Commission initiated the feasibility study for a Stabilisation and Association Agreement (SAA) between the EU and Kosovo (European Commission (2012a). The contents of the Commission's report were broadly endorsed by the Council in December (Council of the European Union 2012). Kosovo was subsequently judged, in a joint report issued in April 2013 by the Commission and the High Representative of the Union for Foreign Affairs and Security Policy, to have met the benchmarks (European Commission and High Representative of the European Union for Foreign Affairs and Security Policy 2013a). On 19 April 2013, after months of very difficult and protracted EUmediated talks, including ten rounds at Heads of Government and EU High Representative level, a modality - based on an outline, fifteen points deal - was reached between the two sides (First Agreement of Principles Governing the Normalization of Relations 2013). On 22 April the Commission issued recommendations to the Council that negotiations should be opened on a SAA between the EU and Kosovo (European Commission 2013). The Council welcomed the recommendations but it left the final acceptance decisions to be taken by the European Council at its meeting in June 2013. The signing of Stabilization and Association Agreement (SAA) took place on 22 October 2015 establishing the contractual relationship between EU and Kosovo authorities which entails mutual rights and obligations and covers a wide variety of sectors. With the signing of the SAA the EU made transitional justice part of the Kosovo accession demands. In December 2015, the Government of Kosovo approved its National Action Plan for the Implementation of the Stabilization and Association Agreement (NAPISAA). The General Principles of the SAA, included within the NAPISAA oblige Kosovo Government to approve a National Transitional Justice Strategy which will define the modality for dealing with the past and reconciliation in Kosovo. Despite the fact that the Inter-ministerial Working Group for Dealing with the past and Reconciliation has been established back in 2012(Decision No.03/77, 04.06.2012. updated and amended with the Decisions No. 06/181, dated 02.04.2014 and No.04/200 dated 15.10.2014) still there is no 
document in a form of a national strategy in place. It has been stated that the work of the IMWG in the process of drafting the strategy "was hampered by deficiencies related to leadership and management, political ownership, representation and participation of Kosovo's minority communities, and engagement of the public, among others(A hmetaj and U nger 2017). The IM W G activities are not present in public, and it is hard to learn if IMWG is functional or not. Considering the mentioned shortcomings, there is a high risk that the IM W G will fail to develop a N ational Strategy that has the credibility and legitimacy to advance societal transformation" (Ahmetaj and Unger 2017).

On the other hand the EU facilitated dialogue for normalisation of relations between Prishtina and Belgrade has been initiated back on 8 March 2011. Since then, a considerable number of technical agreements regulating the cadastre, civil registry books, customs stamp, recognition of the university diplomas, freedom of movement, regional representation, integrated boundary management (IBM), official visits and liaison officers, collection of customs duties, development fund for the Northern Kosovo, vehicle insurance, free trade, the "Peace Park" in Mitrovica, civil protection and the dialogue of Chambers of Commerce have been reached between Kosovo and Serbian authorities including the latest agreement on judiciary on October 2017 (European Union External Action, Dialogue between Belgrade and Pristina 2017). However to date the issue of dealing with the past and the transitional justice process have not been discussed in the Prishtina -Belgrade dialogue despite the fact that CSOs and associations of the victims' families have requested the Kosovo authorities bring these issues in to the discussion table. The "political elites in Kosovo and Serbia still perceive the Transitional Justice process "as harmful to their respective national interest, humiliating for the ethno-nationalist factions, and consequently, Transitional Justice mechanisms were implemented through international, domestic and hybrid trials" (Morreale 2015). The lack of cooperation with Serbia in prosecuting war crimes remains the biggest challenge for bringing justice for war crimes (Kosovo 2.0 2017). All this elements are hampering the initiation of the overall and meaningful transitional justice processes that would lead to sustainable peace and reconciliation. 
While under UNMIK administration, $\mathrm{n}$ order to address the very painful part of the past that of missing persons from all parties affected by the conflict irrespective of their ethnic background, the Assembly of Kosovo has established the Commission on Human Rights, Gender Balance, Missing Persons and Petitions mandated to address the issue of missing persons. The Commission has been vocal in calling for responsibility from the Kosovo Government; they have not however developed any strategies or initiated any specific measures. The successful resolution regarding the fate of missing persons is conditioned by the success of prosecution and trials of war crimes, and Serbia's stance on the past which is evidenced in the Prishtina -Belgrade dialogue. Back in 2004, during the internationally mediated dialogue between Prishtina and Belgrade on technical issues, both governments agreed on the establishment of a Working Group on Missing Persons which held its first meeting in March 2005 (ICRC Press Release 2005). The government representatives of both parties were mediated by the International Committee of the Red Cross (ICRC) and the Kosovo delegation was accompanied by UNMIK. Although both governments verbally accepted the responsibility to keep the working group going, no real progress was made regarding sharing sensitive information doe to political reasons. The political changes after Kosovo's declaration of independence, have delayed the progress of the Working Group, and with it the disclosure of the fate of the missing persons. The slow progress and the agony related to the lack of resolution of the fate of the missing persons, abstention and not appropriately dealing with the war crimes cases affects also the process of returns which remains critical for the minority communities in Kosovo. After the adoption of the Constitution, a Consultative Council for Communities (CCC) has been established under the auspices of the President of Kosovo (Law No. 03/L-047). The CCC has the mandate to act as a liaison mechanism between the communities and the government. The CCC is now a constitutionally-mandated institution, comprising community representatives from both civil society and political parties, and key government officials. A similar mandate applies also to the Office for Communities established within the Office of the Prime Minister. The Office for Communities has been established to act as a promoter of communities' rights which will receive vast attention from the government. The 
other institutional framework of minority consultative bodies consists of the Committee on Rights and Interests of Communities, based in the Kosovo Assembly, and Commissioner for usage of languages within the Prime Minister Office. These minority consultative bodies have been initiated by the international community, and their establishment and functioning is seen as an appropriate for ensuring that constitutional commitments on minority rights are effectively implemented through direct engagement with minority representatives in consultative, decision-making and coordination processes (Visoka \& Beha 2011). Related to the status of civilian victim's while the Kosovo Assembly adopted the 'Law on Status and Rights of the families of Martyrs, KLA War Invalids and Veterans, and the Families of Civilian Victims of War' (Law No. 04/L-054 2011).The Law covers the following victim groups: Veterans of KLA and their families, Invalids of KLA, War hostages o Missing KLA soldiers, Civilian victims, Civilian hostages, Civilian missing persons (Law No. 04/L-054 2011, Article 2).The benefits comprise cash-based compensation and non-cash based compensation. In regard to the conflict related crimes of sexual violence the former President of Kosovo, Mrs. Atifete Jahjaga, has decreed the establishment of the National Council for the Survivors of Sexual Violence during the War on March 5, 2014. In accordance with the Constitution and laws of the Kosovo, the Council aims to coordinate the work and activities of institutions and the civil society, based on their scope, for the treatment of survivors of sexual violence during the war. Under her sponsorship the Regulations of procedure for the National Council for Survivors of Sexual Violence during the War has been drafted, the National Council for the Survivors of Sexual Violence has been established and the budget for the victims has been allocated. The Civil Society's activities on transitional justice are related to collection of data's and their documentation, few organizations working for interethnic dialogue, and some supporting truth -finding grassroots initiative to establish a regional truth commission in the former Yugoslavia known as RECOM. Despite all these initiatives the overall consultation processes involving all communities in Kosovo has not taken place du to the fact that there are different perceptions on the conflict and the narrative of the past by the 
communities on the conflict itself and the role of international community in Kosovo.

On February 2017 the President of Kosovo, Hashim Thaci, has announced plans to establish a truth and reconciliation commission to help reconcile Kosovo's ethnic-Albanian majority and Serb minority. According to President Thaci the truth commission will not replace the dialogue between Kosovo and Serbia, but it will be a facilitator in improving of relations between the two countries (Reuters 2017). Since February 2017, several consultative meetings under the leadership of the Office of the President have taken place where representatives of all communities, religious leaders and representatives of CSOs have taken part. During these consultative meetings it was expressed the will to undertake the overall and all-inclusive consultation process in order to best decide the way forward in bridging the existing gap between the communities. It is expected that the Truth Commission for Kosovo will be established by the end of 2017 . While president Thaci claims that "the aim of this commission will be the truth as the way to heal society from revenge and hatred," (Balkan Transitional Justice, Kosovo 'Trapped by the Past', Thaci 2017) analysts have questioned what the proposed Truth and Reconciliation Commission can achieve in practical terms in Kosovo's deeply divided society and also have questioned its timing. If the Truth and Reconciliation Commission is established "as part of some political bargaining between him (the President) and the international community under the pretext of stability and peace, then the Truth Commission is doomed to fail" (Ahmetaj 2017). However, at this stage it remains to be seen if this initiative is a genuine one or establishment of this commission is only for the political calculations and for satisfying the EU conditionality.

\section{CONCLUSIONS}

From the analyses of the constitutive documents establishing the international organizations, policies undertaken, development of tools and guidance for supporting transitional justice processes it is evident that the UN and EU have placed transitional justice processes as crucial element wards achieving peace 
and international justice. Though specifically not mentioned in their constitutive documents international organizations like the UN and EU have integrated the concept and initiatives in policy documents and strategies, and above all, in their peace building missions. The EU establishes the framework of Transitional Justice through a variety of sources and legal texts. However, the majority of references to Transitional Justice are found in declarations, reports and consensus documents. However, adopting transitional justice as an EU approach in all post conflict situations could help it achieve these commitments. Transitional justice is not a new policy area for the EU member states. The experience that some of them EU member states have could serve as a leading practice in establishing such an approach. In the case of Kosovo it seems unlikely that the EU support after its declaration of independence, will go beyond support for the work carried out by the International Tribunal for the former Yugoslavia, the work of EULEX judges in the mix tribunals in Kosovo and the activities of the Special court for Kosovo. Up to now EU through EULEX was partially involved in transitional justice processes through the retributive measures, placing intenrationla judges in hybrid courts, initiation and prosecution of war crime cases, and capcity building of teh local judges in handlin the war crime cases. The work of international judges, first of the UNMIK and latter of EULEX is to be respected despite the criticism. However, only instituting retributive measures are not enough in dealing with the past violations and bridging the existing interethnic divide in Kosovo. The above analysis moreover indicate that although the EU did acknowledge restorative justice as a legitimate part of transitional justice, in Kosovo it did not attest to true recognition of the urgent need for restorative transitional justice mechanisms. Considering that the current dialogue between Prishtina and Belgrade is concentrated only on solving the technical matters and the division that exist between the two communities formerly in conflict it is unlikely that the restorative mechanism will be initiated through the dialogue. Therefore, the international presence especially EU should adopt a strategy that would encompass a restorative approaches to transitional Justice - that will lead to reconciliation of communities. supporting the activities that will contribute to interethnic dialogue, developing activities with social, economic and educative 
characters that will bring together communities, working with different groups within the communities like women and youth are among the few modalities that could have laid the grounds for communication and with it support the cooliving. Above all a proactive involvement of local population and community representatives in the activities and decision making by the international presences could have provided international presences with insights on the needs of the communities. Only insisting on purely judicial measures in postconflict situations may have the opposite effect to what is desired and may prevent the realization of peace and stability. However, the EU in Kosovo will have an important part to play in the future supervision of the process of SAA, a situation which indeed will lead to the implementation of the Transitional Justice strategies to help lay the foundation for reconciliation between the Albanian majority and the Serb minority. Rather than remaining simply a supporter of transitional justice endeavours undertaken by others, the EU should also draw on its experience at home and abroad, and on lessons learnt from other actors such as the UN, to develop a strategic approach to transitional justice as a way of achieving its foreign policy objectives. This could help close the credibility gap between declared commitments to peace, human rights and international law and their realization.

\section{REFERENCES}

- $\quad$ Ahmetaj N., and Unger Th., Kosovo's Framework for Dealing With the Past at a Turning Point: Civil society review of progress towards a National Strategy on Transitional Justice accessed 3 November, 2017: file:/ / / C:/Users/IBCM-AC002/Downloads/civil-society-review-report-finaleng.pdf .

- $\quad$ Amnesty International, 2000. Federal Republic of Yugoslavia (Kosovo): setting the standard? UNMIK and KFOR's response to the violence in M itrovica. Accessed 23August 2017: https://www.amnesty.org/download/Documents/140000/eur700132000en.pd. - Amnesty International, 2004a. Kosovo and Bosnia-Herzegovina: the apparent lack of accountability of international peace-keeping forces in Kosovo 
and Bosnia-Herzegovin, 21 March 2004. • Accessed 25 June 2017: https://www.amnesty.org/en/documents/eur05/ 002/2004/en/.

- $\quad$ Amnesty International, 2004b. Serbia and M ontenegro (Kosovo/Kosova): The M arch violence: KFOR and UNMIK's failure to protect the right of the minority communities. Accessed 5 July 2017: https://www.amnesty.org/en/search/..Amnesty International. 2012 Kosovo: Time for EULEX to prioritize war crimes. Accessed 12 September 2017: http://www.amnesty.eu/content/assets/260412_EULEX_Report.pdf.

- Assemblée Parlementaire Du Conseil De l'Europe Resolution 1782 (2011)1 Final version Investigation of allegations of inhuman treatment of people and illicit trafficking in human organs in Kosovo. Accessed on 3 November 2017: http:/ / semanticpace.net/tools/pdf.aspx?doc=aHR0cDovL2Fzc2VtYmx5LmNvZS5pbnQvbncve G1sL1hSZWYvWDJILURXLWV4dHIuYXNwP2ZpbGVpZD0xNzk0MiZsYW5nP UVO\&xsl=aHR0cDovL3NlbWFudGljcGFjZS5uZXQvWHNsdC9QZGYvWFJlZi1 XRC1BVC1YTUwyUERGLnhzbA==\&xsltparams=ZmlsZWlkPTE3OTQy\#x0026;1 ang=en .

- $\quad$ Balkan Transitional Justice, 'Kosovo's New War Court: Major Challenges Ahead', Accessed on

November,2017:http:/ / www.balkaninsight.com/en/article/kosovo-s-new-warcourt-major-challenges-ahead-08-11-2015 .

- $\quad$ BC News, Kosovo parliament approves special war crimes court 4 August 2015. Accessed 3 noveber 2017: http://www.bbc.com/news/worldeurope-33770897 . Borchardt B., EULEX Head of Mission EULEX and War Crimes. Accessed 20 September, 2017: http://www.eulexosovo.eu/en/news/000427.php.

- Balkan Insight, Balkan Transitional Justice, Kosovo 'Trapped by the Past': Thaci, 01 2017. Accessed 3 November 2017: https:/ / www.balkaninsight.com/en/article/kosovo-trapped-by-the-past-thaci-03-012017.

- $\quad$ Bernhardt D. and Ferizi, A. 2011. The ICO and Dealing with the Past in Kosovo: Interview with Nora Raefeille," Made in Kosovo 6 (2011).

- $\quad$ Cerone, J. \& Baldwin, C. (2004). Explaining and Evaluating the UNMIK Court System. Internationalized Criminal Courts: Sierra Leone, East Timor, Kosovo, and Cambodia Eds by C.P.R. Romano: Oxford University Press.

Council of Europe, European Convention for the Protection of Human Rights and Fundamental Freedoms, as amended by Protocols N os. 11 and 14, 4 November 
1950, ETS

5.

Accessed 8

October

2017::

http://www.refworld.org/docid/3ae6b3b04.html ;

- $\quad$ Constitution of Republic of Kosovo, 2008. Accessed 12 September, 2017 : http://www.kryeministri-ks.net/repository/docs/Constitution1Kosovo.pdf

- Comprehensive Proposal for the Kosovo Status Settlement. 2007. Accessed 10

October,

2017:

https://www.kuvendikosoves.org/common/docs/Comprehensive\%20Proposal $\% 20$.pdf . 975/1999).

Council Regulation (EC) 975/1999 OJ L120/1, 1999, Art 2. (Regulation - $\quad$ Council Regulation (EC) No 1085/2006of 17 July 2006 establishing an Instrument for Pre-Accession Assistance (IPA)

- Council of the European Union (2012), Council Conclusions on Enlargement and Stabilisation and Association Process, General Affairs Council meeting, Brussels. Accessed 11 September, 2017: http://www.consilium.europa.eu/uedocs/cms_data/docs/pressdata/EN/gena ff/134235.pdf . Committee on Legal Affairs and Human Rights, Inhuman treatment of people and illicit trafficking in human organs in Kosovo*1 Report Rapporteur: Mr Dick Marty, Switzerland, Alliance of Liberals and Democrats for Europe. Accessed on 3 November, 2017: http://www.assembly.coe.int/CommitteeDocs/2010/ajdoc462010prov.pdf .

- $\quad$ Davlis L., The European Union and Transitional Justice. This paper was prepared in the framework of the Civil Society Dialogue Network (CSD N), 3 April 2014 in Brussels. Acessed on 3 November 2017: http://eplo.org/wpcontent/uploads/2017/02/EPLO_CSDN_Background-Paper_EU-and-

Transitional-Justice.pdf .

- $\quad$ Di Lellio A. and MeCum C. 2012. Engineering Grassroots Transitional Justice in the Balkans: The Case of Kosovo East European Politics and Societies. East European Politics and Societies. Accessed 10 September, 2017: http://www.annadilellio.com/wp-content/uploads/2013/08/TJKosovo.pdf .

- $\quad$ De Wet E. The Governance of Kosovo: Security Council Resolution 1244 and the Establishment and Functioning of EULEX. The American Journal of International Law, Vol. 103, No. 1 (Jan., 2009), pp. 83-96.Decision No.03/77, 04.06.2012. updated and amended with the Decisions No. 06/181, dated 02.04.2014 and No.04/200 dated 15.10.2014. Accessed on 3 November, 2017: http://www.kryeministri-

ks.net/repository/docs/RREGULLORE_QRK_Nr_18_2014_PER_PUNEN_E 
_GRUPIT_PUNUES_PER_BALLAFAQIM_ME_TE_KALUAREN_DHE_PAJTIM. pdf .

- $\quad$ European Union Rule of Law Mission (EULEX). Accessed 12 September, 2017: http:/ / www.eulex-kosovo.eu/en/info/whatisEulex.php .

- $\quad$ European Commission and High Representative of the European Union for Foreign Affairs and Security Policy (2013a) Joint Report to the European Parliament and the Council on Kosovo's Progress in Addressing Issues Set Out in the Council Conclusions of December 2012 in View of a Possible Decision on the Opening of Negotiations on the Stabilisation and Association Agreement, Brussels, 22 April, JOIN (2013). Accessed 10 October, 2017: http:/ / ec.europa.eu/enlargement/pdf/key_documents/2013/ks_spring_report _2013_en.pdf.

- European Union, Treaty on European Union (Consolidated Version), Treaty of Maastricht, 7 February 1992, Official Journal of the European Communities C 325/5; 24 December 2002. Accessed 11 September 2017: http:/ / www.refworld.org/docid/3ae6b39218.html .

- $\quad$ European Commission, “The Multiannual Financial Framework: The External Action Financing Instruments", MEMO/13/1134.

- $\quad$ European Security Strategy approved at the European Council meeting held in Brussels on the 12th of December 2003. Accessed 10 October 2017: https://www.consilium.europa.eu/uedocs/cmsUpload/78367.pdf .

- $\quad$ European Union: The EU's Policy Framework on support to transitional justice. $\quad$ Accessed $10 \quad$ October2017: http:/ / eeas.europa.eu/top_stories/pdf/the_eus_policy_framework_on_support _to_transitional_justice.pdf.

- $\quad$ European Union, Treaty Establishing the European Community (Consolidated Version), Rome Treaty, 25 March $1957 . \quad$ Accessed: http:/ / www.refworld.org/ docid/3ae6b39c0.html.

- $\quad$ EU Guidelines to EU Policy Towards Third Countries on Torture and Other Cruel, Inhuman or Degrading Treatment or Punishment. Accessed 10 October 2017: http:/ / www.consilium.europa.eu/uedocs/cmsUpload/TortureGuidelines.pdf . - $\quad$ European Commission (2012a) Communication From the Commission to the European Parliament and the Council on a Feasibility Study for a Stabilisation and Association Agreement Between the European Union and Kosovo, Brussels, 10 October, Com (2012) 602 final. Accessed on 18 September 2017: 
http:/ / ec.europa.eu/enlargement/pdf/key_documents/2012/package/ks_feasi bility_2012_en.pdf.

- $\quad$ European Commission (2013) Recommendation for a Council Decision Authorising the Opening of Negotiations on a Stabilisation and Association Agreement Between the European Union and Kosovo, Brussels, 22 April, COM (2013) $200 \quad$ final, $\quad$ Accessed 2 September 2017: http:/ / ec.europa.eu/enlargement/pdf/key_documents/2013/ks_recommendati on_2013_en.pdf .

- European Union External Action, EULEX and War Crimes. Bernd Borchardt, EULEX Head of Mission. Accessed 3 November 2017: http:/ / www.eulex-kosovo.eu/en/news/000427.php

- $\quad$ European Union External Action, Dialogue between Belgrade and Pristina, 2017. Accessed on 3 November 2017: https:/ / eeas.europa.eu/topics/eufacilitated-dialogue-belgrade-pristina-relations_en .

- $\quad$ EULEX report to the UN, 17 June 2009,.Acessed 3 November 2017: http://www.eulex-kosovo.eu/en/pressreleases/0049.php .

- $\quad$ First Agreement of Principles Governing the Normalisation of Relations. Accessed $12 \quad$ September 2017: http://www.kryeministriks.net/repository/docs/FIRST_AGREEMENT_OF_PRINCIPLES_GOVERNING _THE_NORMALIZATION_OF_RELATIONS,_APRIL_19,_2013_BRUSSELS_en.p df.

- file:///C:/Users/PC/Downloads/TJ_Guidance_Note_March_2010FIN AL\%20(1).pdf.

- Hayner Priscilla 1994 "Fifteen truth commissions, 1974 to 1994: a comparative study." Human Rights Quarterly 16: 597-655

- $\quad$ Hayner, Priscilla (2001) Unspeakable truths. New York: Routledge.

- Human Rights Watch, 2004. Failure to protect anti-minority violence in Kosovo, March 2004. Accessed 5 July 2017: https:/ / www.hrw.org/report/2004/07/25/failure-protect/anti-minorityviolence-kosovo-march-2004.General Affairs \& External Relations Council (GAERC). Extracts from successive General Affairs \& External Relations Councils 16 June 2003. Accessed 10 October 2017: http:/ / www.consilium.europa.eu/ueDocs/cms_Data/docs/pressdata/en/gena /76201.pdf .

- $\quad$ ICRC Press Release, Kosovo: First meeting of working group on missing persons 11-03-2004 News Release. Accessed 12 September 2017: 
https://reliefweb.int/report/serbia/kosovo-meeting-working-group-missingpersons.

- Institute for Democracy and Conflict Resolution: Briefing Paper Transitional Justice 2011.

- International Crisis Group, 2004. Collapse in Kosovo. Europe Report No. 155, 22 April, 2004. Accessed on 5 July 2017: https://www.files.ethz.ch/isn/28082/155_collapse_in_kosovo_revised.pdf.

- Jacque, J.P. (2015). Review of the EULEX Kosovo Mission's Implementation of the Mandate with a Particular Focus on the Handling of Recent Allegations. Accessed on 13 September 2017: eeas.europa.eu/statementseeas/docs/150331-jacque-report-en.pdf> .

- Justice in Conflict, "It is a good thing that we don't know." - An Interview with Bekim Blakaj on the Travails of Transitional Justice in Kosovo, 11 September 2017. Accessed on 3 November 2017: https://justiceinconflict.org/2017/09/11/it-is-a-good-thing-that-we-dont-knowan-interview-with-bekim-blakaj-on-the-travails-of-transitional-justice-inkosovo/.

- Kosovo 2.0 Nora Ahmetaj, Kosovo President must be Careful when establishing the Truth and Reconciliation Commission, 28, 02, 2017. Accessed on 3 November 2017: http://kosovotwopointzero.com/en/president-must-carefulestablishing-truth-reconciliation-commission/.

- Kosovo 2.0, Drita Hajdari. Without Cooperation with Serbia it is Impossible to Bring Justice for War Crimes, by Leonora Aliu, 13.04.2017. Accessed 3 November 2017: http://kosovotwopointzero.com/en/drita-hajdariwithout-cooperation-serbia-impossible-bring-justice-war-crimes/ .

- Law No. 04/L-054 On the Status and the Rights of the Martyrs, Invalids, Veterans, Members of Kosova Liberation Army, Civilian Victims of War and Their Families. Accessed on 3 November 2017: http://www.kuvendikosoves.org/common/docs/ligjet/Law\%20on\%20the\%20s tatus $\% 20$ of $\% 20$ the $\% 20$ martyrs\%20of\%20war.pdf.

- Law on the Protection and Promotion of the Rights of Communities and their Members in Kosovo Law no 03/1 -04712. Accessed 1 September 2017: http://www.gazetazyrtare.com/egov $/$ index.php?option=com_content\&task=view\&id=148\&Itemid=56\&lang=en.

- Law ON SPECIALIST CHAMBERS AND SPECIALIST PROSECUTOR'S OFFICE, Law No.05/L-053. Accessed on 3 November 2017: https://www.kuvendikosoves.org/common/docs/ligjet/05-L-053\%20a.pdf . 
- Military-Technical Agreement, signed between KFOR and Yugoslav Serbian Forces on June 9, 1999. Accessed on 13 September 2017: http://www.nato.int/kosovo/docu/a990609a.htm .

- Morreale V., Dealing with the past for a peace-built future Kosovo, 15 September 2016. Accessed on 3 November 2017: http://www.ks.undp.org/content/kosovo/en/home/presscenter/articl es/2016/09/15/dealing-with-the-past-for-a-peace-built-future-kosovo/ .

- Muižnieks N. 2012. Why does justice matter for reconciliation? Address on behalf of the Council of Europe Commissioner for Human Rights. Presentation in the conference Dealing with the Past and Reconciliation - What kind of truth seeking mechanism does Kosovo need?" International Civilian Office, Pristina, 22 May 2012. Accessed on 13 September 2017: https:// wcd.coe.int/com.instranet.InstraServlet?command=com.instranet.CmdB lobGet\&InstranetImage $=2109289 \&$ SecMode $=1 \&$ DocId $=1902992 \&$ Usage $=2$.

- $\quad$ Official Journal of the European Union, L115/50-56, 28 of April 2006. Accessed on 11 October 2017: http:// eur-lex.europa.eu/oj/direct-access.html - Official Journal of the European Union COUNCIL DECISION (CFSP) 2016/947 of 14 June 2016.Accessed on3 November 2017: http://www.eulexkosovo.eu/eul/repository/docs/COUNCIL\%20DECISION\%20CFSP\%202016947 .pdf .

- $\quad$ Philippe Kirshc Institute, Flexibility in Transitional Justice,31 July 2017. Accessed 3 November 2017: http://www.kirschinstitute.ca/flexibility-intransitional-justice/ .

- $\quad$ Rafaeli N. 2012.Challenges in Dealing with the Past in Kosovo: From Territorial Administration to Supervised Independence and Beyond, Politorbis Nr. $54-2 / 201 . \quad$ Accessed 10 October 207: http://www.pgaction.org/pdf/Politorbis_2_2012_No54_10th\%20anniversary\%2 0of $\% 20$ the $\% 20$ ICC.pdf .

- $\quad$ Regulation (EU) No 230/2014 of the European Parliament and of the Council of 11 March 2014 establishing an instrument contributing to stability and peace. Accessed 12 September 2017: http://ec.europa.eu/dgs/fpi/documents/140311_icsp_reg_230_2014_en.pdf .

- Report of the UN secretary General 2002. On the Rule of Law and Transitional Justice in Conflict and Post conflict Societies (S/2004/616).

- $\quad$ Reuters, Kosovo to form truth commission as wounds from 1998-99 war fester, World News, February 13, 2017. Accessed on 3 November 2017: 
http://www.reuters.com/article/uk-kosovo-president-commission/kosovo-toform-truth-commission-as-wounds-from-1998-99-war-fester-idUKKBN15S1U5 .

- $\quad$ Teitel G.R., Transitional Justice Genealogy, 16. Harvard Human Rights Journal Vo. 16 spring 2003, pp 69-94.

- United Nations Office of the United Nations High Commissioner for Human Right 2006. Rule-of law Tools for Post-conflict States Vetting: an operational framework. Accessed 10 September 2017: http://www.ohchr.org/Documents/Publications/RuleoflawVettingen.pdf .

- United Nations Secretary-General, The rule of law and transitional justice in conflict and post conflict societies (2004) UN Doc. S/2004/616.

- $\quad$ United Nations, Charter of the United Nations, 24 October 1945, 1 UNTS XVI. Accessed 8 October 2017: http://www.refworld.org/docid/3ae6b3930.html - UN General Assembly, International Covenant on Civil and Political Rights, 16 December 1966, United Nations, Treaty Series, vol. 999, accessed 8 October 2017:

- $\quad$ United Nations Guidance Note of the Secretary General United Nations Approach to Transitional Justice accessed 13 September 2017: http://www.refworld.org/docid/3ae6b3aa0.html .

- UN General Assembly, Convention Against Torture and Other Cruel, Inhuman or Degrading Treatment or Punishment, 10 December 1984, United Nations, Treaty Series, vol. 1465, p. 85.Accessed 8 October 2017: http://www.refworld.org/docid/3ae6b3a94.html.

- UN General Assembly, International Convention for the Protection of All Persons from Enforced Disappearance, 20 December 2006.Accessed 8 October 2017: http://www.refworld.org/docid/47fdfaeb0.html .

- UN General Assembly, Universal Declaration of Human Rights, 10 $\begin{array}{llllll}\text { December 1948, } 217 \quad \text { A } & \text { (III), accessed } 8 \text { October }\end{array}$ http://www.refworld.org/docid/3ae6b3712c.html .

- UN General Assembly, International Convention on the Elimination of All Forms of Racial Discrimination, 21 December 1965, United Nations, Treaty Series, vol. $\quad 660$. Accessed 8 October http://www.refworld.org/docid/3ae6b3940.html .

- UN General Assembly, Convention Against Torture and Other Cruel, Inhuman or Degrading Treatment or Punishment, 10 December 1984, United Nations, Treaty Series, vol. 1465. Accessed 8 October 2017: http://www.refworld.org/docid/3ae6b3a94.html. 
- UN General Assembly, International Convention for the Protection of All Persons from Enforced Disappearance, 20 December 2006. Accessed 8 October 2017: http://www.refworld.org/docid/47fdfaeb0.html.

- $\quad$ UN General Assembly, Convention on the Rights of the Child, 20 N ovember 1989, U nited Nations, Treaty Series, vol. 1577. Accessed 8 October 2017: http://www.refworld.org/docid/3ae6b38f0.html.

- UN General Assembly, Convention Against Torture and Other Cruel, Inhuman or Degrading Treatment or Punishment, 10 December 1984, United Nations, Treaty Series, vol. 1465, p. 85Accessed 8 October 2017: http://www.refworld.org/docid/3ae6b3a94.html .

- UN General Assembly, International Convention for the Protection of All Persons from Enforced Disappearance, 20 December 2006. Accessed 8 October 2017: http://www.refworld.org/docid/47fdfaeb0.html .

- United Nations Security Council Resolution 1244, 1999 U.N. Doc. S/RES/1244 (June 10, 1999).

- UNM IK (2008a) Report of the Secretary General on the United Nations Interim Administration Mission in Kosovo (UNMIK), 12 June, 2008. Accessed 2 September 2017:http://www.unmikonline.org/UNMIKONLINE 2009/misc/docs/sc-reports/S-2008-354.pdf .

- $\quad$ United Nations Security Council, The Rule of law and transitional justice in conflict and post-conflict societies, S/2004/616.

- UNMIK/REG/2000/66 21 December 2000 Regulation no. 2000/66 on benefits for war invalids of Kosovo and for the next of kin of those who died as a result of the armed conflict in Kosovo. Accessed 4 September 2017: http://www.unmikonline.org/regulations/2000/reg66-00.htm.

- Sission Jonathan: A Conceptual Framework for Dealing with the Past. 2010. Swisspeace. Accessed on 2 November 2017: http:// www.swisspeace.ch/fileadmin/user_upload/Media/Publications/DwP _Conceptual_Framework_October2012.pdf

- $\quad$ Statement by Samuel Žbogar, Head of the EU Office in Kosovo and EU Special Representative, 'The truth beyond any doubt (10/04/2014). 
- The Guardian, EU's biggest foreign mission in turmoil over corruption row. Accessed 12 September http://www.theguardian.com/world/2014/nov/05/eu-facing-questionsdismissal-prosecutor-alleged-corruption.

- $\quad$ Visoka G.and Beha A., Minority Consultative Bodies in Kosovo: A Quest for Effective Emancipation or Elusive Participation? Journal on Ethnopolitics and Minority Issues in Europe Vol. 10, No 1, 2011, pp.1-30.

- Ward, M., Gender, Citizenship and the Future of the Northern Ireland Peace Process, Eire-Ireland, 40: 3 \& 4, Fall/W in 2005. 


\title{
RUSSIAN - UKRAINIAN CONFLICT REVISITED: TOWARDS REGIME CHANGE IN RUSSIA?
}

\author{
Ryszard M. M achnikowski \\ Faculty of International and Political Studies, University of Lodz \\ Lodz, Poland \\ rmachnikowski@gmail.com
}

\begin{abstract}
A bstract
The "Ukraine crisis", as it is widely known, or more correctly, Ukraine - Russia war, started in 2013 - 2014, brought potentially devastating consequences for Central and Eastern Europe security and prospective functions of NATO military alliance. Previous Russian aggression, be it in Moldova or Georgia, went unpunished fact that created an impression that Russia had a "blank card" to do whatever it wanted within its "sphere of interests" (i.e. the territory of the former Soviet Union). Fortunately for the countries of NATO's "Eastern flank" and Scandinavian neighbours of Russia, the West ultimately responded to Moscow's military actions in the east of Ukraine. Economic and financial sanctions combined with the collapse of fossil fuels price have hit Russian economy and stopped Russia's involvement in this conflict. For the first time since the dissolution of the Soviet Union, Kremlin has been paying heavy price for its geopolitical manoeuvres. In this article I claim that as a result of Russian actions in Ukraine, this country is approaching "regime change", though the form of it remains unclear. The West should be prepared for the possible period of uncertainty in Russia, in order to minimize its possible negative consequences: period of social unrest and unknown profile and aims of future rulers of Russia.
\end{abstract}




\section{Keywords}

Conflict, crisis, regime change, Russia, sanctions, Ukraine, war

\section{RUSSIAN-KRAINIAN CONFLICT}

The history of Ukraine - Russia relations used to be complicated and consisted of ups and downs, but after Russia's military intervention in Ukraine in 2014 has reached previously unknown level of hostility. In this article I attempt to show that this "crisis" led to the unexpected, by the Kremlin's power elites, consequences. Despite territorial gains for Russia this country was met with far reaching reprisals from the West, resulting in rapid aggravation of the economic situation in Russia. This may influence the fate of power elite in this country as it reaches its climax.

The latest stage of the longstanding Ukraine - Russian "conflict" started in late autumn of 2013. Large part of the Ukrainian society was disappointed to see that their efforts to integrate with Western Europe were rejected by the government of Mr. Yanukovych, who succumbed to the enormous Russian pressure. In the summer of 2013 Russia undertook increasingly brutal economic and psychological actions aimed at changing Ukraine's pro-European political course. Much - awaited in Ukraine deal on co-operation with the EU had been long perceived by the Kremlin elite as a Western incursion into exclusive Russian "sphere of interest" and, consequently, as an existential threat for Russia. As a result, firstly Ukraine was threatened with the trade war - first shots of which were fired on 14 August, 2013 when Russian Custom Service stopped all imports coming from Ukraine. This increasing Russian economic pressure on the Ukrainian power elite should have come as no surprise - Russian officials used to issue warnings against "crossing the red lines" addressed to the West many times in the past (Kaczmarski 2009, Van Herpen 2015). In this way, Ukrainian oligarchical ruling class found themselves between the Scylla of the proEuropean expectations of a large part of their own population, located mostly in the Western part of this country (Chornohorska 2016) and Charybdis of the increasingly "assertive" Kremlin elites ready to defend ruthlessly their interests, 
with the use of force if necessary. On the one hand, quite a huge sector of Ukrainian society simply expected their country should enter the quick path towards integration with the EU, on the other, Moscow could have not accepted this move as leading to the prospective "loss" of Ukraine to Western institutions. In case of Ukraine, its rapprochement to the EU was perceived as at least equal danger as Georgian rapprochement to NATO - meaning loss of power and grip over these geopolitically important former Soviet republics.

President Yanukovych ultimately refused to sign an Association Agreement on co-operation with the EU, agreement that was planned to take form during the Summit of the European Union focused on Eastern Partnership on 28-29 November, 2013 in Vilnius. He was forced to follow his Kremlin patrons' orders (e. g. Pifer 2013) and by doing so he managed to disappoint strongly many Ukrainians, who also were determined to defend their dreams and aspirations. Ukrainian population has a long story of fights against their rulers, so it come as no surprise that on 21 November, 2013 Kiev's Maidan Nezalezhnosti (Independence Square) was flooded by masses of protesters, demanding first the cancellation of Yanukovych's decision and, finally, his resignation. On 30 November, 2013 events in Kiev entered their violent phase when the police forces started brutal crackdown on the demonstrators. Governmental violence was met with violence from the protesters, who attacked Berkut anti-riot police forces in reprisal (RT 2013). Since then protests spread out across Ukraine reaching the eastern parts of this country. They were countered with progovernment rallies and the establishment of the "Anti-maidan" movement, supported mainly in the East, inhabited by a huge Russian minority as well as the Russian-speaking Ukrainians, both holding pro-Russian attitudes (Interfax.ua 2013). By the mid - January 2014 Ukrainian government decided to introduce new legislation enabling it to dissolve demonstrations with the use of extensive force ad persecute the opposition (Al Jazeera 2014). This move was perceived as allowing "dictatorial powers" to the President and was considered to be a proof that Ukraine was sliding down into the Belarus-style dictatorship. On the Unity Day, 22 January, 2014 in Kiev two "Euromaidan" activists were shot dead by police (Union 2014) and a dead body of another Euromaidan activist shot by the "unknown perpetrators" was found on the outskirts of the city (Trach 2014). 
Despite this legal preparation for a massive crackdown on the Ukrainian opposition, when the tensions reached their highest point president Yanukovych decided to flee from Ukraine. He was soon followed by the Ukraine's Prime Minister Mykola Azarov and other government officials, who finally were found in Russia.

In this unexpected twist of fate, the power was literally lying in the streets of Kiev and pro-Russian forces in Ukraine abruptly lost their leaders. Kremlin must have perceived this situation as a severe threat for Russia's raison d'etat and decided to seek military solution to balance the rapidly growing "crisis" (Euronews 2014). The new government consisted of a staunch Ukrainian opposition, ready to put forward a pro-European policy that was much awaited by a large sector of Ukrainian society (BBC/2 2014). Russia's armed forces captured swiftly Crimea from within with the use of tactics which was a blatant violation of the international law of armed conflicts. So called "little green men" i.e. Russian soldiers without state distinctions appeared in the streets of Crimean towns and cities, quickly taking control of them. As we know today, quite a huge majority of senior officers in Ukraine's military willingly decided to join Russian side and were either disobeying resistance orders sent by their government or doing nothing to organize some armed defence against Russian soldiers (Polityuk, Zverev 2017). In any case, both the new government in Kiev and Western governments and public opinion seemed to be taken by a complete surprise with this show of Russian military might/power, and were unable to counter-react efficiently. In this way Russia managed to capture part of a land belonging to Ukraine, though perceived by some of Russians as their "native" zemlya (soil) (The Telegraph 2014). Russian forces promptly organized there a "referendum" on 16 March, 2014, the results of which were the basis for incorporating Crimea (RT 2014). On 18 March, 2014 the "Accession Treaty" between the "Republic of Crimea' and the Russian Federation was signed (Sputnik 2014) and on 21 March, 2014, it was finally approved by Russia's Federal Assembly. For Crimea the game was over - the speed and effectiveness of Russian actions, both military and "political" clearly shows that this kind of "scenario" has been prepared for Crimea for quite a long time. 
Hence, since the very beginning of the so called "Ukrainian crisis", Russian involvement was obvious and absolutely essential for understanding these events. As history shows, Kremlin elites had never respected the sovereign will of other nations if only it stood in opposition to their interests or plans. Russian annexation of the Crimean Peninsula was achieved almost without a single shot - there was hardly any resistance from the Ukrainian armed forces and "the World" had been left with no time to protest. What is noteworthy, the reaction of the "international community", including NATO and EU leaders, to this blatant violation of the international law was initially limited to the diplomatic condemnation and words of solidarity with the new Ukrainian government. It is worth reminding that the annexation of Crimea violated not only the so called Budapest Memorandum (signed by Ukraine, Russia and by two major NATOmembers: the U.S. and U.K.)1 but also the Partition Treaty on the Status and Conditions of the Black Sea Fleet, signed by Ukraine and Russia in May, 1997 and the 1991 Agreement Establishing the Commonwealth of Independent State. Russia not only did not cease its military action in Ukraine but was ready to extend it on the Eastern part of this country. The "destabilization" of Donbass and Luhansk regions happened very soon - "popular resistance" movement, organized by Russia, managed to capture large parts of the east of Ukraine (Rand 2017, Sutyagin 2015). Armed "militants", or "terrorists", as the new government in Kiev preferred to call them, were the local "militiamen" drafted for this occasion, including criminals - but guided, and controlled by Russian special services and special forces which supported this alleged "popular insurgency". The lands conquered by this "rebellion" were soon declared "independent" as Donetsk and Luhansk People's Republics (Wiener-Bronner 2014). But here Kremlin has not decided to copy the Crimea's "scenario" and, so far, has not incorporated these lands directly into Russian Federation. Annexation of these lands and establishment of the so called "Newrussia" could be perceived as an open grab of a large part of Ukrainian soil and would probably lead to the release of even more serious international outcry followed by another round of sanctions.

After initial absence of any Ukrainian counter-action, in April, 2014 the new government announced starting of the "antiterrorist" operation in the eastern 
part of the country. It was led by the newly created N ational Guard troops, backed by regular Army units, including artillery and airpower, and followed by western Ukraine "volunteers" drafted mostly from the Ukraine's nationalist movement. Ukrainian military forces quickly showed their upper hand over "popular militia" and started to regain pretty quickly the lost ground fact that led to a significant retreat of the "Novorossiya" forces, pushing "separatists" towards the border zone by the end of July 2014. This retreat provoked the intervention of the regular Russian military units, including armoured battalions, parachutists and heavy artillery, flooding Eastern Ukraine in August 2014 (Bidder et al. 2014). As the result, Russian troops not only regained all the land formerly seized by the "insurgents" but threatened to go further towards southern coastal city of Mariupol (Kramer and Gordon 2014). This Russian military advancement led newly elected Ukrainian president, Petro Poroshenko, to propose a permanent ceasefire agreement, which included the withdrawal of all heavy weapons on both sides and establishment of the "buffer zone" between Ukrainian military forces and pro-Russian "separatists". The Agreement called M insk protocol was signed on 5 September 2014 (OSCE 2014). The ceasefire lasted till January 2015 when heavy clashes between Ukrainian and "separatists" forces broke out around Donetsk International Airport and the city of Debaltsevo. Second ceasefire agreement called M insk II was signed in February 2015 (OSCE 2015) and since then the conflict has been "frozen", though minor clashes between opposing parties still happen and people, both soldiers, paramilitaries and civilians are still being killed there.

Russia is also accused of other forms of "destabilization" of Ukraine, namely supporting and organizing acts of terrorism, incursions of its military personnel and numerous assassinations in the Central and Western part of Ukraine which is under Kiev's governmental control (Oliphant 2017). Russian-built antiaircraft BUK missile operated by the "pro-Russian" forces (BUK - TELAR rocketlauncher was a belonging of the Russian 53 A nti-aircraft Rocket Brigade stationed in the city of Kursk) on 17 July, 2014, shot down Malaysian Boeing 777, flight MH17 what was a cause of an international outrage and confronted Western public with the real nature of the conflict in the east of Ukraine (JIT Info 2016). 
By its military involvement since the very beginning of this conflict Russia has managed to carry out the de facto partition of its neighbour. With the annexation of the Crimea and detachment of the eastern regions of Ukraine, Russia has deprived Kiev of control over a large part of its country and population. Exactly the same happened earlier to other neighbours of Russia - Georgia (so called " 5 days war" in August 2008) and the Republic of Moldova (the case of the so called "Transnistria" war 1990 - 92). This time, however, Moscow achieved results standing in huge contradiction to its expectations. Though initial diplomatic reactions from the EU, UN, USA and NATO to the ongoing "crisis" in Ukraine were rather anemic, and president Obama's administration finally took a notice that there was a growing "problem" with Russia only after the annexation of Crimea, Russia's actions in Ukraine ultimately led to imposing slow but persistent anti - Russian sanctions. The initial choir of Western academics, politicians and industrialists who were ready to talk about "caution" in assessment of the Russian involvement into ongoing military conflict and wowing for "understanding" of Kremlin motives and moves did not halt legal reaction to the Russian actions in Eastern Ukraine. Since spring 2014 Western countries and organizations gradually imposed increasingly severe economic sanctions on Russian companies, officials and individuals. They detached Russia banks from Western credit lines that apparently led to the collapse of Russian currency - ruble - and resulted in a financial crisis in Russia (Reuters 2014). Some countries, including Norway, Canada, Australia and Japan followed American and European decisions. Some sanctions were specifically targeting Crimea and complicated economic situation of this annexed region (RT/2 2014). First round of sanctions was associated with an illegal "referendum" which took place in Crimea and President Putin's recognition of this part of Ukraine as an "independent state" element which enabled its prompt annexation by Russia (White House 2014). Further sanctions followed Russia's aggressive military actions in Ukraine (International Trade Compliance Update 2014). Sanctions affected major Russian companies from the financial, energy and defence sectors as well as government officials and individuals considered to be personally involved in supporting and financing "terrorism" in Ukraine, and was met with outrage in Moscow. As a result, Russian economy gradually slowed down and 
some budgetary spending, including ambitious military programs, had to be limited (Reuters 2015, Fleischer 2015). What is more important, the developing Russia - Germany economic and political co-operation had to be halted German companies had no other choice but to limit significantly their involvement in Russia, as major contracts had been frozen (Meister 2015). Moreover, the price of fossil fuels on world's markets significantly decreased since the beginning of the "crisis" in Ukraine, fact that has severely affected Russia's budget, heavily dependent of the sale of Russian gas and oil.

Moreover, Russia's action in Ukraine effectively diverted Western policies towards this country based on the presumption that Russia had been a cooperative state and would have not threaten the post-Cold War political order in Europe and beyond. Subsequent Russian military actions in Syria proved that it should be contained through the show of military force, otherwise it could become a threat to the stability of Europe itself. As a result, many countries, particularly Russia's neighbours, including the Baltic States, Scandinavians and Romania, have initiated even closer co-operation with and within NATO to prepare for a possible Russian invasion (Witte 2014). The Baltic States felt particularly threatened as a possible military scenario repeating Ukrainian case could have been executed with ease on their territory (Borger and Harding 2014, Machnikowski 2015). Through its policy, Russia managed to reverse post - Cold War American policy based on the withdrawal of major USA troops from Europe - some military units, including armoured battalions came back to Europe and were located in NATO's "Eastern flank", including Baltic states, Poland and Romania (Batchelor 2017). USA air forces were also located closer to Russia and, together with other armed forces, were involved in military exercises to show the ability and commitment of America to defend its European allies (e. g. Cohen 2017). In June 2014, during his state visit to Poland, President Barack Obama declared the introduction of the European Reassurance Initiative (ERI) which covered the increase of the USA military presence in Europe in order to ensure the security of the European states against possible Russian aggression (BBC 2014). The direct result of ERI is the military O peration Atlantic Resolve and it includes rotational presence of an American heavy brigade and other military forces in Poland, Romania and the Baltic States. Most recently, under the aegis of 
the Operation Atlantic Resolve (US Army Europe 2017) more than 1,100 troops including 900 USA soldiers as well as 150 British and 120 Romanians were deployed in Orzysz in Northern Poland, which is close to Russia's Baltic Sea enclave of Kaliningrad. Through pretty modest military means (in comparison to the Cold War period levels) NATO attempts to contain further Russian aggressive moves and actions in its neighbourhood. Under Trump administration USA is even considering selling offensive lethal military equipment to Ukraine what might sharply increase Ukrainian military potential and boost Ukrainian's troops morale (Peterson 2017).

Through the annexation of Crimea and both direct and indirect military involvement into Ukrainian "crisis" Russia evoked Western reaction standing in deep contradiction to the previous experience, when USA and European powers decided to turn a blind eye to Russian military actions in the region of Russia's "close abroad". Previous "destabilization" of Moldova, resulted in a detachment of "Transnistria" from this country, and the open Russia's war with Georgia had not caused the West to change its attitude towards Putin's Russia (Asmus 2010). This "appeasement" type of approach might have persuaded his inner circle that the West was unable to respond boldly on Russian aggressive actions and hence they had a blank card to do whatever they find plausible - including aggression against neighbouring countries. Russian authorities probably had been pretty sure that another act of open interference in the internal affairs of its neighbour would have gone unpunished in any way. But to their surprise, this time both the USA and the EU decided to react firmly, though not promptly, to deter Russia at the borders of NATO. Despite Moscow's efforts to present itself as a military giant, Russian armed forces are still not a match to American and joint NATO forces. Hence, Russia cannot exceed the certain level of aggression in its actions. Politics by coercion has its limits but still Russia is prone to use available resources, other than military, to affect the situation in Europe. But instead of brute force, Russia prefers to use the so called "active measures" to influence foreign societies and governments (Snegovaya 2015, Kragh and Åsberg 2017). "Psychological information operations" seems to be the preferred weapon of choice used by Kremlin today as they give the Russians an option of "plausible denial" and usual 
bullying seems not to be as effective as it previously has been (Darczewska 2014, Darczewska 2016, Darczewska and Żochowski 2017).

Though it is hard to assess the effectiveness of Russian meddling with the use of "info-wars", it still tries to affect the political preferences of the Western public. This includes attempts to influence the results of elections (Sputnik 2017, Lipton, Sanger and Shane 2016) as well as creating an environment which is favourable to the development of the extreme political parties in the West. These parties may contribute to some form of "destabilization" of the political situation there and, by strange coincidence, they usually are much more pro-Russian than the political "mainstream" there (though obviously there are exemptions from this rule). Though Russia can contribute to the worsening of the situation in the West and spread unrest there due to its "hybrid" resources, it is paying a huge price for these

activities. Russian actions in Ukraine, Syria and against the Western public are major reasons for serious and longstanding deterioration of the Western - Russian relations. Despite the fact that it is much harder to prove Russia's power in cyberspace than in the real world, the U.S. has recently decided to impose new sanctions as a punishment for Russia's attempts to influence democratic procedures (Crawley 2017).

\section{CONCLUSIONS}

Through its overt and covert actions against Ukraine, Russia provoked initially slow but persistent collapse of relations both with Western Europe and the U.S. Financial sanctions which were primary reprisal tool in Western arsenal, combined with the low price of fossil fuels has caused economic crisis in this country. As ambitious military projects still consume vast part of the Russian budget, these military spending result in a decline of the living standard of ordinary Russians (Movchan 2017). Thirty years ago the predecessor of the Russian Federation, the Soviet Union, entered a very similar path - Soviet invasion of Afghanistan led also to Western economic sanctions and combined with the arms race resulted in the rapid decline of the Soviet economy. The rest of this story is already known to us. It is not a heresy to expect that the further deterioration of Russian economy may 
ultimately lead to the delegitimization of the current Russian power elites. The question remaining concerns the way the "regime change" would ultimately be realized in this country. Russia seems to approach a point the Soviet Union had reached shortly before its dissolution - the economy crumbles, living standard of ordinary people deteriorates, military spending is a growing burden for the financial situation, though still the authorities are willing to intervene abroad (Trenin 2017). Russia's intervention in Ukraine might be an equivalent of the Afghanistan disaster to the Soviets, though obviously with much lower level of fatalities among Russian soldiers there, but still harming the delicate fabric of its society. It is difficult to predict the way the transition of power can ultimately happen in this country - so let us hope when it happens it is going to be a relatively peaceful process rather than a violent one.

\section{AN NEX}

${ }^{1}$ They all signed six agreements for Ukraine, these agreements are:

1. The Russian Federation, the United Kingdom of Great Britain and Northern Ireland and the United States of America reaffirm their commitment to Ukraine, in accordance with the principles of the Final Act of the Conference on Security and Cooperation in Europe, to respect the independence and sovereignty and the existing borders of Ukraine;

2. The Russian Federation, the United Kingdom of Great Britain and Northern Ireland and the United States of America reaffirm their obligation to refrain from the threat or use of force against the territorial integrity or political independence of Ukraine, and that none of their weapons will ever be used against Ukraine except in self-defence or otherwise in accordance with the Charter of the United Nations;

3. The Russian Federation, the United Kingdom of Great Britain and Northern Ireland and the United States of America reaffirm their commitment to Ukraine, in accordance with the principles of the Final Act of the Conference on Security and Cooperation in Europe, to refrain from economic coercion designed to subordinate to their own interest the exercise by Ukraine of the rights inherent in its sovereignty and thus to secure advantages of any kind; 
4. The Russian Federation, the United Kingdom of Great Britain and Northern Ireland and the United States of America reaffirm their commitment to seek immediate United Nations Security Council action to provide assistance to Ukraine, as a non-nuclear-weapon State party to the Treaty on the Non-Proliferation of Nuclear Weapons, if Ukraine should become a victim of an act of aggression or an object of a threat of aggression in which nuclear weapons are used;

5. The Russian Federation, the United Kingdom of Great Britain and Northern Ireland and the United States of America reaffirm, in the case of Ukraine, their commitment not to use nuclear weapons against any nonnuclearweapon State party to the Treaty on the Non-Proliferation of Nuclear Weapons, except in the case of an attack on themselves, their territories or dependent territories, their armed forces, or their allies, by such a State in association or alliance with a nuclear-weapon State;

6. Ukraine, the Russian Federation, the United Kingdom of G reat Britain and $\mathbf{N}$ orthern Ireland and the United States of America will consult in the event a situation arises that raises a question concerning these commitments.

Source:https://treaties.un.org/doc/Publication/UNTS/No\%20Volume/50 069/Part/I-50069-0800000280338ba9.pdf

2 See e.g.: John Mearsheimer Why the Ukraine Crisis Is the West's Fault. The Liberal Delusions That Provoked Putin, "Foreign Affairs" September/October 2014; Niemcy: Były kanclerz Helmut Schmidt broni polityki Putina wobec Krymu, "Interia", 26 March 2014; "Die Zeit" ostrzega przed kandydatem na szefa dyplomacji.“Niech trzyma się z dala od MSZ”, "TVN24”, 2 October 2013; Niemiecki polityk: Działania Rosji skutkiem przyjęcia Polski do NATO, “Gazeta.pl”, 11 March2014; "Handelsblatt”: Krym należy do Rosji tak jak Vermont do USA, "Onet.pl", 13 March 2014; D. Heinrich, A. Wojnarowska, Niemieccy eksperci: „Demonizowanie Putina nie jest polityką, tylko alibi wobec jej braku", "Deutsche Welle", 20 March 2014; Niemcy: Eurosceptycy z AfD przeciw sankcjom wobec Rosji, "Interia”, 23 March 2014; Berlusconi broni Putina. "Niweczy się zbliżenie z Rosją", “Dziennik.pl”, 26 March 2014; Polityk Zielonych przeciwko rozlokowaniu oddziałów w Polsce. "Pobrzękiwanie szabelką", "TVN24", 3 April 2014; Impreza Schroedera z Putinem oburza prasę, ale nie Niemców. "To najbardziej przerażające", "TVN24", 30 April 2014; Schroeder dla "Die Welt": Nie izolować Putina, "Interia", 11 May 2014; Wpływowy niemiecki dziennik o natowskich , jastrzębiach" i "dolewaniu oliwy do ognia”, “TVN24", 8 
May 2014; M. Pawlak, „Tylko żadnych gestów militarnych”. Niemiecki ekspert o polityce NATO wobec Rosji, "Deutsche Welle", 23 May 2014; Francuska ultraprawica mówi głosem Rosji. Marine Le Pen popiera federalizację Ukrainy, “TVN24”, 12 April 2014; Niemiecka Lewica broni Rosji, "TVN24", 11 May 2014;

\section{REFERENCES}

- $\quad$ Al Jazeera. 2014. "Ukraine adopts tough anti-protest laws." Al Jazeera, January 17, 2014. http://www.aljazeera.com/news/europe/2014/01/ukraineadopts-tough-anti-protest-laws-2014116171328466370.html

- Asmus, Ronald. 2010. A Little War that Shook the World, Palgrave Macmillan, New York

- $\quad$ Batchelor, Tom. 2017. "The map that shows how many Nato troops are deployed along Russia's border." The Independent, February 5, 2017. http://www.independent.co.uk/news/world/europe/russia-nato-borderforces-map-where-are-they-positioned-a7562391.html

- $\quad$ BBC. 2014. "European Reassurance Initiative: Obama announces $\$ 1 \mathrm{bn}$ fund." BBC, June 3, 2014. http:/ / www.bbc.com/news/world-europe-27671691

- $\quad$ BBC/2. 2014. "EU signs pacts with Ukraine, Georgia and Moldova." BBC, June 27, 2014. http:/ / www.bbc.com/news/ world-europe-28052645

- $\quad$ Bidder, Benjamin, Gathmann, Moritz, Neef, Christian, Schepp, Matthias. 2014. “Undeclared War. Putin's Covert Invasion of Eastern Ukraine." D er Spiegel, September 2, 2014. http://www.spiegel.de/international/world/russiaexpands-war-in-eastern-ukraine-amid-web-of-lies-a-989290.html

- $\quad$ Borger, Julian, Harding Luke. 2014. "Baltic states wary as Russia takes more strident tone with neighbours." The Guardian, September 18, 2014. https://www.theguardian.com/world/2014/sep/18/baltic-states-wary-russiastrident-estonia-latvia-lithuania-nato

- Chornohorska, Anastasia. 2016. “Ukrainians overwhelmingly support European Integration." Euromaidan Press, April 1, 2016 http://euromaidanpress.com/2016/04/01/ukrainians-overwhelminglysupport-european-integration-infographics/\#arvlbdata

- $\quad$ Cohen, Zachary. 2017. "US bombers arrive in Europe as Russia preps for war games." CN N, August 24, 2017.http://edition.cnn.com/2017/08/23/politics/us-b-1-bombers-arrive-ineurope/index.html 
- Crawley, Michael. 2017. "Trump signs Russia sanctions bill he opposed." Politico, July 29, 2017.https://www.politico.eu/article/trump-signs-russiasanctions-bill-he-opposed/

Darczewska, Jolanta. 2014. "The anatomy of Russian information warfare. The Crimean operation, a case study". OSW Studies, vol. 42, OSW Warsaw.

- Darczewska, Jolanta. 2016. "Russia's armed forces on the information war front. Strategic documents", OSW Studies, vol. 57, OSW Warsaw.

- $\quad$ Darczewska, Jolanta, Żochowski, Piotr. 2017. “Active measures. Russia's key export", OSW Studies, vol. 64, OSW Warsaw.

- $\quad$ Euronews. 2014. "Full video: Putin's address on Crimea joining Russia, signing ceremony."

- Euronews,

March

14,

2014.https:/ / www.youtube.com/watch?v=Ayu3Ecdbl0Q

- Fleischer, Paweł. 2015. "Rosja tnie wydatki obronne. Program modernizacji kontynuowany."[Russia cuts the defence spending. The modernization program continues] Defence 24.pl, February 2, 2015.http:/ / www.defence24.pl/186770,rosja-tnie-wydatki-obronne-programmodernizacji-kontynuowany

- $\quad$ JIT info. 2016. "JIT: Flight MH17 was shot down by a BUK missile from a farmland near Pervomaiskyi." Openbaar Ministerie, Setember 26, 2016. https://www.om.nl/onderwerpen/mh17-crash/@96068/jit-flight-mh17shot/

- Interfax.ua. 2013. "Several thousand Regions Party activists continue rally in support of Yanukovych." Interfax, December 8, 2013.http:/ / en.interfax.com.ua/news/general/179986.html

- International Trade Compliance Update. 2014. "EU strengthens sanctions against actions undermining Ukraine's territorial integrity." ITCU, April 24, 2014.http:/ / www.internationaltradecomplianceupdate.com/2014/04/28/eustrengthens-sanctions-against-actions-undermining-ukraines-territorialintegrity /

- Kaczmarski, Marcin. 2009. „Russia's Revisionist Policy Towards the West", OSW Studies, Warsaw.http://www.osw.waw.pl/sites/default/files/prace_33.pdf

- $\quad$ Kragh, Martin, Åsberg, Sebastian. 2017. "Russia's strategy for influence through public diplomacy and active measures: the Swedish case", Journal of 
Strategic

Studies,

January

5 , 2017.http://dx.doi.org/10.1080/01402390.2016.1273830

- Kramer, Andrew Gordon, Michael. 2014 "Ukraine Reports Russian Invasion on a New Front." N ew Y ork Times, August 27, 2014.

- $\quad$ E. Lipton, D. E. Sanger and S. Shane. 2016. "The Perfect Weapon: How Russian Cyberpower Invaded the U.S." The New York Times, December 13, 2016.http://www.nytimes.com/2016/12/13/us/politics/russia-hack-electiondnc.html?hp\&action=click\&pgtype $=$ Homepage\&clickSource $=$ storyheading\&module=a-lede-package-region\&region=top-news\&WT.nav=topnews\&_r $=0$

- Machnikowski, Ryszard. 2015. „NATO and Ukraine crisis”, in: Czulda, Robert., Madej, Marek. Eds. Newcomers no more? Contemporary NATO and the Future of the Enlargment from the Perspective of the "Post-Cold War" Members, Warsaw - Prague - Brussels

- $\quad$ Meister, Stefan. 2015. "How Russia Lost Germany (and How it Can Win It Back)." Russia and Global Affairs, January/ March 2015.https://dgap.org/en/think-tank/research-programs/robert-bosch-centerfor-central-and-eastern-europe-russia-and-central

- Movchan, Andrey. 2017. “Decline, Not Collapse: The Bleak Prospects for Russia's Economy." Carnegie, February 2, 2017.http:/ / carnegie.ru/2017/02/02/ decline-not-collapse-bleak-prospects-forrussia-s-economy-pub-67865

- $\quad$ Oliphant, Roland. 2017. “Ukraine sues Russia in International Court of Justice for 'financing terrorism'." The Telegraph, March 6, 2017.http://www.telegraph.co.uk/news/2017/03/06/ukraine-suesrussia-international-court-justiceforfinancing/

- $\quad$ OSCE. 2014. “Minsk Protocol (in Russian)." OSCE Sepember 5, 2014. http:/ / www.osce.org/ru/home/123258?download=true

- $\quad$ OSCE. 2015. "Package of Measures for the Implementation of the Minsk Agreements (in Russian)." OSCE February 12, 2015.http:// www.osce.org/ru/cio/140221?download=true

- Peterson, Nolan. 2017. "Value of US Weapons Goes Far Beyond Battlefield, Ukrainian Troops Say." The Daily Signal, August 4, 2017.http:// dailysignal.com/2017/08/04/value-us-weapons-goes-far-beyondbattlefield-ukrainian-troops-say/ 
- $\quad$ Pifer, Steven. 2013. "Why Did Ukraine's Yanukovych Give in to Russian Pressure on EU Deal?" Brookings, December 2, 2013.https:/ / www.brookings.edu/onthe-record/why-did-ukraines-yanukovych-give-in-to-russian-pressure-on-eu-deal/

- $\quad$ Polityuk, Pavel, Zverev, Anton. 2017. "Why Ukrainian forces gave up Crimea without a fight - and NATO is alert." Reuters, July 24, 2017.http:/ / www.reuters.com/article/us-ukraine-crisis-crimea-

annexation/why-ukrainian-forces-gave-up-crimea-without-a-fight-and-nato-isalert-idUSKBN1A90G0

- Rand. 2017. Michael Kofman, Katya Migacheva, Brian Nichiporuk, Andrew Radin, Olesya Tkacheva, Jenny Oberholtzer "Lessons from Russia's Operations in Crimea and Eastern Ukraine." RAND Research Report, March 2017.https:/ / www.rand.org/pubs/research_reports/RR1498.html

- $\quad$ Reuters. 2014. "Russia entering "full-fledged economic crisis", says exminister Kudrin." Reuters, December 22, 2014.http:/ / www.reuters.com/article/russia-crisis/russia-entering-full-fledgedeconomic-crisis-says-ex-minister-kudrin-idUSL6N0U61L320141222

- Reuters. 2015. "Putin's defence fixation deepens Russian budget problems." Reuters, January 15, 2015.http://www.reuters.com/article/russiacrisis-budget/putins-defence-fixation-deepens-russian-budget-problemsidUSL6N0US25520150115

- $\quad$ RT. 2013. “Ukrainian police violently eject pro-EU protesters from Kiev square." RT, November 30, 2013.https://www.rt.com/news/ukraine-policedisperse-protest-509/

- $\quad$ RT. 2014. "Crimea declares independence, seeks UN recognition." RT, March 17, 2014.https://www.rt.com/news/crimea-referendum-results-official$250 /$

- RT. 2014 (2). “Obama authorizes 'economic embargo' on Russia's Crimea." RT, December 19, 2014.https://www.rt.com/usa/216143-obamasanctions-russia-crimea/

- Shevchenko, Vitaly. 2014. "Little green men" or "Russian invaders"?" BBC, March 11, 2014.

- $\quad$ Trach, Natalia. 2014. "Two EuroMaidan activists missing; foul play suspected." Kyiv Post, January 21, 2014.https://www.kyivpost.com/article/content/euromaidan/twoeuromaidan-activists-missing-foul-play-suspected-335343.html 
- $\quad$ Snegovaya, Maria. 2015. "Putin's information warfare in Ukraine. Soviet origins of Russia's hybrid warfare." Institute for the Study of War, September 2015.

- "Sputnik and Russia's New Theory of War." New York Times https:/ / www.nytimes.com/2017/09/12/us/politics/russia-facebookelection.html?hp\&action $=$ click\&pgtype $=$ Homepage\&clickSource $=$ storyheading\&module=second-column-region\&region=top-news\&WT.nav=top-news - $\quad$ Sputnik. 2014. "President Putin signs treaty to bring Crimea into Russia." Sputnik, March 18, 2014.https://sputniknews.com/voiceofrussia/news/2014_03_18/PresidentPutin-signs-treaty-of-joining-Crimea-Sevastopol-to-Russia-9079/

- $\quad$ Sutyagin, Igor. 2015. "Russian Forces in Ukraine”, RUSI papers, March 2015.https://www.rusi.org/downloads/assets/201503_BP_Russian_Forces_in_ Ukraine_FINAL.pdf

- The Telegraph. 2014. "Putin: 'Crimea has always been an integral part of Russia.'” The Telegraph, March 18, 2014.http:/ / www.telegraph.co.uk/news/worldnews/europe/ukraine/1070618 2/Putin-Crimea-has-always-been-an-integral-part-of-Russia.html

- Trenin, Dmitri. 2017. “Demands on Russian Foreign Policy And Its Drivers: Looking Out Five Years", Carnegie. http:/ / carnegie.ru/commentary/72799

- Union. 2014. “Одного из погибших сегодня застрелил снайпер, второго убили из пистолета Union”, January 22, 2014.

https:/ / www.unian.net/politics/875272-odnogo-iz-pogibshih-segodnyazastrelil-snayper-vtorogo-ubili-iz-pistoleta-vrachi.html

- $\quad$ US Army Europe. 2017. "Atlantic Resolve."

http:/ / www.eur.army.mil/ AtlanticResolve/

- Van Herpen, Marcel H. 2015. Putin's Wars. The Rise of Russia's New Imperialism, Rowman \& Littlefield Publishers: Lanham.

- White House. 2014. Executive Order -- Blocking Property of Certain

Persons Contributing to the Situation in Ukraine." White House, March 6, 2014. https://obamawhitehouse.archives.gov/the-pressoffice/2014/03/06/executive-order-blocking-property-certain-personscontributing-situation

- Wiener-Bronner, Danielle. 2014. "Referendum on Self-Rule in Ukraine 'Passes' with Over 90\% of the Vote." The Atlantic, May 12, 2014. 
https://www.theatlantic.com/international/archive/2014/05/referendum-onself-rule-in-ukraine-passes-with-over-90-of-the-vote/362062/

- Witte, Griff. 2014. "Finland feeling vulnerable amid Russian provocations." The Washington Post, November 23, 2014. https://www.washingtonpost.com/world/europe/finland-feeling-vulnerableamid-russian-provocations/2014/11/23/defc5a90-69b2-11e4-bafd6598192a448d_story.html?utm_term=.d0e5dfed03b6

\section{Bio}

Ryszard Machnikowski is the vice-dean for research and international affairs of the Faculty of International and Political Studies at the University of Lodz, Poland. He obtained M. Sc. in sociology (1991), Ph.D. in Social Sciences (1996), and D. Habilis in Social Sciences (2010), was a Soros FCO Scholar at Hertford College, Oxford University (1992-93), Fulbright Junior Scholar at Columbia University in the City of New York (1993-94); since 2011 associate professor at the Faculty of International and Political Studies, University of Lodz, Poland. In the years 2005 - 2009 the Head of the Center for Strategic Studies and Forecast at the Lodz School of International Studies, Poland. External Expert of National Forecast Program Poland 2020, expert at the Polish National Science Centre (NCN), Foreign Expert at the French CSFRS (Conseil Superieur de la Formation et de la Recherche Strategique), member of the Conseil Scientifique of M. Sc. Studies in criminology at the Conservatoire $\mathrm{N}$ ational des $\mathrm{A}$ rts et $\mathrm{M}$ étiers in Paris, expert and $\mathrm{M}$ ember of the A dvisory Board at the Countering Lone A ctor Terrorism(CLAT) network project coordinated by Institute for Strategic Dialogue in London (2015 - 16), consultant of the Police force in Lodz, including SWAT Team in the City of Lodz (SPAP Lodz). Specializes in terrorism and security studies, transatlantic relations, problems of globalization, author of three books and more than 50 scientific articles, chapters and reviews on these issues. 


\title{
BOOK REVIEW
}

\section{Fawaz A. G erges, 2016. ISIS. A History, Princeton University Press, USA, 368 pages, ISBN : 978-0-691-17000-8}

\author{
Mihai M urariu \\ Research Associate, Faculty of Political Science, Philosophy and Communication, \\ West University of Timișoara \\ Timişoara/Romania \\ mihai.murariu@e-uvt.ro
}

In the summer of 2014, the movement known as Islamic State seemed to appear almost out of nowhere, exploding onto the centre of both Iraqi and Syrian politics. With their enemies often fleeing in disarray before the inferior numbers but highly motivated cadres of the movement, images of the black flag triumphant were witnessed by many millions around the world and also by the millions on the ground who found themselves under its rule. Yet its presence and triumph were no quirks of history, but rather symptomatic of a malaise with deep roots in the geopolitics of the Middle East, debates over what role Islam should have in modern society, and, perhaps most importantly, the capacity of radical ideas to inspire generations of men and women to die or kill in their names.

In his book, ISIS. A History, Fawaz A. Gerges has taken up a challenging task. Throughout its pages, he seeks to bring this task to a successful resolution through an approach which, while still concentrated in form, manages to point to the many sides of the rise and expansion of Islamic State. The book itself is organized into eight chapters, ranging from the worldview of ISIS and that of its founders, the nature of Iraqi politics, the interaction between Baathists and jihadists and, lastly, the role of the Arab uprisings and the Syrian Civil War in 
influencing the movement, complete with its struggle against Al Qaeda for the leadership of the great jihad against both the near enemy and the far enemy. Significantly, Gerges dedicates his work to the courage and resilience of Yazidi women, who have suffered the most from the atrocities perpetrated by Islamic State.

The first chapter, looking at the worldview of Islamic State, points from the onset to the fundamental importance of ideology, "a superglue that binds Salafi jihadist activists and combatants to each other and allows the movement to renew and revitalize itself after suffering setbacks" (p. 23). It is this binding power that makes it so dangerous, particularly as it has grown ever more sophisticated, with its rituals and theorists working to prove their coming victory in a grand struggle (p.23). Gerges links Abrahamic fundamentalism to a series of factors, such as "dualism (absolute evaluations of good versus evil), authority (of a sacred book or leader), selectivity (choosing certain beliefs or practices over others), and millennialism (confidence in eschatology as God's will)" (p.25). Yet the key point here is the presence of hostility towards secular modernity, directed towards all groups who are not part of the "true believer" core group. In the author's inspired turn of phrase, "the world according to ISIS is frozen in time and space", as it seeks to incorporate the laws of $7^{\text {th }}$ century Arabia into $21^{\text {st }}$ century societies (p.26). Moreover, for at least some of the men who lead the movement onto the path of struggle, this is necessary since it is meant to bring about the time of the Mahdi ("The Rightly Guided One"), the key figure in Islamic eschatological traditions, whose presence is meant to bring about an era of universal justice. The author makes a good job in portraying the influential Salafi-jihadist manifestos, such The M anagement of Savagery (Abu Bakr al-Najji), Introduction to the Jurisprudence of Jihad by Abu Abdullah al-Muhajjer and The Essentials of M aking Ready [for Jihad] by Sayyid Imam al-Sharif (Abdel-Qader Ibn Abdel-Aziz). In this, he is right to point out that, while most authors choose to focus on The M anagement of Savagery, the other two works are also important for dealing with the subject.

In rightly placing the initial - and arguably most important - focus on the ideological dimension, Gerges also points to the impact of the personalities involved in the development of what he calls the "totalitarian-religious 
movement" (p.29) that is Islamic State. From the figure of Abu Musab alZarqawi, an individual belonging to a "new wave of Salafi-jihadists who are obsessed with identity politics and the struggle to purify Islam and Islamic lands of apostasy" (p.82), to the rivalry between Abu Mohammed al-Joulani and Abu Bakr al-Baghdadi (whose evolution is detailed in the fourth chapter) in their conduct of the jihad in the Levant, the second chapter paints a clear picture of the mixture of deeply held beliefs mixed with human material desires that is often at the heart of Salafi-Jihadist politics. Over and over, Gerges shows the important impact which prison life had on such figures and how it ultimately intensified their willingness to use violence, as well as the sense of urgency with which they pursued their goals. It remains relevant in tracing the evolution of Al Qaeda in Iraq into what would eventually become Islamic State.

Perhaps most importantly for his overall vision, Gerges sees the destruction of Iraqi state structure in the wake of the American-led invasion of 2003 as the primary reason for the revival of Islamic State, which he describes in the third chapter. He argues that out of all the factors which led to the later resurgence of the Jihadist movement the single most important was "the inability of the coalition and the Iraqi political establishment to put forward an inclusive national project and rebuild the political landscape" (p.117). One other crucial aspect - which Gerges turns to in the fifth chapter - is the importance of the alliance between the Baathist remnants and the jihadists. He consistently places himself against the narrative that it was the Baathists who took over the jihadist movement, revolutionised its military capabilities and ensured its control of the population, especially since the narrative itself had been disseminated by other Islamist rivals, such as the movement once known as Jabhat al-Nusra (currently known as Hayyat Tahrir al-Sham). Instead, Gerges argues that it was the Baathists themselves who had already been Islamized and then essentially converted to the Salafi-jihadist worldview, an ideological transformation which only intensified after the invasion, in the context of the armed resistance which followed (pp.142-143). At the same time, Islamic State would not balk at arresting and killing its former Baathist and nationalist allies, for instance after the conquest of Mosul (p.128). Nevertheless, it was the imposition of a 
professionalised military structure by al-Baghdadi which enabled Islamic State to survive the combined blows of the United States and Iraq.

The sixth chapter of the book shows how, along with the dysfunctional Iraqi system, the Syrian Civil War as essential for the movement's expansion, even as it led to its final, violent split from al-Nusra. It also reiterates how its regeneration was greatly aided by its ideological cohesiveness and certainty. In this respect, the Jihadist belief in both the justness of the cause and its inevitable final victory can form a powerful combination: "[...] Salafi-Jihadists have a different take on time not measure success in months or years but rather in decades. Loss and suffering are seen as God's will to test the faith, endurance, and conviction of the mujahideen. The road to salvation runs through trial, sweat, blood, and pain. The greater the sacrifice, the greater God's rewards would be" (p.147). Indeed, as Gerges rightly points out, the greatest strength of Islamic State has been its adaptability and its synergy between ideology and praxis, which allowed it to monopolize the identity narrative of delivering the Sunni community from Shia domination (p.194). Lastly, Islamic State managed what no other jihadist group could, dissolving the borders between two states and using this gesture to reaffirm the strength of a pan-Sunni identity over national ones.

The final chapters focus on the way in which the Jihadists managed to infiltrate and take over the energies of the Arab uprisings, which bin Laden had interpreted as struggles between the Islamic community and world atheism (A)kufr al-'alami), part of the greater conflict between the West and Islamdom (p.205). Being willing to take the battle even to the mainstream Islamists such as the once powerful Muslim Brotherhood (Ikhwan) of Egypt, the Salafi-Jihadists can also argue that it is their pursuit of God's Sovereignty (H akyimiyya) and their ability to assert themselves through military means that proves them right, rather than any participation in democratic systems. The pursuit of Hakyimiyya thus becomes a struggle against the Qutbian inspired Jahiliyya (ignorance of the true path), ignorance which encompasses every political system based on man's laws, rather than divine commandments (pp. 216-217). The final chapter serves to reinforce the importance of this utopian notion that lies at the heart of SalafiJihadism as a whole, and which includes both Al Qaeda and Islamic State. 
Defining Islamic State as a youth movement at its core, Gerges argues that, in the case of Muslims living in the West, its allure can be explained by the fact that it offers its recruits a greater purpose in life, which is to be part of a grand historical mission of restoring Islamic unity (p.229).

One may invoke a number of limitations to the way in which the book reaches certain conclusions. For instance, the author points very briefly to the role played by earlier iterations of radical political Islam. The role of Sayyid Qutb, populariser of the Hakyimiyya-Jahiliyya division in the early-mid $20^{\text {th }}$ century, could have been expanded upon, as could have the historical role of Wahhabism and the similar patterns encountered in premodern Islamic eschatological movements, such as North-African Mahdism. In spite of such shortcomings, the book never truly falters in its relentless pursuit of the subject matter.

Islamic State is now facing swift territorial collapse in both Syria and Iraq. Yet, just as before, when the movement appeared crushed and held no important territory, one should never underestimate the openings for a future revitalisation. In this and other aspects concerning Islamic State, the book makes for an essential reading on a movement and phenomenon representing one of the key challenges facing $21^{\text {st }}$ century modernity. 


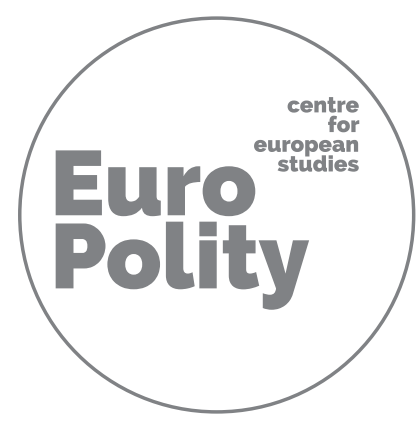




\title{
CALL FOR PAPERS
}

\section{Europolity - Continuity and Change in European Governance Vol. 12, no. 1 (2018)}

\author{
Place of publication \\ Romania \\ Type of publication \\ Publication date \\ Online and print \\ Published \\ June 2018 \\ C.H. Beck (Romania) Publishing House
}

ISSN

Online 2344-2255; Print 2344-2247

\section{Topics}

Europolity is a leading international journal for publication of new ideas, research results and fundamental advances in all aspects of International Relations, European Studies and Political Science. Europolity publishes well developed innovative articles, in English, and encourages emerging researchers to share their professional and academic knowledge. Contributions regarding international relations, European studies, political science, security studies and other related fields are strongly encouraged.

\section{Deadlines}

Authors should send their abstracts (200-250 words) to contact@europolity.eu before 15

M arch 2018. Early submissions are strongly encouraged.

Applicants will be informed about selection until $30 \mathrm{M}$ arch 2018.

The deadline for paper submission is $30 \mathrm{~A}$ pril 2018.

\section{Editorial Policies and G uidelines for Contributors}

Manuscripts should be written in English and they have to comply with the editing requirements of the journal, as presented in the Paper 
Template available on the journal's webpage. Only articles following these style rules will be taken into consideration for publication.

Publishing an article in Europolity is free of charge. Authors should ensure that their submissions are original contributions and should not be under consideration for any other publication at the same time. All submitted articles are subject to a rigorous peer review process, based on initial editor screening and double-blind refereeing by a minimum of two reviewers.

Full guidelines for the presentation of the papers and more details about the editorial policy of the journal are available at the editorial policy section from the website (http:// europolity.eu).

\section{Other details}

Abstracts should be in Word format with the following information and in this order: a) author(s), b) affiliation, c) email address, d) title of abstract, e) body of abstract, f) up to 6 keywords.

E-mails should be entitled: Europolity vol. 11, no. 1 - abstract author(s) name(s).

Please use plain text (Times Roman 12) and abstain from using footnotes and any special formatting, characters or emphasis (such as bold, italics or underline). Please note that the printed edition is planned for the beginning of June 2017. We acknowledge receipt and answer to all paper proposals submitted.

\section{Book Reviews}

We are also looking for reviews of books published between 2013-2017 dealing with developments in the fields of Political Science, International Relations Theory and European Studies. Reviewers must have their own copy of the book. Book reviews should have 1,000 - 1,500 words and should not only present the book, but also critically discuss the main issues it raises. Deadline for book reviews submission is 30 April 2018.

Further inquiries should be sent to the editorial board at contact@europolity.eu 


\section{CENTRE FOR EUROPEAN STUDIES}

The Centre for European Studies (CES), established by Government Decision N 0. 1082/2003 is a teaching and academic research structure within the Department of International Relations and European Integration (DIREI) of the $\mathrm{N}$ ational U niversity of Political Studies and Public A dministration (NUPSPA).

CES promotes education and professional training in the European Studies and International Relations field, contributing with its research projects, analysis and evaluations to a better understanding of the functioning and evolution of the processes and dynamics of world politics. CES supports in-depth innovative investigations of the European and international polity, politics and policies, stimulating debate and facilitating academic networking of scholars interested in these topics. The members and volunteers of CES prepare analytical research papers, offer consultancy on diverse European and international themes, organise and participate in national and international programs and projects aimed at promoting cooperation and information dissemination in these educational and research areas. The sustained and comprehensive dialogue and debates on various aspects regarding the complex dynamics on the international arena are promoted by CES through conferences and seminars and the resulted expertise is extremely useful not only for researchers and the academic field but it is also significant for the civil society, Romanian national institutions contributing in the end to a better understanding of the current international system. With the Master's programmes it promotes, viewed in the wider context of all the other educational programmes of DIREI and together with the analysis of different International and European aspects, the expertise offered in the end by CES is able to respond to the practical needs of the Romanian society, economy and administration, being thus a way of improving them, contributing also to an actual construction of identities at a European level. CES brings together at different debates researchers (know-how providers) and actors involved in public policies who represent the main beneficiaries, in order to raise the quality standard of the domestic input in the process of analysis and policy-making at national, European and international level. Thus, CES is trying to illustrate how enhancing the academic, theoretical research is useful in the practical policy-making process and how important is to have national experts trained in undertaking research in the European and international studies field. At a national level, CES cooperates with Romanian state institutions, public administration, private sector, NGO`s in organizing various seminars and debates which promote the European participatory democracy in action and European social values contributing to a deepening of the European integration process and being a valuable instrument for the global affirmation of the significance of the European Union in a broader context of International Relations.

Initially, the strategic mission of CES was to contribute to improving the teaching supply at post-graduate level for those willing to form or deepen their professional training in the area of European studies in the context of Romania's increasing efforts to complete the accession negotiations, and thereafter to smoothly and effectively adapt and work within the institutional and political system of the European Union. Therefore, since it was established, the Centre for European Studies contributed to the expansion of the educational offer of the Department of International Relations and European Integration by initiating the "European Politics and Economics" Master's Programme, developed in a new modular format involving training for both general and specialized competencies concerning the intersection of analysis and dissemination of theories of European integration and public policy. In this regard, the program succeeded in co-opting some important names of scientists from the academia of Bucharest; one can refer here to professors as Daniel Dăianu, Iordan Bărbulescu, George Voicu and Liviu Voinea. The syllabus included for the first time the area and the policies of the migration phenomena in the context of EU enlargement, border security and asymmetric risks/threats in the wider neighbourhood.

In 2010, a second master's project was implemented. Called „Evaluation of European Public Policies and Programmes”, this project was dedicated to a niche specialization absent from the Romanian labour market, but much needed, given the procedural requirements regarding the consistent application of the structural funding projects. In the same year, CES has initiated the first MA programme in English, "Security and Diplomacy", where the involved professors have both a recognized university career and a significant public activity: Ioan Mircea Paşcu (MEP, Vice-president of the European Parliament), Vasile Secăreş (NUPSPA founding rector, former head of the Presidential Administration), gen. Mihail Ionescu (Director of the Institute for Political Studies of Defense and Military History / Director of the Institute for Studies of Holocaust Elie Wiesel), Bogdan Aurescu (former Minister of Foreign Affairs), Constantin Buchet (CNCSAS Secretary), George Anglițoiu (Adviser on lobby and communication to the President of the Competition Council), etc. A new master's programme in English on 
Development, International Cooperation and Humanitarian Aid was launched starting with the academic year 20132014; one year later, it was followed by a new Master in Romanian on Social Economy.

Since 2012, CES is also a partner of the Romanian A ssociation of International Relations and European Studies (ARRISE), Romania's representative in ECSA World, to edit/permanently coordinate the publication of RoJIRES - The Romanian Journal of International Relations and European Studies. Moreover, CES started to edit a new series of the academic journal Europolity - Continuity and Change in European Governance, a biannual peer reviewed open access international academic journal. Designed in 2007, Europolity was primarily addressed to young researchers, giving them the opportunity to publish academic papers and opinion articles on topics related to European Union study. Nowadays, edited by CES, Europolity is mainly oriented towards multi-disciplinary scholarly work in European Studies, supporting therefore relevant theoretical, methodological and empirical analyses connected to this field and coming from EU Studies or International Relations, but also from International (Political) Economy, Law, Sociological Studies, Cultural Studies, etc.

CES supports excellence in academic research, the development of partnerships, and it tries to increase the visibility for its research and analysis results. The academic staff members have conducted research projects with impact and had a number of publications in this field. CES has collaborations with other prestigious research institutions abroad such as the Jean Monnet Chair within the Political Science Department of the Complutense University (Madrid), the European Institute of the London School of Economics, and the Romanian-based Altiero Spinelli Center of the Babes-Boylai in Cluj-Napoca. Between 2014 and 2017, DIREI and CES are hosting a Jean Monnet Chair focused towards "Bringing European Studies to Journalism, Agriculture, Engineering, Philology, Economics, History, Law and Sociology students", chaired by prof. Iordan Bărbulescu. Moreover, as a staunch promoter of European integration, CES is overseeing the implementation of two Jean Monnet projects aimed at supporting innovation and the spread of European Union related content within the time frame September 2015 August 2018. Firstly, the Jean Monnet Centre of Excellence In and O ut: U nderstanding the European U nion beyond its Borders intends to develop border management trainings for frontier workers from Romania, Republic of Moldova and Ukraine, as a means to improve knowledge and practices on European policies, in particular those related to border management and security. Secondly, the Jean Monnet Module EU*RO M edia. European Standards, Romanian A pplication: The M edia Roadmap for Romania's EU Council Presidency is designed to contribute to the Europeanization of the public sphere which must better understand the direct and indirect implications of the EU's impact on the member states and, last but not least, the importance of Romania holding the EU Council Presidency in the second half of 2019 and the potential contributions of the public sphere to the agenda-setting.

Finally, CES also manages research grants for the complex and interdisciplinary field of International Relations and European Studies. For example, in the period 2012-2015, CES monitors the implementation of five exploratory research projects - "Romania-Russia bilateral relationship: national and European perspective", "Implementation of the social market economy in Romania as a way of Europeanizing the Romanian society," "Operationalizing an evaluation model for the institutionalization of forms and practices of the social market economy in Romania", "The European Union and the Latin America - an interregional analysis", "Citizens and MEPs: Representation, Legitimacy and Political Participation" -, while actively supporting the involvement of young researchers. From this point of view, an important aspect of the CES activity consists in collaborating with NUPSPA's undergraduate, post-graduate and PhD students; in this regard, since 2009, CES is working closely with the Academic Club of European Studies (CASE), organizing events and activities designed to foster excellence in European research issues. CASE aims to be a via media, but also a connection point between academia and public institutions that can influence Europeanization, which is why CES supports the work of this NGO perceived as the youth component or the nursery for future researchers.

Through all its activities, CES contributes to enhance the image of the Department of International Relations and European Integration as an important research and teaching academic actor. 
Polfy

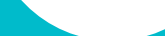




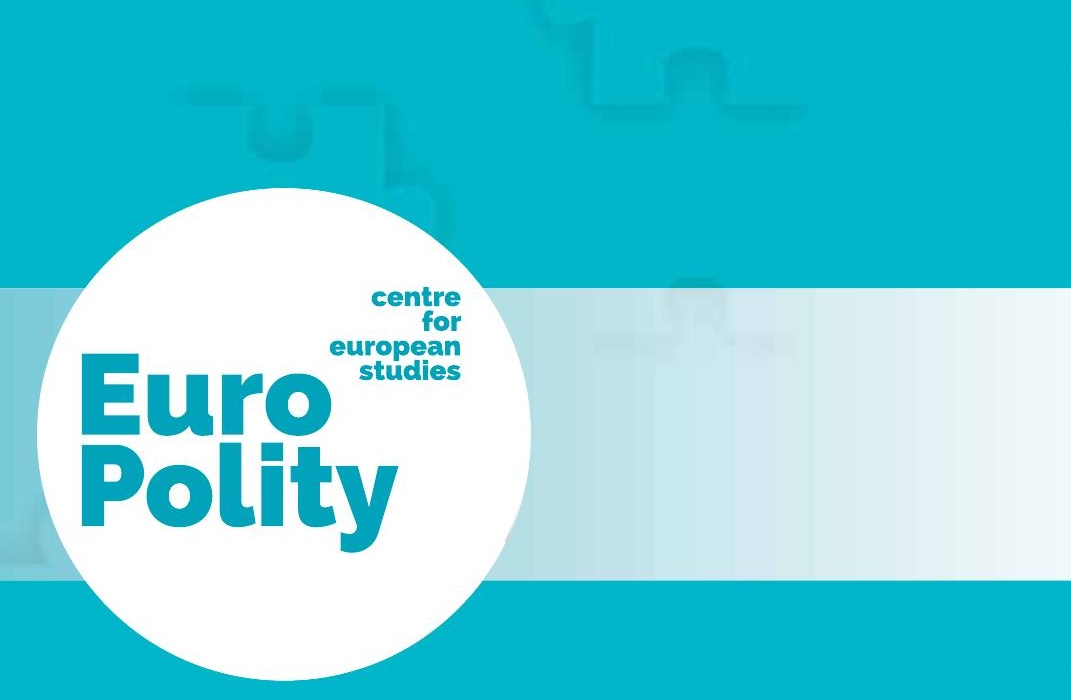

\section{Continuity and Change in European Governance}

30A Expoziției Bvd., Sector 1, Bucharest, Romania www.europolity.eu

ISSN print 2344-22247 | ISSN online 2344-2255 | ISSN-L 2344-2247 